The susceptibility of primordial germ cells to malignant transformation and isolation and characterization of members of a new gene family differentially expressed in invasive and noninvasive immortalized male germ cells

\author{
Dissertation \\ zur Erlangung des Doktorgrades \\ der Mathematisch-Naturwissenschaftlichen Fakultäten \\ der Georg-August-Universität zu Göttingen
}

vorgelegt von

Manal Bayomi Mahmoud Ahmed

aus El-Minia / Ägypten

Göttingen 2001 
D7

Referent: $\quad$ Prof. Dr. W. Engel

Korreferentin: Prof. Dr. S. Hoyer-Fender

Tag der mündlichen Prüfung: 29.01.2002 


\section{CONTENTS}

Page

ABBREVIATIONS

1.1 Testicular germ cell tumors

1.2 Transgenic mice as models for cell type specific malignant transformation

1.3 LTA transgenic mice as possible models to analyse the susceptibility of primordial germ cells to malignant transformation

1.4 Immortalized murine male germ cell lines as a possible in vitro system to study the process of malignant transformation in TGCT

2.5. Media, antibiotics and agar-plates

2.5.1.1 Media for bacteria

2.5.1.2 Cell culture media 
2.6. Bacterial strains, vectors, oligonucleotide, libraries, cell lines, animals and data bases

2.6.1 Bacterial strains

2.6.2 Vectors

2.6.3 Synthetic oligonucleotide primers 17

2.6.4 Libraries $\quad 18$

2.6.5 Eukaryotic cell lines $\quad 18$

2.6.6 Animals 19

2.6.7 Data bases 19

2.7. Molecular biological methods 20

2.7.1 Isolation of nucleic acids 20

2.7.1.1 Isolation of genomic DNA from tissue samples 20

2.7.1.2 Isolation of total RNA from tissue 20

2.7.1.3 Isolation of poly(A)-enriched RNA 20

2.7.1.4 Isolation of plasmid DNA 21

2.7.1.4.1 Small-scale isolation of plasmid DNA 21

2.7.1.4.2 Large-scale isolation of plasmid DNA 21

2.7.1.4.3 Isolation of DNA fragments from agarose gels 22

2.7.1.4.4 Isolation of DNA fragments from acrylamide gels 22

2.7.1.4.5 Determination of nucleic acid concentration 23

2.7.2 Enzymatic modifications of DNA 23

2.7.2.1 Restriction of DNA 23

2.7.2.2 Dephosphorylation of plasmid-DNA 23

2.7.2.3 Ligation of DNA fragments 24

2.7.2.4 Transformation of bacteria 24

2.7.2.5 TA-Cloning 25

2.7.2.6 Filling-up reaction 25

2.7.3 Gel electrophoresis 25

2.7.3.1 Agarose gel electrophoresis of DNA 25

2.7.3.2 Agarose gel electrophoresis of RNA 26 
2.7.4 Blotting techniques

2.7.4.1 Dot blotting of DNA to nitrocellulose filters

2.7.4.2 Southern blotting of DNA to nitrocellulose filters 27

2.7.4.3 Northern blotting of RNA to nitrocellulose filters 28

2.7.5 Labelling of nucleic acids $\quad 28$

2.7.5.1 „Random Prime“ method for generation of ${ }^{32} \mathrm{P}$ labelled DNA 28

2.7.5.2 Hybridization of nucleic acids 28

2.7.5.3 Hybridization of RZPD filters 29

2.7.5.4 Chromosomal localization $\quad 29$

2.7.6 Non-Radioactive dye terminator cycle sequencing 30

2.7.7 Methods of the "polymerase chain reaction" (PCR) 30

2.7.7.1 PCR of plasmid-DNA 30

2.7.7.2 Reverse transcriptase PCR (RT-PCR) 31

2.8. Cell biological methods

2.8.1 Transient transfection $\quad 32$

2.8.2 Harvesting of the cells 32

2.8.3 Luciferase assay 33

2.8.4 B-Gal assay 33

2.8.5 CAT-ELISA 33

2.8.6 Cellular localization of fusion proteins 34

2.8.7 Metaphase Arrest $\quad 35$

2.9. Procedure for making GCAP-LTA transgenic mice using zygote injection 35

2.9.1 Preparation of the DNA for the microinjection 35

3. RESULTS 36

3.1 GCAP-LTA transgenic mice 36 
3.1.1 Analysis of the human GCAP promoter region (in vitro)

3.1.1.1 Analysis of a $1.7 \mathrm{~kb}$ promoter fragment in seminoma (H12.1) and non-seminoma (1411HP) cell lines

3.1.1.2 Analysis of a $0.2 \mathrm{~kb}$ GCAP promoter fragment in different cell lines

3.1.1.3 Analysis of a 150-, 100- and 50 bp GCAP promoter fragment in a human embryonic carcinoma cell line (Tera-1)

3.1.2 Generation of GCAP-LTA transgenic mice

3.1.2.1 GCAP-LTA construct

3.1.2.2 Generation of transgenic mice

3.1.2.3 Genomic integration of the transgene

3.1.2.3.1 Analysis of transgenic founder mice (F0) generation

3.1.2.3.2 Analysis of the transgenic F1 generation

3.1.2.3.3 Analysis of the transgenic F2 generation

3.1.2.3.4 Analysis for homozygosity of the F3 generation

3.1.3 Expression analysis of LTA in transgenic mice

3.1.3.1 LTA expression in the adult testis of transgenic mice 48

3.1.3.2 LTA-Expression analysis during embryonic development $\quad 50$

3.2 Isolation of a cDNA of a new family of PHD-finger-like chromatin proteins (Pfcp) 51

3.3 Expression analysis of the mouse Pfcp and human PFCP gene

3.5.1 Genomic structure of Pfcp.1

3.5.2 Genomic structure of Pfcp.2

3.5.3 Genomic structure of Pfcp. 3 and Pfcp.4 
3.8 Cellular localization of a mouse Pfcp.1-GFP fusion protein in mammalian cells

3.9 Metaphase arrest

4. DISCUSSION

4.1 Summary of the results

4.3 Characterization and functional examination of mouse Pfcp, overexpressed in GC1spg cells

4.5 The homology between protein sequences of Pfcp in different species 


\section{ABBREVIATIONS}

BCP 1-bromo-3-chloropropane

BSA Bovine serum albumin

CAT Chloramphenical acetyltransferase

CBB Coomasie brilliant blue

cpm counts per minutes

DEPC Diethylpyrocarbonate

DNA Deoxyribonucleic acid

Dnase deoxyribonuclease

dNTP deoxynucleotidetriphosphate

DTT Dithiothreitol

EDTA Ethylene diamine tetraacetic acid

IPTG Isopropyl-ß-thiogalactopyranoside

NaAc Sodium acetate

NTP Nucleotide

PCR Polymerase chain reaction

RNA Ribonucleic acid

RNase Ribonuclease

SDS Sodium dodecylsulfate

SV40 Simian Virus 40

UV Ultra violet

X-Gal 5-bromo-4-chloro-3-indolyl- $\beta$-galactosidase 


\section{INTRODUCTION}

\subsection{Testicular germ cell tumors}

It is uncertain which developmental stage of spermatogenesis has the potential to malignant transformation, leading to germ cell neoplasia. In human, testicular germ cell tumors (TGCT) represent a unique type of human cancer from several different perspectives. Although TGCT comprise only $2 \%$ of all human malignancies, they do have their highest incidence in man between 20 and 34 years of age, indicating that the tumors initiate early in life. Over the past several decades, the incidence of TGCT has been steadily increasing in the Western world (Bergstrom et al., 1996). Several risk factors for TGCT development have been identified, which include cryptorchidism, spermatogenic or testicular dysgenesis and Klinefelter's syndrome (Tollerud et al., 1985). They arise from germ cells and exhibit rapid growth and early metastasis to lymph nodes and lungs. This cancer form represents one of the few tumor types that are curable by chemo- and radiotherapy, with an overall cure rate of about $80 \%$ (Einhorn, 1990). Overall, a 6 to 10-fold increase in risk for development of a GCT has been estimated for the first-degree male relative of an affected individual (Heimdal et al., 1993).

TGCT represent one of the few types of cancer that are curable by cisplatin-containing chemotherapy and, consistently, most TGCT cell lines display an unusually high sensitivity to cytotoxic agents (Masters et. al., 1993; Huddart et. al., 1995; Cresta et. al., 1996). It has been demonstrated that the product of the p53 tumour-suppressor gene plays a pivotal role in the sensitivity of tumour cells to chemotherapy- or radiation-induced apoptosis (Clarke et. al., 1993; Lowe et. al., 1993; Fisher, 1994; Harris, 1996).

TGCT display a diverse histology that is rarely found in other tumors. They can be subdivided into seminomas and non-seminomas. Seminomas do not display embryonic differentiation, whereas non-seminomas display embryonic differentiation and exhibit embryonal (embryonal carcinoma), extra-embryonal (choriocarcinoma, yolk sac tumor) and somatic (teratoma) patterns of tissue differentiation (Ulbright 1993; Motzer et al., 1998) (Fig. 1). The precursor of TGCT is the testicular carcinoma in situ (CIS), which progresses over a period of up to 10 years to an invasive malignancy (Skakkebaek 1972). 


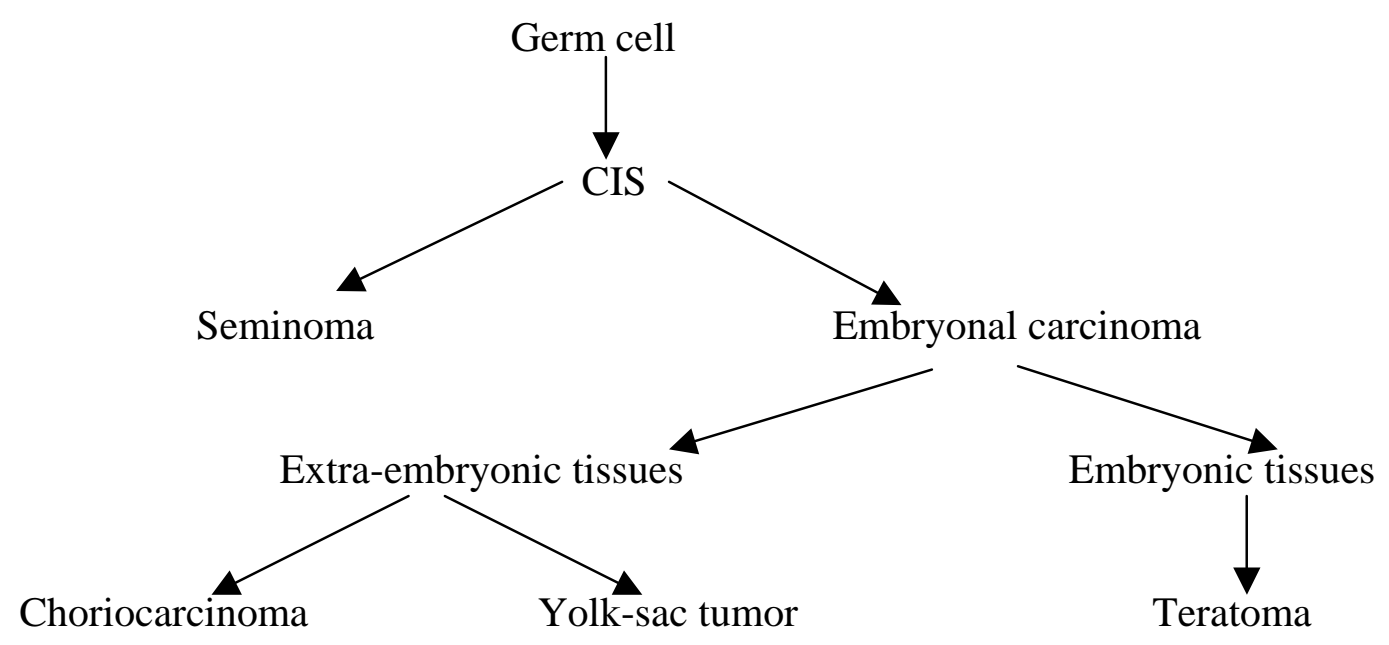

Fig.1 A model to explain the histogenesis of testicular neoplasms. Testicular germ cell neoplasms in humans originate from germ cells and progress through a pre-malignant carcinoma in situ (CIS) stage. CIS gives rise to both seminomas and nonseminoma (embryonal carcinoma) germ cell tumors. Embryonal carcinoma cells can differentiate into either extra-embryonic tissues (giving rise to choriocarcinomas or yolk sac tumors) or embryonic tissues (teratomas).

Cytogenetic and molecular genetic analysis of male germ cell tumors (GCTs) has yielded important data relevant to the understanding of the mechanism of germ cell (GC) transformation (Chaganti et al., 1996). Karyotypic analysis has identified a specific marker chromosome, isochromosome 12p, or i(12p), in male germ cell tumors (Vos et al., 1990). This abnormal chromosome, comprising two fused $\mathrm{p}$ arms from chromosome 12, is present in 80$90 \%$ of germ cell tumor samples, regardless of histology or site of metastatic disease (Bosl et al., 1994). i(12p) is also present in testicular CIS (Atkin et al., 1987), indicating that acquisition of $\mathrm{i}(12 \mathrm{p})$ is an early step in testicular germ cell tumorigenesis.

Loss of function of the tumor suppressor protein $\mathrm{RB}$ is a common event in the genesis of many human tumors. One parental allele of RB is lost by loss of heterozygosity (LOH) in approximately 30-39\% of testicular germ cell tumors (Strohmeyer et al., 1991 and Houldsworth et al., 1997). Mutations of the TP53 tumor suppressor gene, which encodes the p53 protein, occur in $~ 50 \%$ of common solid tumors, such as lung, breast and colon (Peng et al., 1993). The CCND2 gene, mapped at chromosome 12p13, may be the best candidate for the 12p driver gene (Houldsworth et al., 1997). Cyclin D2 is one of the D-type cyclins which, along with the cyclin-dependent kinases (cdks) cdk4 and/or cdk6, regulate the phosphorylation of $\mathrm{pRB}$ and control the $\mathrm{G}_{1}-\mathrm{S}$ cell cycle checkpoint. Disruption of this 
checkpoint through amplification / overexpression of D-type cyclins is known to be one of the important pathways in human tumor development (Weinberg 1995). Cyclin D2 is expressed by murine day 7 to day 13 (postnatal) testicular spermatogonia, suggesting that this cyclin may normally regulate spermatogonial mitotic $\mathrm{G}_{1}-\mathrm{S}$ transition in the postnatal testis (Nakayama et al., 1996). In an immunohistochemical analysis of paraffin embedded tissue sections, GCs in the normal testis showed occasional cyclin D2-positive spermatogonia, whereas the majority of aberrant GCs in the CIS lesion expressed cyclin D2. In tumor specimens, seminomas (SEs) expressed cyclin D2, whereas embryonal carcinomas (ECs) exhibited more focal, predominantly nuclear expression of cyclin D2. Among teratomas (TEs) cyclin D2 expression appeared to correlate with a particular pathway of somatic differentiation. These data suggested that cyclin D2 expression may be an early event in GCT development with a subsequent down-regulation in certain lineages of differentiation (Houldsworth et al., 1997).

Although the CIS cell is generally regarded as the precursor of all adult male GCTs, the target stage of GC development at which transformation occurs is not known. Two models of origin of CIS cells have been put forward. One was proposed by Skakkebaek et al. (1987) and Skakkebaek et al. (1998). This model suggested that fetal gonocytes, which have escaped normal development into spermatogonia, may undergo abnormal cell division mediated by a kit receptor/stem cell factor (SCF) paracrine loop, leading to the origin of CIS cells. The kit receptor is normally expressed by GCs during the first trimester and postnatally during meiosis, whereas SCF is expressed by the Sertoli cells (Loveland et al., 1997). Gonocytes derailed in their normal development have been postulated to be susceptible to subsequent invasive growth through the mediation of postnatal and pubertal gonadotrophin stimulation. This hypothesis is based mainly on a consideration of immunophenotypic markers expressed by gonocytes and CIS cells, types of abnormal germ cells seen in developmental disorders that predispose to germ cell tumors, and epidemiology of GCT incidence (Skakkebaek et al., 1998).

A second model proposed by Chaganti et al. (2000) took into account four established genetic properties of GCTs, i.e., increased 12p copy number, expression of cyclin D2 in CIS, consistent near triploid-tetraploid chromosome numbers, and abundant expression of wildtype p53 (Chaganti et al., 1998). Chaganti et al. (2000) have postulated that the most likely target cell for transformation during GC development may be one with replicated chromosomes that expresses wild-type p53, harbors DNA breaks, and may be prone to 
apoptosis. Such a stage is represented by the zygotene-pachytene spermatocyte, at which a "recombination checkpoint" appears to operate, which can provide an apoptotic trigger in the presence of unresolved DNA double-strand breaks. This stage is temporally the longest phase during spermatogenesis with the cell cycle machinery halted to permit recombinational events to complete. It also contains replicated DNA, and based on murine data, wild-type p53 protein is temporally expressed at this stage (Schwartz et al., 1999). According to this model, aberrant chromatid exchange events associated with crossing-over during zygotene-pachytene may lead to increased $12 p$ copy number and overexpression of cyclin D2. Such a cell may escape recombination checkpoint-associated apoptotic response through the oncogenic effect of cyclin D2, leading to aberrant reinitiation of the cell cycle and genomic instability (Fig. 2) (Chaganti et al., 1998).

However, at present it is not possible to determine the exact developmental stage of origin of germ cells giving rise to CIS. Illuminating this phenomenon would greatly enhance our knowledge on the molecular mechanisms of the transformation process of TGCT.

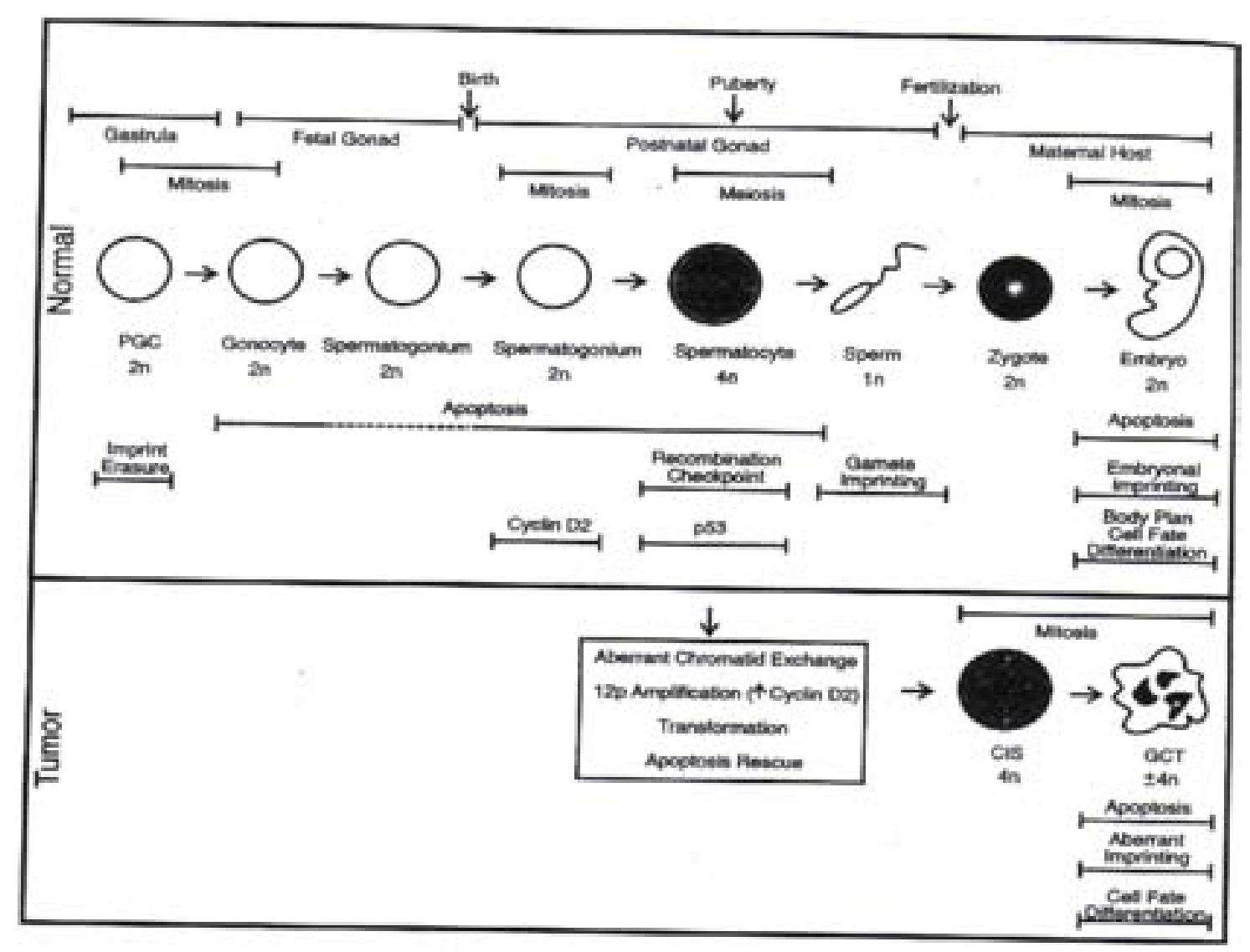

Fig. 2 A diagrammatic representation of male GC development during a normal life span and the proposed model of GC transformation (Chaganti et al., 2000). The key genetic events that underline normal male GC fate 
and embryonal development are shown with respect to their spatial and temporal relationships. GCT development is depicted in the context of normal GC biology as discussed in the text.

\subsection{Transgenic mice as models for cell type specific malignant transformation}

Oncogenesis seems to be related to the efficacy of the immune response and the presence of large-T antigen on the cell surface as well as in the nucleus (Hargis et al., 1979; Abramczuk et al., 1984 and Lewis et al., 1985). Large-T antigen is of a class of oncogenes that can both, immortalize primary cells and release (or transform) cultured cells from their normal growth controls, such as contact inhibition and dependence on serum growth factors. Yet, in vivo SV40 virus will produce tumours in mice only after a long latent period (Tooze, 1981).

Hanahan (1985) used recombinant genes composed of the upstream region of the rat insulin II gene linked to sequences coding for the large-T antigen of simian virus 40 for transferring into fertilized mouse eggs. Large-T antigen was detected exclusively in the $\beta$-cells of the endocrine pancreas of these transgenic mice. The $\alpha$-and $\beta$-cells normally found in the islets of Langerhans were rare and disordered. Well-vascularized $\beta$-cell tumours arose in mice harbouring and inheriting these hybrid oncogene.

Further ectopic expression of large-T antigen gene in transgenic mice under control of tissue specific promoters was reported by Behringer et al. (1988). They generated transgenic mice lines harboring SV40 large T antigen under the control of mouse Protamin 1- promoter which was expressed in spermatids. The LTA expression was detected by day 25 during testicular development. No tumor was detected in the testis of these transgenic mice.

To determine the oncogenic potential of SV40 large-T antigen in haploid germ cells, the rat proacrosin (prACRII-LTA) fusion gene was constructed and tested for activity in transgenic mice by Nayernia et al. (1998). This fusion gene is transcribed at the first time in pachytene spermatocytes and proacrosin-LTA fusion mRNA is translated in spermatids. However, a LTA activity is also displayed in different tumours, which developed in advanced age in prACRII-LTA transgenic mice. But so far no TGCT developed in these transgenic mice. 


\subsection{LTA transgenic mice as possible models to analyse the susceptibility of primordial germ cells to malignant transformation}

Alkaline phosphatase (AP) is an ubiquitous membrane-bound glycoprotein that catalyzes the hydrolysis of phosphate monoesters at basic $\mathrm{pH}$ values. The enzyme is present in all species from bacteria to humans, suggesting that AP plays a fundamental biological role. Human AP is encoded by a multigene family composed of four loci. These genes can be classified according to their restricted or ubiquitous expression (Van Hoof et. al., 1994). Three tissuespecific expressed alkaline phosphatase (TSAP) genes, i.e. germ cell alkaline phosphatase (GCAP), placental alkaline phosphatase (PLAP) and intestinal alkaline phosphatase (IAP) are located on chromosome 2q34-q37, whereas the ubiquitiously expressed liver/bone/kidneytype AP gene (TNAP) is located at chromosome 1p26.1-p34 (Millan et. al., 1995) .

To examine the susceptibility of primordial germ cells (PGCs) to malignant transformation in an in vivo system, we generated transgenic mouse lines harboring the coding sequence $(2.7$ $\mathrm{kb}$ ) of simian virus 40 (SV40) large tumor antigen (TAg) linked to $1.7 \mathrm{~kb}$ of the human germ cell alkaline phosphatase (GCAP) promoter region. GCAP is expressed by primordial germ cells during their migration through the genital ridge. It is also known that GCAP expression accompanies the first steps of germ cell maturation in normal adult testis. Furthermore, trace amounts of the isoenzyme are found in the thymus (Millan, 1992).

Moreover GCAP has been proven to be a reliable marker for testicular seminomas and has been suggested as a marker to recognize precancerous stages of testicular germ cell tumors (Millan et. al., 1995; Mann, 1990; Koshida et. al., 1991). It was shown that GCAP expression depends on the degree of differentiation of testicular tumors (Schär et. al., 1997). Three independent GCAP-LTA transgenic lines were generated in this thesis and analysed for LTA expression and tumor development.

\subsection{Immortalized murine male germ cell lines as a possible in vitro system to study the process of malignant transformation in TGCT}

In the past decade immortalized murine male germ cells representing different developmental stages of spermatogenesis have been established, using the "immortalizing" properties of the SV40 large $\mathrm{T}$ antigen. These cell lines facilitate the ability to investigate the field of 
spermatogenesis since working with primary cultures is limited by the fact that the cells are seldom functional after 15 days. One of these immortalized germ cell lines, GC-1spg, was characterized as a germ cell line arrested between the differentiation stage of spermatogonia type B and primary spermatocytes (Hofmann et al., 1992). A second immortalized germ cell line termed GC-4spc has been characterized as a germ cell line arrested between the preleptotene spermatocyte and the early pachytene spermatocyte (Tascou et al., 2000). The spermatogonia-derived cell line GC-1spg and the spermatocyte-derived cell line GC-4spc were evaluated with respect to their invasive potency and to their differences in gene expression: an in vitro Matrigel invasion assay revealed a significantly higher invasive potential of GC-1spg cells as compared to GC-4spc cells and using a suppression subtractive hybridization on RNA of invasive GC-1spg cells and non-invasive GC-4spc cells several genes upregulated in GC-1spg were identified (Tascou et al., 2000).

Taken together, both the enhanced invasive activity of GC-1spg cells and the upregulated expression of genes known to be involved in the process of tumor progression suggest that the immortalized spermatogonia-derived cell line GC-1spg does have a higher potential to malignant transformation than the immortalized spermatocyte-derived cell line GC-4spc. From those cDNAs upregulated in GC-1spg cells that were unknown till now, one was studied in more detail in this thesis. We named this gene Pfcp (PHD-finger-like chromatin protein) as its deduced protein sequence shows a domain known to be involved in chromatin binding. We show that the mouse Pfcp gene belongs to a gene family and describe its expression pattern, genomic structure, chromosomal localization and cellular localization in inter- and metaphase stages of the cell cycle. 


\section{MATERIALS AND METHODS}

\subsection{Chemicals}

Acrylamide

Agar

Agarose

Ampicillin

Ampuwa

Bacto-Tryptone

Bacto-Yeast-Extract

Bromphenolblue

BSA

Chloroform

Dextransulfate

Diethylpyrocarbonate (DEPC)

Dimethylsulfoxide (DMSO)

Dithiothreitol

DMEM

DNA Markers

DNase I (RNase-free)

dNTPs (100 mM)

Dye Terminator Mix

Ethanol

Ethidium bromide

Ficoll 400

FBS

Formaldehyde

Formamide

Geneclean-Kit

Glycerol
Serva, Heidelberg

Difco, Detroit, USA

Gibco/BRL, Karlsruhe

Sigma, Deisenhofen

Fresenius AG, Bad Homburg

Difco, Detroit, USA

Difco, Detroit, USA

Sigma, Deisenhofen

Biomol, Hamburg

Baker, Deventer, NL

Amersham, Freiburg

Sigma, Deisenhofen

Merck, Darmstadt

Sigma, Deisenhofen

Gibco/BRL

Gibco/BRL, Karlsruhe

Amersham, Freiburg

Boehringer, Mannheim

Applied Biosystems

Baker, Deventer, NL

Sigma, Deisenhofen

Amersham, Freiburg

Gibco/BRL, Karlsruhe

Gibco/BRL, Karlsruhe

Fluka, Neu Ulm

Dianova, Hamburg

Gibco/BRL, Karlsruhe 
IPTG

Jetsorb Gel Extraction Kit/300

Kanamycin

Klenow-DNA-Polymerase

B-Mercaptoethanol

Mineral oil

Orange-G

PBS

Phenol

Plasmid-Midi Kit

Phagen-Maxi Kit

Polyethylenglycol 6000

Proteinase K

Radioactive substances :

$\left(\alpha^{32} \mathrm{P}\right)$-dCTP, $\left(\Upsilon^{32} \mathrm{P}\right)$-dATP .

Rediprime ${ }^{\mathrm{TM}}$ II

Restriction enzymes

Reverse Transcriptase

RNase Inhibitor

RNA-Markers

Salmon DNA

SDS

Select Peptone

T4-DNA-Ligase

T4-DNA-Polymerase

Taq-DNA-Polymerase

Tris

t-RNA

Tween-20

X-Gal

Xylencyanol

Cell culture medium
Biomol, Hamburg

Genomed, Bad Oeynhausen

Sigma, Deisenhofen

Amersham, Braunschweig

Serva, Heidelberg

Sigma, Deisenhofen

Sigma, Deisenhofen

Gibco/BRL, Karlsruhe

Gibco/BRL, Karlsruhe

Qiagen, Hilden

Qiagen, Hilden

Serva, Heidelberg

Boehringer, Mannheim

Amersham, Braunschweig

Amersham, Freiburg

Gibco/BRL, Karlsruhe

Gibco/BRL, Karlsruhe

Boehringer, Mannheim

Gibco/BRL, Karlsruhe

Sigma, Deisenhofen

Serva, Heidelberg

Gibco/BRL, Karlsruhe

Boehringer, Mannheim

Boehringer, Mannheim

Amersham, Braunschweig

Sigma, Deisenhofen

Boehringer, Mannheim

Sigma, Deisenhofen

Biomol, Hamburg

Bio-Rad, München

Gibco/BRL, Karlsruhe;

Sigma, Deisenhofen 


\subsection{Materials}

Blotting papers GB-002/003

Filter paper 0858

Hybond $\mathrm{C}$ membrane

Hybond $\mathrm{N}$ membrane

Membrane filter

$\mathrm{NAP}^{\mathrm{TM}} 5$ Sepahdex G25-column

Nitrocellulose filter BA 85

Petri dishes

Pipette tips

Reaction tubes

Quarz-cuvettes

Radiographic films (Hyper film ${ }^{\mathrm{TM}}-\mathrm{MP}$ )

Ultra centrifuge tubes

Centrifuge tubes

Cell culture bottles
Schleicher \& Schüll, Dassel

Schleicher \& Schüll, Dassel

Amersham, Braunschweig

Amersham, Braunschweig

Millipore, Morlsheim

Amersham, Freiburg

Schleicher \& Schüll, Dassel

Greiner Nunc., Nürtingen

Eppendorf, Hamburg

Eppendorf, Hamburg

Hellma, Mühlheim

Amersham, Braunschweig

Beckmann, München

Beckmann, München

Greiner Nunc, Nürtingen

\subsection{Solutions and buffers}

Denaturing solution

$1.5 \mathrm{M} \mathrm{NaCl}$

$0.5 \mathrm{M} \mathrm{NaOH}$

Denhardt`s-solution (50x)

$1 \% \mathrm{BSA}$

$1 \%$ Polyvinylpyrrolidone

$1 \%$ Ficoll 400

in 20x SSC (PH 7.0)

dNTP-Mix (25 mM)

$100 \mathrm{mM}$ dATP

$100 \mathrm{mM}$ dGTP

$100 \mathrm{mM}$ dCTP

100 mM dTTP 
E-Buffer (10x)

Elutions buffer

Glycylglycin buffer

Hybridization solution I

Hybridization solution II

( for RZPD-Filter )

Hybridization buffer (5x)

LB-Agar pH 7.2

LB-Medium pH 7.2

Ligation buffer (10x)
$300 \mathrm{mM} \mathrm{NaH}_{2} \mathrm{PO}_{4} \mathrm{pH} 7.0$

50 mM EDTA

$1.5 \mathrm{M} \mathrm{NaCl}$

$20 \mathrm{mM}$ Tris- $\mathrm{HCl}$ (pH 7.5)

$1 \mathrm{mM}$ EDTA

25 mM Glycylglycin, pH 7.8

$15 \mathrm{mM} \mathrm{MgSO}_{4}$

4 mM EDTA

$12.5 \%$ Denhardt Solution

$5 \%$ Dextran sulfate

$0.25 \%$ SDS

$5 \%$ SSC

$7 \%$ SDS

$0.5 \mathrm{M} \mathrm{Na}_{2} \mathrm{PO}_{4}$-Buffer pH 7.2

$1 \mathrm{mM}$ EDTA

$1.5 \mathrm{M} \mathrm{NaCl}$

$50 \mathrm{mM}$ Tris- $\mathrm{HCl}$ (pH 7.5)

5 mM EDTA

LB-Medium with

$1.5 \%$ Bacto-Agar

$1 \%$ Bacto-Tryptone

$0.5 \%$ Bacto-Yeast-Extract

$1 \% \mathrm{NaCl}$

600 mM Tris-HCl (pH 7.5)

$80 \mathrm{mM} \mathrm{MgCl}_{2}$

$100 \mathrm{mM}$ DTT 
Loading buffer I

Loading buffer II

Luciferase buffer

Luciferin

Luciferin-solution

Lysis buffer

(for genomic DNA)

Microinjections buffer

Neutralization solution
$95 \%$ Formamide

$20 \mathrm{mM}$ EDTA

$0.05 \%$ Bromphenolblue

$0.05 \%$ Xylencyanol

$15 \%$ Ficoll 400

$200 \mathrm{mM}$ EDTA

$0.1 \%$ Orange $\mathrm{G}$

300 $\mu 1$ Glycylglycin buffer

$60 \mu 1$ 100mM P-phosphate, pH7.8

$4 \mu 1$ 100mM DTT

$4 \mu 1200 \mathrm{mM}$ ATP

55mg DTT, dissolved in

35,7ml Glycylglycin-Puffer, $\mathrm{pH} 7.8$

10mg Luciferin

stored at $-80^{\circ} \mathrm{C}$

$1 \mathrm{ml}$ Luciferin

4ml Glycylglycin-Puffer, pH 7.8

40 $\mu 1$ 1M DTT

50 mM Tris- $\mathrm{HCl} \mathrm{pH} 8.0$

$100 \mathrm{mM}$ EDTA

$0.5 \%$ SDS

10 mM Tris-HCl pH 7.4

$0.2 \mathrm{mM}$ EDTA

$1.5 \mathrm{M} \mathrm{NaCl}$

$1 \mathrm{M}$ Tris- $\mathrm{HCl}(\mathrm{pH} 7.0)$ 
PBS- Buffer

$130 \mathrm{mM} \mathrm{NaCl}$

$7 \mathrm{mM} \mathrm{Na}_{2} \mathrm{HPO}_{4}$

$4 \mathrm{mM} \mathrm{NaH}_{2} \mathrm{HPO}_{4}$

Salmon DNA

$100 \mu \mathrm{g} / \mathrm{ml}$

Solution E1

$50 \mathrm{mM}$ Tris/HCl pH 8.0

10 mM EDTA

$100 \mu \mathrm{g} / \mathrm{ml}$ RNase

Solution E2

$200 \mathrm{mM} \mathrm{NaOH}$

$1 \% \operatorname{SDS}$

Solution E3

3.1 M Potassium acetate $\mathrm{pH} 5.5$

Solution E4

$600 \mathrm{mM} \mathrm{NaCl}$

100 mM NaAc pH 5.0

$0.15 \%$ Triton X-100

Solution E5

$800 \mathrm{mM} \mathrm{NaCl}$

$100 \mathrm{mM}$ NaAc pH 5.0

Solution E6

$1.25 \mathrm{M} \mathrm{NaCl}$

100 mM Tris/HCl pH 8.5

$\operatorname{SSC}(20 x)$

$3 \mathrm{M} \mathrm{NaCl}$

$0.3 \mathrm{M}$ Tri-sodium citrate $\mathrm{pH} 7.0$

TAE-Buffer

$200 \mathrm{mM}$ Tris

$200 \mathrm{mM}$ Acetic acid

5 mM EDTA pH 8.0 
TBE-Buffer (5x)

445 mM Tris-HCl pH 8.0

$445 \mathrm{mM}$ Boric acid

10 mM EDTA

TE-Buffer

$10 \mathrm{mM}$ Tris- $\mathrm{HCl} \mathrm{pH} 8.0$

$1 \mathrm{mM}$ EDTA

Washing solution I

2x SSC

$0.1 \%$ SDS

Washing solution II

$0.2 \mathrm{xSC}$

Washing solution III

$40 \mathrm{mM} \mathrm{Na} 2 \mathrm{PO}_{4}$-Buffer $\mathrm{pH} 7.2$

( for RZPD-Filter )

$0.1 \%$ SDS

X-Gal solution

$20 \mathrm{mg} \mathrm{X-Gal/ml} \mathrm{(dissolved} \mathrm{in} \mathrm{N,}$

N-Dimethylformamide)

\subsection{Sterilization of solutions and equipments}

All solutions, that were not heat sensitive, were sterilized at $121^{\circ} \mathrm{C}, 10^{5}$ Pascal for $60 \mathrm{~min}$ in an autoclave (Webeco, Bad Schwartau). Heat sensitive solutions were filtered through a disposable sterile filter ( 0.2 to $0.45 \mu \mathrm{m}$ pore size). Plasticware was autoclaved, as above. Glassware was sterilized overnight in an oven at $220{ }^{\circ} \mathrm{C}$. 


\subsection{Media, antibiotics and agar-plates}

\subsubsection{Media for bacteria}

\section{LB-Medium :}

$$
\begin{aligned}
& 1 \% \text { Trypton } \\
& 0.5 \% \text { Yeast Extract } \\
& 0.5 \% \mathrm{NaCl} \\
& \text { ad } 1000 \mathrm{ml} \mathrm{H} 2 \mathrm{O} \\
& \text { pH } 7.0
\end{aligned}
$$

The LB-Medium was prepared with sterilized water, autoclaved and kept at $4{ }^{\circ} \mathrm{C}$.

\subsubsection{Cell culture media}

The media, antibiotics and sera used for the eucaryotic cell culture were ordered by Gibco BRL, Karlsruhe, or Sigma, Deisenhofen. The components were first prewarmed at $37^{\circ} \mathrm{C}$, then mixed at sterile conditions and stored at $4^{\circ} \mathrm{C}$. The following media were used :

RPMI - 1640

$$
\begin{aligned}
& \text { Supplemented with : } \\
& 100 \mu \mathrm{g} / \mathrm{ml} \text { Streptomycin } \\
& 100 \text { I.E./ml Penicillin } \\
& 10 \% \text { Fetal Calf Serum }
\end{aligned}
$$

McCoy`s 5a Medium

Supplemented with :

$100 \mu \mathrm{g} / \mathrm{ml}$ Streptomycin

100 I.E./ml Penicillin

$10 \%$ Fetal Calf Serum

DULBECCO`s MEM ( DMEM ) Supplemented with :

$$
\begin{aligned}
& 100 \mu \mathrm{g} / \mathrm{ml} \text { Streptomycin } \\
& 100 \text { I.E./ml Penicillin } \\
& 10 \% \text { Fetal Calf Serum } \\
& 2 \mathrm{mM} \text { L-Glutamin }
\end{aligned}
$$


For long term storage an aliquot of about 2-3 x $10^{6}$ cells was suspended in $1 \mathrm{ml}$ of freezing medium (Gibco, BRL) and frozen and kept in liquid nitrogen.

\subsubsection{Antibiotics}

Master solutions were prepared for the antibiotics ampicillin and kanamycin, sterile filtered and stored at $-20{ }^{\circ} \mathrm{C}$. The antibiotic needed in each case was added after the medium was autoclaved at a temperature lower than $55^{\circ} \mathrm{C}$.

$\begin{array}{ll}\text { Master Solution } & \text { Final Concentration } \\ \text { (dissolved in water) } & \end{array}$

Ampicillin $\quad 100 \mathrm{mg} / \mathrm{ml} \quad 100 \mu \mathrm{g} / \mathrm{ml}$

Kanamycin $\quad 25 \mathrm{mg} / \mathrm{ml} \quad 25 \mu \mathrm{g} / \mathrm{ml}$

\subsubsection{IPTG / X-Gal-plates}

For the production of IPTG / X-Gal-Plates (blue-white-selection) Ampicillin, IPTG and X$\mathrm{Gal}$ in appropriate concentrations were added to the $\mathrm{LB}$ agar $\left(55^{\circ} \mathrm{C}\right)$ and poured in petri dishes. The dishes were stored at $4{ }^{\circ} \mathrm{C}$.

Master Solution

X-Gal

IPTG
$2 \%$ dissolved in N.N.-Dimethylformamid $100 \mathrm{mM}$ dissolved in $\mathrm{H}_{2} \mathrm{O}$
Final Concentration

$0.0004 \%$

$1 \mathrm{mM}$ 
2.6. Bacterial strains, vectors, oligonucleotide, libraries, cell lines, animals and data bases.

\subsubsection{Bacterial strains}

$\begin{array}{ll}\text { E.coli BL-21 } & \text { Stratagene, La Jolla, USA } \\ \text { E.coli JM 109 } & \text { Promega, Wisconsin, } \\ \text { E.coli DH5 } \alpha & \text { Hanahan et al., 1985 }\end{array}$

\subsubsection{Vectors}

$\begin{array}{ll}\text { Lawrist } 7 & \text { RZPD , Berlin } \\ \text { pBK-CMV } & \text { Stratagene, La Jolla, USA } \\ \text { pBluescript II SK (-) } & \text { Stratagene, La Jolla, USA } \\ \text { pCMV-BGal } & \text { Clontech, Heidelberg } \\ \text { pGEM-T, pGEM-T Easy } & \text { Promega, Wisconsin, USA } \\ \text { pGL3-Control } & \text { Promega, Wisconsin, USA } \\ \text { pGL3-Basic } & \text { Promega, Wisconsin, USA } \\ \text { pCAT-Control } & \text { Promega, Wisconsin, USA } \\ \text { pCAT-Basic } & \text { Promega, Wisconsin, USA }\end{array}$

\subsubsection{Synthetic oligonucleotide primers}

The synthetic oligonucletide primers used in this study were obtained either from NAPS (Göttingen, Germany) or Roth (Karlsruhe, Germany) and dissolved in water to a final concentration of $100 \mathrm{pmol} / \mu 1$.
AP 200 F
5'- CAC ACA AGA CAC AGT GAG CAG -3'
AP 150 F
5'- GGA CCC CAG CCC CAG CCC AGC -3'
AP 100 F
5’- GTG GCT TCA GGT CAA GAG GCT -3'
AP 50 F
5'- CCA GGA CAC AGT TTT CCC TGA -3'
AP R
5'- GTC TGG AAG CAG TCG GAG AGC -3' 


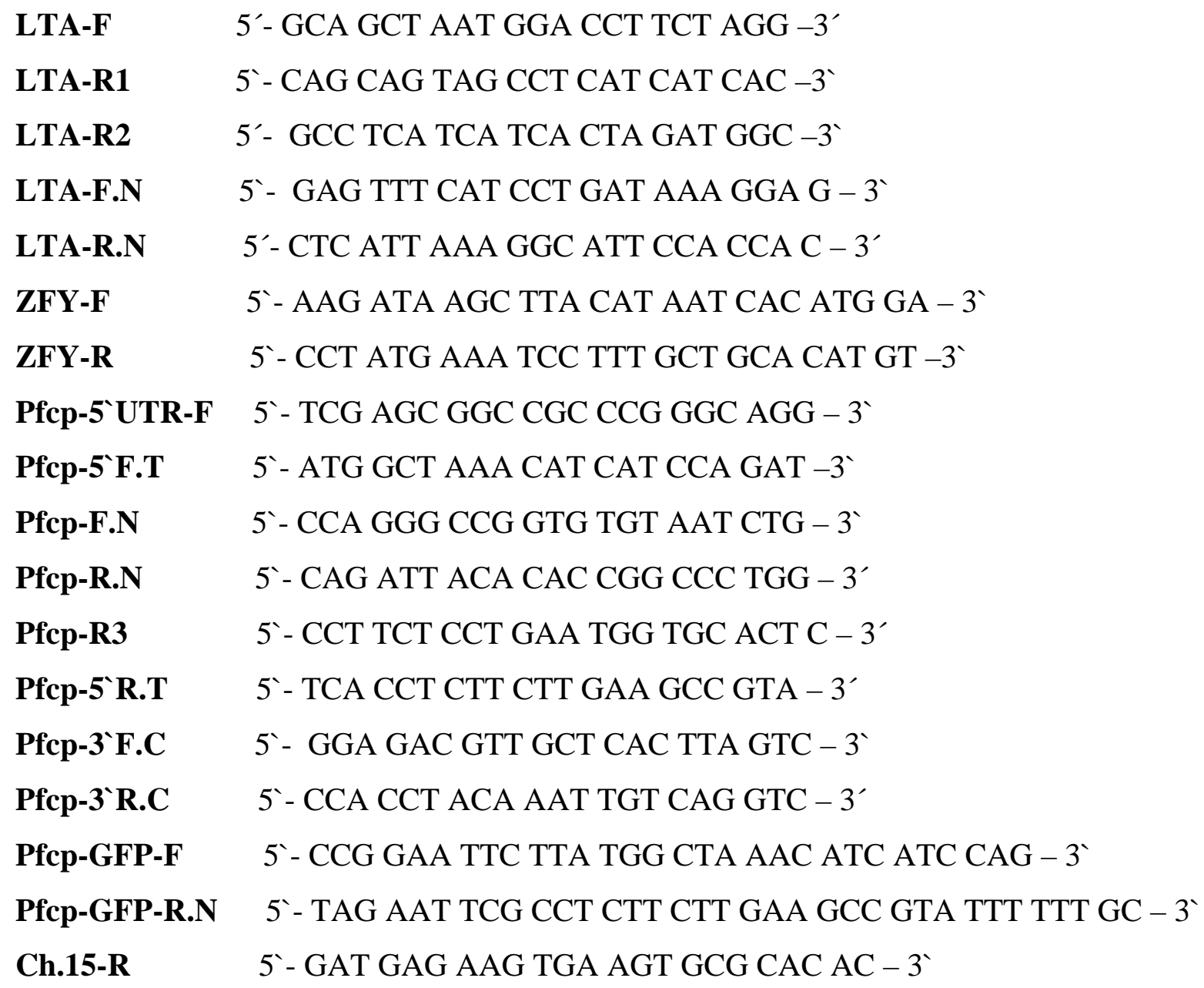

\subsubsection{Libraries}

Mouse genomic library ( RZPD, Berlin ) :

$\begin{array}{ll}\text { Vector : } & \text { Lawrist } 7 \\ \text { Bacteria : } & \text { E.coli DH5 } \alpha\end{array}$

\subsubsection{Eukaryotic cell lines}

H12.1 Seminoma and non-seminoma cell line, Prof.Dr.med.Schmoll, University of HalleWittenberg.

1411HP Non-seminoma cell line, Prof.Dr.med.Schmoll, University of Halle-Wittenberg.

Tera-1 Human embryonic carcinoma cell line, Beatrice et al., 1997, American Type Culture Collection (ATCC), Rockville, USA. 
F9 Mouse teratocarcinoma cell line, Sherman et al., 1976, American Type Culture Collection (ATCC), Rockville, USA.

NIH3T3 Embryonic mouse-fibroblasts, ATCC, Rockville, USA.

\subsubsection{Animals}

In this study, NMRI and FVB mice lines were used for both RNA and genomic DNA preparations. These mice are bred in the Institute of Human Genetics, Göttingen, Germany.

\subsubsection{Data bases}

Nucleotide and protein sequences were analysed with the data base sequence gene bank (http://www.ncbi.nlm.nih.gov) and EMBL (http://www.ebi.ac.uk) with the help of the BLAST-Programs (Altschul et al., 1990). Structural and functional motives of proteins were analysed with TMpred (http://dot.imgen.bcm.tmc.edu:931/seq-search/struc-predict.html), PSORT II (http://psort.nibb.ac. jp/psort/helpwww2.html) or Prosite (http://isrec.isbsib.ch/software/PFSCAN-form.html). 


\subsection{Molecular biological methods}

\subsubsection{Isolation of nucleic acids}

\subsubsection{Isolation of genomic DNA from tissue samples}

The method employed was the same as that of Laird et al. (1991). 1 to $2 \mathrm{~cm}$ of the tail from a mouse was incubated in $700 \mu \mathrm{l}$ of lysis buffer containing $35 \mu \mathrm{l}$ proteinase $\mathrm{K}(10 \mathrm{ug} / \mathrm{ul})$ at $55^{\circ} \mathrm{C}$ overnight. An equal volume of phenol was added, mixed by inverting, and centrifuged at $8000 \mathrm{xg}$ at room temperature for $10 \mathrm{~min}$. After transferring the aqueous layer into a new tube, the same procedure was repeated, but this time with 0.5 volumes of phenol and 0.5 volumes of chloroform. Then, the DNA was precipitated with 2.5 volumes of $100 \%$ ethanol, and fished-out with a pipette tip. Usually, the DNA was dissolved in 100-200 $\mu 1$ of 1 x TE buffer.

\subsubsection{Isolation of total RNA from tissue}

TRI Reagent is an improved version of the single-step method for total RNA isolation. The composition of TRI Reagent includes phenol and guanidine thiocyanate in a mono-phase solution. 100-200 mg tissue sample was homogenized in 1-2 $\mathrm{ml}$ of TRI Reagent by using a glass-teflon homogenizer. The homogenate was incubated at room temperature for $5 \mathrm{~min}$ to permit the complete dissociation of nucleoprotein complexes. 0.1-0.2 $\mathrm{ml}$ of BCP were added, shaked vigorously, and stored at room temperature for another $15 \mathrm{~min}$. After centrifugation of the sample at $12000 \mathrm{xg}$ for $15 \mathrm{~min}$ at $4^{\circ} \mathrm{C}$, the colorless upper aqueous phase was transferred into a new tube. The RNA was precipitated by adding $0.5 \mathrm{ml}$ of isopropanol. Finally, the pellet was washed with $75 \%$ ethanol, and dissolved in 80-100 $\mu$ l of DEPC- $\mathrm{H}_{2} \mathrm{O}$.

\subsubsection{Isolation of poly(A)-enriched RNA}

To isolate polyadenylated mRNA, the Qiagen Oligotex kit was used. The purification procedure makes use of oligo-dT coated latex particles that provide a hybridization carrier on which nucleic acids containing polyadenylic acid sequences can efficiently immobilized and easily recovered. $400 \mu \mathrm{g}$ total RNA was mixed with $400 \mu \mathrm{l}$ of $2 \mathrm{x}$ binding buffer and $30 \mu \mathrm{l}$ of 
oligotex suspension and incubated for $3 \mathrm{~min}$ at $65^{\circ} \mathrm{C}$ to disrupt secondary RNA structures. A second incubation for $10 \mathrm{~min}$ at room temperature allowed hybridization between oligo (dT)30 linked latex particles and the poly (A) mRNA tails. Afterwards, the oligotex resin containing the RNA was pelleted by centrifugation for $2 \mathrm{~min}$ at full speed. After removing the supernatant, the pellet was resuspended in $400 \mu \mathrm{l}$ of wash buffer QW2 and transferred to a spin column. The column was washed 2 times with washing buffer QW2, and finally RNA was eluted with $100 \mu \mathrm{l}$ of $\mathrm{H}_{2} \mathrm{O}$.

\subsubsection{Isolation of plasmid DNA}

\subsection{Small-scale isolation of plasmid DNA}

$5 \mathrm{ml}$ of LB medium with the appropriate antibiotic was inoculated with a single $E$. coli colony and incubated overnight at $37^{\circ} \mathrm{C}$ with shaking. $1.5 \mathrm{ml}$ of this culture was centriguted at 5000 $\mathrm{xg}$ for $10 \mathrm{~min}$. The pellet was resuspended in $200 \mu \mathrm{l}$ of solution E1. After adding equal volumes of solutions E2 and E3, respectively, the pellet was incubated on ice for $15 \mathrm{~min}$, and centrifuged at full speed at $4^{\circ} \mathrm{C}$. The supernatant was transferred into a new tube and $1 \mathrm{ml}$ of $100 \%$ ethanol was added to precipitate the DNA. It was then stored at $-20^{\circ} \mathrm{C}$ for $30 \mathrm{~min}$, centrifuged at full speed for $30 \mathrm{~min}$ and finally the pellet was dissolved in $30 \mu \mathrm{l}$ of $\mathrm{H}_{2} \mathrm{O}$.

\subsection{Large-scale isolation of plasmid DNA}

$80 \mathrm{ml}$ of LB medium containing an appropriate antibiotic $(50 \mu \mathrm{g} / \mathrm{ml})$ was inoculated with a single E.coli colony and incubated overnight at $37^{\circ} \mathrm{C}$ with shaking. In order to pellet the cells, it was centrifuged at 6,000 $\mathrm{xg}$ for $15 \mathrm{~min}$. The pellet was resuspended in $4 \mathrm{ml}$ of solution E1. To lyse the cells $4 \mathrm{ml}$ of solution E2 was added, mixed gently, and incubated for 2-3 min at room temperature. Equal amount of solution E3 was added to the tube, and mixed immediately by inverting. The mixture was centrifuged at $20,000 \mathrm{xg}$ for $30 \mathrm{~min}$ at $20^{\circ} \mathrm{C}$. Meanwhile, the column that was provided by the kit was equilibrated with $10 \mathrm{ml}$ of solution E4. The clear lysate after the centrifugation was applied to the equilibrated column. The column was then washed twice with $10 \mathrm{ml}$ of solution E5. Finally, the DNA was eluted with 5 $\mathrm{ml}$ of solution E6. To precipitate the DNA, 0.7 Vol of isopropanol was added, and centrifuged at $14,000 \mathrm{xg}$ for $30 \mathrm{~min}$ at $4^{\circ} \mathrm{C}$. The DNA was usually dissolved in $100 \mu \mathrm{lof} \mathrm{H}_{2} \mathrm{O}$. 


\subsection{Isolation of DNA fragments from agarose gels}

For the isolation of DNA fragments of 400-5000 bp in length from agarose gels, the Jet Sorb kit from Genomed, Bad Oeyenhausen, was used. The principle of this method depends on the high binding capacity of DNA to silica particles in high salt concentrations and elution in low salt solutions. After separation of DNA fragments on an agarose gel, the DNA fragment to be isolated was excised with a razor blade and weighed. $10 \mu \mathrm{l}$ of JETSORB suspension and 300 $\mu \mathrm{l}$ of buffer A1 were added to each $100 \mathrm{mg}$ gel slice. The agarose slice was melted and dissolved in buffer $\mathrm{A} 1$ at $50^{\circ} \mathrm{C}$ for $15 \mathrm{~min}$. After centrifugation at full speed for $30 \mathrm{sec}$, the pellet was washed once with $300 \mu \mathrm{l}$ of buffer A1 and 2 times with $300 \mu \mathrm{l}$ of reconstituted buffer A2 and allowed to dry at room temperature. To elute the DNA, the pellet was resuspended in $20 \mu \mathrm{l}$ of $\mathrm{H}_{2} \mathrm{O}$ and incubated at $50^{\circ} \mathrm{C}$ for $5 \mathrm{~min}$. After the final centrifugation at $14,000 \mathrm{xg}$ for $30 \mathrm{sec}$, the supernatant containing the DNA was transferred into a new tube. The typical yield of DNA fragments $>400$ bp was approx. 70-80\% (<400 bp , approx. 50\%).

\subsection{Isolation of DNA fragments from acrylamide gels}

For the isolation of small DNA fragments (50-300 bp) the DNA was separated on a polyacrylamide gel. After staining the gel with ethidium bromide, the desired band was cut out and transferred into a $1.5 \mathrm{ml}$ centrifuge tube. $500 \mu \mathrm{l}$ TE buffer was added to the gel slice and incubated at $50^{\circ} \mathrm{C}$ overnight, with shaking. After centrifugation at $12000 \mathrm{xg}$ at room temperature for $15 \mathrm{~min}$, the supernatant containing the DNA was precipitated by adding 1/10 Vol $3 \mathrm{M} \mathrm{NaAc}$ and $2.5 \mathrm{Vol} 100 \%$ of ethanol, washed once with 3 Vol $70 \%$ Ethanol, air dried and dissolved in an appropiate volume of water. 


\subsection{Determination of nucleic acid concentration}

The concentration of nucleic acids was determined photometrically by measuring absorption of the samples at $260 \mathrm{~nm}$. DNA quality (i.e. contamination with salt and protein) was checked by the measurements at 230, 280, and $320 \mathrm{~nm}$. The concentration can be calculated according to the formula :

$\mathrm{C}=(\mathrm{E} 260-\mathrm{E} \mathrm{320}) \times \mathrm{f} \times \mathrm{c}$

$\mathrm{C}=$ concentration of sample $(\mu \mathrm{g} / \mu \mathrm{l})$

E $260=$ absorption at $260 \mathrm{~nm}$

E $320=$ absorption at $320 \mathrm{~nm}$

$\mathrm{f} \quad=$ dilution factor

c = concentration (standard) / absorption (standard)

$\mathrm{c}=0.05 \mu \mathrm{g} / \mu \mathrm{l} \quad$ for double stranded DNA

$\mathrm{c}=0.04 \mu \mathrm{g} / \mu \mathrm{l} \quad$ for RNA

$c=0.03 \mu \mathrm{g} / \mu \mathrm{l} \quad$ for single stranded DNA

\subsubsection{Enzymatic modifications of DNA}

\subsubsection{Restriction of DNA}

Restriction cutting was performed by incubating double-stranded DNA molecules with an appropriate amount of restriction enzyme in its respective buffer as recommended by the supplier at optimal reaction temperature. Typical digestions included 2 to $10 \mathrm{U}$ of enzyme per microgram of DNA. The reactions were usually incubated for 1-3 hrs to insure complete digestion.

\subsubsection{Dephosphorylation of plasmid-DNA}

To prevent the recircularization of vector plasmid without insertion of foreign DNA, alkaline phosphatase treatment was peformed. Alkaline phosphatase catalyses the hydrolysis of 3'phosphate residues from DNA. The followings were mixed, 


\section{1-5 $\mu \mathrm{g}$ vector DNA}

$5 \mu 110 \times$ reaction buffer

$1 \mu \mathrm{l}$ alkaline phosphatase (1 U)

in a total volume of $50 \mu 1$

and incubated at $37^{\circ} \mathrm{C}$ for $30 \mathrm{~min}$. Then the reaction was stopped by heating at $85^{\circ} \mathrm{C}$ for 15 $\min$.

\subsubsection{Ligation of DNA fragments}

The ligation of an insert into a vector was carried out in the following reaction mix:

30 ng vector DNA

50-100 ng insert DNA

$1 \mu 1$ ligation buffer $(10 \mathrm{x})$

$1 \mu \mathrm{T} 4$ DNA ligase $(5 \mathrm{U} / \mu \mathrm{l})$

in a total volume of $10 \mu 1$.

Blunt-end ligations were carried out at $16^{\circ} \mathrm{C}$ overnight whereas sticky-end ligations were carried out at room temperature for 2-4 hrs.

\subsubsection{Transformation of bacteria}

$50 \mu 1$ of transformation competent cells (DH5 $\alpha$ ) were mixed with $10 \mu 1$ ligation reaction and placed on ice for $30 \mathrm{~min}$. The transformation reaction was then incubated at $42^{\circ} \mathrm{C}$ for $90 \mathrm{sec}$ and placed on ice for 2 more min. In order to accelerate bacteria growth, 200 $\mu 1 \mathrm{LB}$ medium was added to the reaction which was incubated at $37^{\circ} \mathrm{C}$ for $60 \mathrm{~min}$. After incubation, an aliquot of $200 \mu \mathrm{l}$ of the reaction mix was spreaded on IPTG/X-Gal plates. The plates were incubated overnight at $37^{\circ} \mathrm{C}$. The selection for the presence of the lacZ gene was carried out by the usual blue-white screening method (Sambrook et al., 1989). 


\title{
2.7.2.5 TA-Cloning
}

Taq and other polymerases seem to have a terminal transferase activity which results in the non-templated addition of a single nucleotide to the 3'-ends of PCR products. In the presence of all $4 \mathrm{dNTPs}, \mathrm{dA}$ is preferentially added. This terminal transferase activity is the basis of the TA- cloning strategy. For the cloning of PCR products, pGEM-T Easy Vector system which has $5 ` \mathrm{~T}$ overhangs was used. The followings were mixed :

\author{
$50 \mathrm{ng}$ of pGEM-T or pGEM-T Easy Vector \\ PCR product ( $1: 3$ vector : insert ratio) \\ $1 \mu 1$ T4 DNA Ligase 10x buffer \\ $1 \mu 1$ T4 DNA Ligase \\ in a total volume of $10 \mu \mathrm{l}$
}

The contents were mixed by pipetting and the reaction was incubated overnight at $4^{\circ} \mathrm{C}$.

\subsubsection{Filling-up reaction}

0.1-4 $\mu \mathrm{g}$ of digested DNA was mixed with $0.05 \mathrm{mM}$ dNTPs and 1-5 $\mathrm{U}$ of Klenow fragment. The reaction was incubated at $37^{\circ} \mathrm{C}$ for $10 \mathrm{~min}$, then stopped by heating at $75^{\circ} \mathrm{C}$ for $10 \mathrm{~min}$.

\subsubsection{Gel electrophoresis}

Gel electrophoresis is the technique by which mixtures of charged macromolecules, especially nucleic acids and proteins, are rapidly resolved in an electrical field.

\subsubsection{Agarose gel electrophoresis of DNA}

Agarose gels are used to electrophorese nucleic acid molecules from as small as 150 bases to more than 50 kilobases, depending on the concentration of the agarose and the precise nature of the applied electrical field (constant or pulse). $1 \mathrm{~g}$ of agarose was dissolved in $100 \mathrm{ml} 0.5 \mathrm{x}$ TBE buffer, and boiled in the microwave, then cooled down to about $50^{\circ} \mathrm{C}$ before adding $3 \mu 1$ ethidium bromide $(10 \mathrm{mg} / \mathrm{ml})$. The gel was poured into a horizontal gel chamber. 


\subsubsection{Agarose gel electrophoresis of RNA}

Single-stranded RNA molecules often have small regions that can form base-paired secondary structures. To prevent this, the RNA should be run on a denaturing agarose gel which contains formaldehyde, and additionally is pre-treated with formaldehyde and formamide. $1.25 \mathrm{~g}$ of agarose was dissolved in $100 \mathrm{ml}$ of $1 \mathrm{x}$ E-Buffer. After cooling it to about $50^{\circ} \mathrm{C}, 25 \mathrm{ml}$ of formaldehyde (37\%) was added, stirred and poured into a vertical gel chamber. To 10-20 $\mu \mathrm{g}$ of RNA, the following was added:

\section{$2 \mu 110 \times$ E-Buffer}

$3 \mu 1$ Formaldehyde

$8 \mu$ l Formamide (40\%)

$1.5 \mu 1$ Ethidium bromide

The samples were denatured at $65^{\circ} \mathrm{C}$ for $10 \mathrm{~min}$, chilled on ice and loaded to the gel. The gel was run at $80 \mathrm{~V}$ at $4^{\circ} \mathrm{C}$ for about 3-4 hrs.

\subsubsection{DNA / RNA length standards}

In order to be able to determine the size of the DNA fragments with gel electrophoresis, parallel to the DNA samples, the " 1 KB DNA Ladder " length standard (Gibco BRL, Karlsruhe) was loaded on the electrophoresis gel. For RNA electrophoresis an appropriate RNA size standard (RNA ladder, Gibco BRL) was used. 


\subsubsection{Blotting techniques}

\subsubsection{Dot blotting of DNA to nitrocellulose filters}

After assembling the dot-blot apparatus according to the manufacturer's instructions, the vacuum pump was switched on, and each well was washed with $20 \mathrm{x}$ SSC. Meanwhile, $10 \mu \mathrm{g}$ of genomic DNA was denatured at $95^{\circ} \mathrm{C}$ for $10 \mathrm{~min}$ and placed immediately on ice. To each sample, $150 \mu 1$ of ice-cold $20 \mathrm{x}$ SSC was added. Then the samples were applied to a separate well of the dot-blot apparatus. When all the wells were emptied, they were washed with $20 \mathrm{x}$ SSC again. Then the apparatus was dismantled, and the filter was baked for $2 \mathrm{hrs}$ at $80^{\circ} \mathrm{C}$.

\subsubsection{Southern blotting of DNA to nitrocellulose filters}

(Southern, 1975)

In Southern blotting, the transfer of denatured DNA from agarose gels to nitrocellulose membrane is achieved by capillary flow. $20 \mathrm{x}$ SSC buffer, in which nucleic acids are highly soluble, is drawn up through the gel into the nitrocellulose membrane, taking with it the single-stranded DNA which becomes immobilized in the membrane matrix. After electrophoresis of DNA, the gel was shaken in $0.25 \mathrm{M} \mathrm{HCl}$ for depurination. It was followed by shaking it further in denaturing solution for $30 \mathrm{~min}$, and $45 \mathrm{~min}$ in neutralizing solution. The transfer of the DNA to the nitrocellulose membrane took place through a Turbo-Blotapparatus (Schleicher \& Schuell, Dassel). About 26 Whatman filter papers with thickness of GB-003 were layed on a Stack Tray followed by 4 Whatman filter papers GB-002 and 1 Whatman filter paper GB-002 wetted with 20 x SSC. The equilibrated nitrocellulose filter which was wetted with $20 \mathrm{x}$ SSC was added to the top. The agarose gel was placed on the filter, and was covered with 3 Whatman filter papers GB-002 wetted with $20 \mathrm{x}$ SSC. The buffer tray was placed and filled with $20 \mathrm{x}$ SSC. Finally the buffer wick which was wetted with $20 \mathrm{x}$ SSC, and the wick cover were put on the top of the blot. The transfer was carried out overnight. Finally, after disassembling of the blot, the filter was washed shortly in $2 \mathrm{x}$ SSC and the DNA was fixed onto the filter by either baking it at $80^{\circ} \mathrm{C}$ for $2 \mathrm{hrs}$ or by UVcrosslinking (UV Stratalinker 1800, Stratagene, USA). 


\subsubsection{Northern blotting of RNA to nitrocellulose filters}

For the transfer of RNA to a nitrocellulose filter, the same procedure as above (2.6.2) was performed. In this case, however, the gel does not need to be denatured, but is transferred directly to the filter. RNA standard size was cut off from the filter and fixed for 15 min with $5 \%$ acetic acid on the membrane and stained for $10 \mathrm{~min}$ in staining solution (methylene blue $0.04 \%, 0.5 \mathrm{M} \mathrm{NaAc}, \mathrm{pH} 5.2$ ). The standard size was decolorized under running water and air dried.

\subsubsection{Labelling of nucleic acids}

\subsubsection{1 ,Random Prime“ method for generation of ${ }^{32} \mathrm{P}$ labelled DNA}

(Feinberg and Vogelstein, 1983)

The Rediprime ${ }^{\mathrm{TM}}$ II kit (Amersham, Braunschweig) was used for labelling DNA fragments radioactively. The labelling relies on the random priming principle developed by Feinberg and Vogelstein (1983). The labelling reaction mix contained dATP, dGTP, dTTP, exonuclease free Klenow enzyme and random primers in a dried, stabilised form. For probe labelling 2.5-25 ng of template DNA was denatured in a total volume of $46 \mu 1$ at $95^{\circ} \mathrm{C}$ for 5 min and snap cooled by placing on ice for $5 \mathrm{~min}$. It was then transferred to the Rediprime reaction cup and finally $4 \mu \mathrm{l}$ of $\left[\alpha-{ }^{32} \mathrm{P}\right] \mathrm{dCTP}(3000 \mathrm{uCi} / \mathrm{mmol})$ was added to the reaction mixture and mixed by pipetting up and down about 12 times. The labelling reaction was carried out at $37^{\circ} \mathrm{C}$ for $1-1.5 \mathrm{hrs}$. To cleaning the probe from free unincorporated nucleotides, the total reaction mixture of $50 \mu \mathrm{l}$ was given to a MicroSin ${ }^{\mathrm{TM}}$ column (Amersham, Braunschweig) and centrifuged at $735 \mathrm{xg}$ for $1 \mathrm{~min}$. The activity of the probe was measured by the scintillation counter (Tri-Carb 4530, Packard Instruments, Warrenville, USA).

\subsubsection{Hybridization of nucleic acids}

The membrane to be hybridized was first equilibrated in 2 x SSC and then transferred to a hybridization bottle. After adding $10 \mathrm{ml}$ of hybridization solution I it was incubated for $2 \mathrm{hrs}$ in the hybridization oven at an appropriate temperature which was usually $65^{\circ} \mathrm{C}$. Then the labelled probe and $300 \mu \mathrm{l}$ of salmon DNA were denatured at $95^{\circ} \mathrm{C}$ for $10 \mathrm{~min}$ and added to 
the hybridization solution. The hybridization was usually carried out for $18 \mathrm{hrs}$. After hybridization, the filter was washed for 10 min with $2 \mathrm{x}$ SSC at room temperature, with $2 \mathrm{x}$ SSC and with $0.2 \times$ SSC at the hybridization temperature, and if further washing was needed with $0.2 \times$ SSC containing $0.1 \%$ SDS at hybridization temperature. After drying the filter, it was sealed in Saran wrap, and exposed to X-ray films overnight at $-80^{\circ} \mathrm{C}$.

\subsubsection{Hybridization of RZPD filters}

Filters of the RZPD (Resources Center and Source Data Bank of the German Human Genome Project, Max Planck Institute of Molecular Genetics, Berlin) were hybridized in a large dish. After adding $500 \mathrm{ml}$ of hybridization solution II, they were incubated for $2 \mathrm{hrs}$ in the hybridization oven at $65^{\circ} \mathrm{C}$. The labelled probe and $300 \mu \mathrm{l}$ of salmon DNA were denatured at $95^{\circ} \mathrm{C}$ for $10 \mathrm{~min}$ and added to the hybridization solution. The hybridization was carried out for $18 \mathrm{~h}$. The filters were washed 4 times with the washing solution III at the hybridization temperature. After drying the filters, they were sealed in Saran wrap, and exposed overnight to X-Ray filmes at -80 within an autoradiography cassette. Potential positive clones were calculated and ordered at the RZPD for further analysis.

\subsubsection{Chromosomal localization}

DNA of the mouse Pfcp-specific cosmid clones, which were obtained from the Resource Center of the German Human Genome Project (RZPD), were labeled with digoxigenin-11dUTP by nick translation and hybridized in situ to metaphases of the WMP-1 cell line (Zörnig et al., 1995) from newborn mice carrying Robertsonian translocation chromosomes (Said et al., 1986). Signal detection via fluoresceinated avidin (FlTC-avidin) was performed as described (Lichter et al., 1988). Chromosomes were counterstained with 4,6-diamine-2phenylindole dihydrochloride (DAPl). Images of emitted light were captured separately by using the DAPI and FITC filter set and were subsequently merged and aligned. 


\title{
2.7.6 Non-Radioactive dye terminator cycle sequencing
}

Non-radioactive sequencing was performed using the Dye Terminator Cycle Sequencing-Kit (ABI, Weiterstadt). The reaction products were analyzed with automatic sequencing equipment, namely 373 A DNA Sequencer (ABI, Weiterstadt). For the sequencing reaction, four different dye labelled dideoxy nucleotides were used, which, when exposed to an argon laser, emitted fluorescent light which could be detected and interpreted. The reaction was carried out in a total volume of $10 \mu \mathrm{l}$ containing $1 \mu \mathrm{g}$ plasmid DNA or 100-200 ng purified PCR product, 10 pmol primer and $4 \mu \mathrm{l}$ reaction mix (contains dNTPs, dideoxy dye terminators and Taq DNA polymerase). Elongation and chain termination take place during the following program in a thermocycler: 5 min denaturing followed by 25 cycles at $95^{\circ} \mathrm{C}$ ( 30 $\mathrm{sec}), 55^{\circ} \mathrm{C}$ ( $15 \mathrm{sec}$ ) and $70^{\circ} \mathrm{C}$ ( $4 \mathrm{~min}$ ). After thermal cycling, the reaction product was precipitated with $1 / 10 \mathrm{Vol} 3 \mathrm{M} \mathrm{NaAc}$ and $2.5 \mathrm{Vol} 100 \%$ ethanol. The pellet was dissolved in $4 \mu 1$ of loading buffer, denatured at $95^{\circ} \mathrm{C}$ for $3 \mathrm{~min}$, and loaded to the sequence gel.

\subsubsection{Methods of the " polymerase chain reaction " (PCR)}

\subsubsection{PCR of plasmid-DNA}

PCR technique (Saiki et al.,1985) is employed to amplify DNA or RNA which are present in a very small quantity. The amplification is achieved by the use of synthetic oligonucleotides (primers) which flank the sequence to be amplified. These primers, under appropriate conditions, anneal to the denaturated target sequence and, in the presence of DNA polymerase and excess dNTPs, elongate, thus completing the complementary strand of the target sequence. The following reaction was placed in a $200 \mu 1$ reaction tube in a total volume of 50 $\mu 1$.

\author{
$5 \mu 1$ 10X PCR buffer \\ $3 \mu 150 \mathrm{mM} \mathrm{MgCl}_{2}$ \\ $1 \mu 110 \mathrm{mM}$ dNTPs \\ $1 \mu \mathrm{l}$ upstream primer(10pmol) \\ $1 \mu 1$ downstream primer (10pmol) \\ 100-500 ng DNA \\ $0.5 \mu 1$ Taq DNA polymerase
}




$$
\mathrm{x}_{2} \mathrm{O}
$$

standard programm:

$$
\begin{aligned}
& \text { segment } 1(1 \mathrm{x}) \quad 5 \min 94^{\circ} \mathrm{C} \text { (denaturation) } \\
& \text { segment } 2(35 \mathrm{x}) 1 \mathrm{~min} 94^{\circ} \mathrm{C} \text { (denaturation) } \\
& 1 \mathrm{~min} 55-60^{\circ} \mathrm{C} \text { (annealing) } \\
& 1 \min 72^{\circ} \mathrm{C} \text { (extension) } \\
& \text { segment } 35 \mathrm{~min} 72^{\circ} \mathrm{C} \text { (final extension) } \\
& \text { segment } 4 \quad 4^{\circ} \mathrm{C}
\end{aligned}
$$

\subsubsection{Reverse transcriptase PCR (RT-PCR)}

(Kogan et al., 1987)

RT-PCR is a very sensitive technique to determine the presence or absence of RNA templates or to quantify the level of gene expression. The amplification of RNA is also very useful for the determination of exon-intron boudaries. A cDNA strand, complementary to the RNA template is synthesized with the extension of a gene specific primer by the reverse transcriptase. After the cDNA synthesis is completed, the DNA is used as template for a PCR reaction as described in 7.7.1. In some cases $1 \mu \mathrm{l}$ of the first round amplification is added to a second PCR reaction containing a set of nested primers (primers which bind to sequences within the first round product). SUPERSCRIPT ${ }^{\mathrm{TM}}$ II RNase H Reverse Transcriptase ( Gibco/BRL, Karlsruhe ) was used to generate cDNA from RNA template as follows:

1-5 $\mu \mathrm{g}$ total RNA was mixed with $1 \mu \mathrm{l}$ of oligo (dT) 18 primer $(10 \mathrm{pmol} / \mu \mathrm{l})$ in a total volume of $11 \mu 1$. To avoid formation of RNA secondary structures which might interfere with the synthesis, the mixture was heated to $70^{\circ} \mathrm{C}$ for $10 \mathrm{~min}$, and then quickly chilled on ice. After a brief centrifugation, the followings were added to the mixture:

$$
\begin{aligned}
& 4 \mu 15 \text { x First Strand buffer } \\
& 2 \mu 10.1 \text { M DTT } \\
& 1 \mu 110 \mathrm{mM} \text { dNTPs } \\
& 1 \mu 1 \text { Rnasin }(10 \mathrm{U} / \mu \mathrm{l})
\end{aligned}
$$

The content of the tube was mixed gently and incubated at $42^{\circ} \mathrm{C}$ for $2 \mathrm{~min}$. Then, $1 \mu \mathrm{l}$ of reverse transcriptase enzyme (SUPERSCRIPT II RNase H - Reverse Transcriptase, GibcoBRL Life Technologies, USA) was added, and further incubated at the same temperature for $1 \mathrm{hr}$ for first strand cDNA synthesis. Afterwards the reaction was inactivated 
by heating to $70^{\circ} \mathrm{C}$ for $15 \mathrm{~min} .10 \%$ of the first strand product was used for subsequent PCR reactions.

\subsection{Cell biological methods}

\subsubsection{Transient transfection}

For in vitro promoter analysis, the cells were tranfected with 4 different DNA constructs containing deletions of the 5' flanking region of the human GCAP. The fragments were cloned into the vector pGL3 basic, a promoter-less vector, which contains luciferase as a reporter gene. Every construct was cotransfected with CMV-BGal vector, to have the expression of the $B$-galactosidase gene as a control for the transfection effiency. The vector pGL3 control was used as positive control. The culture was divided 24 hrs before the transfection, in order to provide normal cell metabolism to increase the likelihood of DNA uptake. The day before transfection, $1.4 \times 10^{5}$ cells were seeded per reaction, they were placed in 6-well plates and incubated at the same conditions as before. For the transfection, $2 \mu \mathrm{g}$ of DNA (construct) and $0.1 \mu \mathrm{g}$ CMV BGal were added to $100 \mu \mathrm{l}$ of pure medium (without antibiotic and serum). $10 \mu 1$ of SuperFect Transfection Reagent (Qiagen, Hilden) was added to the DNA solution, vortexed for $10 \mathrm{sec}$ and incubated at room temperature for 5-10 min. While the complex formation was taking place, the cells were washed with PBS and replaced with $600 \mu 1$ growth medium (containing antibiotics and serum). The liposomal embedded DNA was then transferred to the 6 well plates containing the cells and both were coincubated for 2-3 hours at $37^{\circ} \mathrm{C}$ and $5 \% \mathrm{CO}_{2}$. Thereafter, the medium containing the remaining complexes was removed, the cells were washed with PBS and fresh medium was added. Cells were harvested 48 hours later.

\subsubsection{Harvesting of the cells}

After the transfection, the cells were washed with PBS. The PBS was withdrawn and $1 \mathrm{mM}$ lysis buffer was added. The cells were then scraped and the cell extract was transferred to a $1.5 \mathrm{ml}$ reaction tube. Since the lysis reaction takes place at room temperature, the tubes were placed on ice until all the reactions had been harvested. They were then incubated at room temperature for $5 \mathrm{~min}$. After the lysis reaction completed, the proteins were separated from 
the rest of the cells by 5 min centrifugation at $4{ }^{\circ} \mathrm{C}$. The cell extract was stored at $-80^{\circ} \mathrm{C}$ until the luciferase and $\beta G a l$ assays.

\subsubsection{Luciferase assay}

(Ausubel et al., 1992)

For the determination of luciferase activity, $368 \mu$ l of luciferase buffer was added to $50 \mu 1$ of cell extract in a measuring tube (Sarstedt, Nümbrecht). Into each luminometer measuring tube, $200 \mu \mathrm{l}$ of luciferin solution was injected automatically and after a zero effect measurment of $20 \mathrm{sec}$ the light emission was detected in an additional time interval of further $20 \mathrm{sec}$. The light emission was displayed as Relative Light Units (RLU).

\subsubsection{B-Gal assay}

(Jain and Magrath, 1991)

The " Galacto Light ${ }^{\mathrm{TM}}$ kit " from company Tropix (Bedford, USA) was used for determination of $\beta$-Gal activity from cell extracts after cotransfection with luciferase constructs and B-Gal control vector. Galacton ${ }^{\mathrm{TM}}$ was diluted 1:100 with reaction dilution buffer. In a luminometer measuring tube, $10 \mu \mathrm{l}$ of cell extract was added to $133 \mu \mathrm{l}$ of reaction buffer in a distance of $30 \mathrm{sec}$. This distance corresponded to the time interval, in which the contents were measured later by luminometer. The contents were then incubated $60 \mathrm{~min}$ at room temperature and measured afterwards by the luminometer. Automatically $200 \mu \mathrm{l}$ of " light emission accelerator " solution was injected and determined after a zero measurement of $20 \mathrm{sec}$.

\subsubsection{CAT-ELISA}

(Porsch et al., 1993)

The CAT-ELISA was performed using the CAT-ELISA system (Boehringer, Mannheim, Germany) according to the manufacturer`s instruction. H12.1 and 1411HP cells were separately lipofected with $2.5 \mu \mathrm{g}$ of GCAP-CAT, pCAT3-control and pCAT3-basic (Promega, Madison, WI) plasmids and cultivated for $48 \mathrm{~h}$. After the transfection step, cells (2 $\mathrm{x} 10^{6}$ ) were washed two times in PBS and incubated in $1 \mathrm{ml}$ lysis buffer (Boehringer, 
Mannheim, Germany) for $10 \mathrm{~min}$ at room temperature. Cell extracts were centrifuged for 10 min at $4{ }^{\circ} \mathrm{C}$, the supernatant was removed and cell extracts were subsequently subjected to protein determination according to Lowry et al., (1951). Thereafter, a colorimetric enzyme immunoassay for quantitative determination of CAT enzyme activity was performed, and 200 $\mu 1$ at 1:2, 1:4 and 1:8 dilutions was pipetted into the wells of the microtiter plate (MTP) (Boehringer, Mannheim) and incubated for $1 \mathrm{hr}$ at $37^{\circ} \mathrm{C}$. The solutions were removed and wells were washed 5 times with $250 \mu \mathrm{l}$ of washing buffer for $30 \mathrm{sec}$ and $200 \mu \mathrm{l}$ of anti-CATdigoxigenin (anti-CAT-DIG) antibody working solution was added to each well and incubated for $1 \mathrm{~h}$ at $37^{\circ} \mathrm{C}$. Again, washing was performed as described above, and subsequently $200 \mu \mathrm{l}$ of anti-DIG-peroxidase (anti-DIG-POD) working solution was added into each well and incubated for $1 \mathrm{~h}$ at $37^{\circ} \mathrm{C}$. Again, washing was performed, and subsequently $200 \mu \mathrm{l}$ of peroxidase (POD) was added into each well and incubated for $30 \mathrm{~min}$ at room temperature. CAT enzyme activity was determined by measuring the absorbance of each well at $405 \mathrm{~nm}$ in a UV-spectrometer (Eppendorf, Hamburg). Data were normalized with respect to CAT enzyme activity of pCAT3-control transfected cells, which were used as a positive control, and with respect to total protein concentration of the cell extract. Each lipofection was performed in duplicate and repeated in two different experiments.

\subsubsection{Cellular localization of fusion proteins}

A fusion-construct was established by cloning the entire coding region of Pfcp in frame into the pEGFP-N1 expression vector (Clontech, Heidelberg) downstream of the EGFP-coding sequence. pEGFP-N1 encodes an enhanced green fluorescent variant of the Aequorea victoria green fluorescent protein (GFP). Mouse NIH3T3 fibroblast cells $\left(2 \times 10^{5}\right)$ were plated in multiwell chamber slides (Greiner Nunc, Nürtingen) $24 \mathrm{hr}$ before transfection. The construct DNA ( $4 \mu \mathrm{g}$ per $6 \mathrm{~cm}$ culture dish) was then introduced into the cells using the SuperFect Transfection Reagent (Quiagen, Hilden) according to the manufacturer`s instruction. Twentyfour hrs later, the transiently transfected NIH3T3 cells were fixed on chamber slides with 100 $\%$ methanol for $10 \mathrm{~min}$ and subsequently washed with PBS. Afterwards, cell nuclei were stained with 4',6'-diamidino-2'phenylindole dihydorchloride (DAPl; Boehringer Mannheim) and observed under a fluorescence microscope (BX-60, Olympus). 


\subsubsection{Metaphase Arrest}

The mouse NIH3T3 fibroblastes cells was transiently transfected with the pEGFP-N1-Pfcp construct. After $24 \mathrm{hr}$ of incubation at $37^{\circ} \mathrm{C}, 100 \mu \mathrm{l}$ of colchezin was added and the cells were incubated for further $24 \mathrm{hr}$ at $37^{\circ} \mathrm{C}$. Working up was as described in 8.6.

\subsection{Procedure for making GCAP-LTA transgenic mice using zygote injection}

Zygotes were removed from the oviducts of a female mouse that has mated the night before. The zygotes must be released from the cumulus cells that surround them. The zygotes were placed under a microscope with two micromanipulator setups. The zygote was held in place with a blunt holding pipette and the tip of the injection needle was filled with a solution containing DNA $(\sim 5 \mu \mathrm{g} / \mathrm{ml})$. The DNA was then injected into one of the pronuclei, usually the larger male pronucleus. The zygotes were then either transferred the same day, or cultured overnight to form 2-cell embryos and then transferred into the oviducts of 0.5-day pseudopregnant females. Approximately 50 percent of the eggs surviva to the 2-cell stage and approximately 20 percent to term. Twenty to thirty embryos were therefore transferred to the uterus of each female. Of the animals born, 10 to 30 percent should be transgenic (hemizygous) and contain one site of DNA integration. Developing mice were analysed for the integration of the transgene. The genotyping took place by means of PCR using specific sequence primers or by means of genomic Southern bloting and Dot bloting. The transgenic mice were created in the Max-Planck Institute for Experimental Medicine, University of Göttingen.

\subsubsection{Preparation of the DNA for the microinjection}

For microinjection experiments, the DNA fragment was isolated by restriction cutting from the vector and was isolated through an agarose gel. The DNA was taken up to microinjection buffers and adjusted to a concentration of $1-2 \mathrm{ng} / \mu \mathrm{l}$. 


\section{RESULTS}

\subsection{GCAP-LTA transgenic mice}

To study the susceptibility of primordial germ cells (PGCs) to malignant transformation in an in vivo system, we developed a transgenic mouse model. In this model we used the oncogenic activity of simian virus 40 (SV40) large tumor antigen (LTA). Using the specific promoter activity of germ cell alkaline phosphatase (GCAP) in PGCs, we generated a fusion gene, containing $1.7 \mathrm{~kb}$ of the human GCAP promoter 5'flanking region and the coding sequence of SV40 TAg $(2.7 \mathrm{~kb})$. Human GCAP is developmentally expressed in primordial germ cells and also from the 2-cell to blastocyst stage of preimplantation development and reappears in trace amounts in the adult testis (Hahnel et al., 1990). Furthermore, GCAP is reexpressed in precancerous stages of testicular germ cell tumors (carcinoma in situ) and also in more differentiated tumors (Hofmann et al., 1993). However, first we analyzed the regulatory sequences in the 5'-flanking region of human GCAP promoter which are responsible for its expression in different testicular germ cell tumors (Wada et al., 1993) to determine the minimal promoter region sufficient for a high and tissue specific expression of GCAP.

\subsubsection{Analysis of the human GCAP promoter region ( in vitro )}

\subsubsection{Analysis of a $1.7 \mathrm{~kb}$ promoter fragment in seminoma (H12.1) and non-seminoma (1411HP) cell lines}

A GCAP-CAT construct was kindly provided by Prof. Millan, La Jolla Cancer Research Foundation, La Jolla, California, USA. A mixture of human seminoma and non-seminoma cells (H12.1) and non-seminoma cells (1411HP) were separately transfected with GCAPCAT, pCAT3-basic (negative control) and pCAT3-control (positive control) plasmids and cultivated for $48 \mathrm{~h}$. Subsequently, cells were washed two times in PBS and incubated in reporter lysis buffer for $10 \mathrm{~min}$. Following lysis of transfected cells, cell extracts were subjected to a colorimetric enzyme immunoassay for quantitative determination of CAT enzyme. The results obtained from the CAT-Elisa experiment show that a $1.7 \mathrm{~kb}$ GCAP promoter 5 'flanking region is sufficient to achieve a high expression of the reporter gene in H12.1 cells. In 1411HP cells only background expression was detected (Fig. 3). 
A

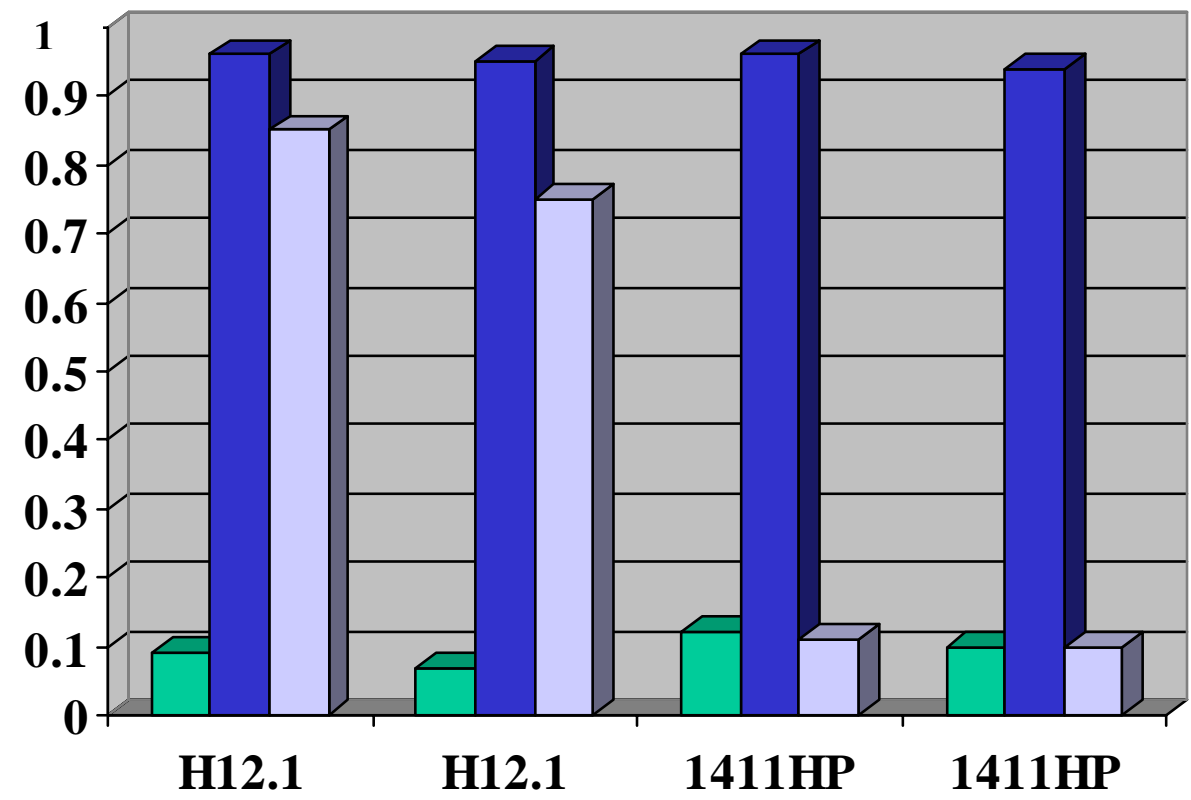

$\square$ CAT-Basic
$\square$ CAT-Control
$\square$ GCAP-CAT

B

\begin{tabular}{l|ll}
$\operatorname{GCAP}(1.7 \mathrm{~kb})$ & CAT & GCAP-CAT \\
\cline { 2 - 2 } & CAT & CAT-Control (Positive) \\
& CAT & CAT-Basic (Negative)
\end{tabular}

Fig. 3 (A). Expression of GCAP (1.7 kb)-CAT construct in a mixture of human seminoma and non-seminoma (H12.1) and in non-seminoma (1411HP) cells by using the CAT-Elisa-assay. H12.1 and 1411HP cells were transfected with GCAP (1.7 kb)-CAT, pCAT3-control and pCAT3-basic plasmids and CAT enzyme activity was determined by CAT-Elisa-assay. We observed that the expression of GCAP $(1.7 \mathrm{~kb})$-CAT construct is very high in human seminoma (H12.1) but not in non-seminoma (1411HP) cell lines. (B). Schematic representation of the constructs used in the CAT-Elisa-assay .

\subsubsection{Analysis of a $0.2 \mathrm{~kb}$ GCAP promoter fragment in different cell lines}

A $200 \mathrm{bp}$ fragment of the GCAP promotor was isolated by using a PCR with GCAP-specific primers on the GCAP-CAT construct. The generated 200 bp promoter fragment was subcloned into the XhoI and HindIII site of pGL3-basic vector (Promega) which contains luciferase as a reporter gene. The generated construct was termed GCAP (200 bp)-pGL3 (Fig. 4). 


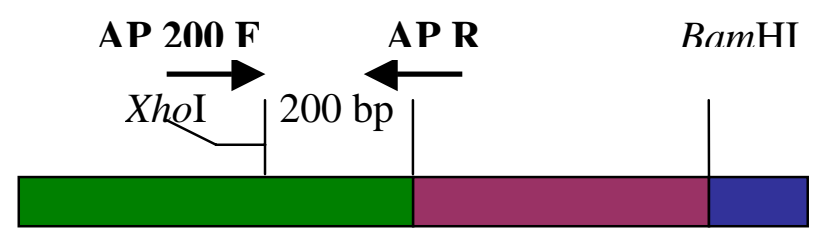

$1.7 \mathrm{~kb} \quad$ HindIII $1.6 \mathrm{~kb}$

\section{GCAP \\ CAT 3 UTR SV40}

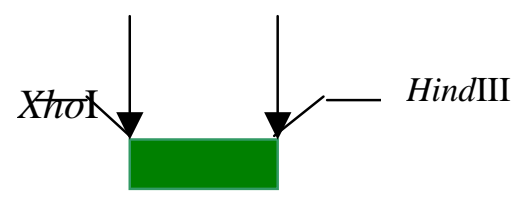

$200 \mathrm{bp}$

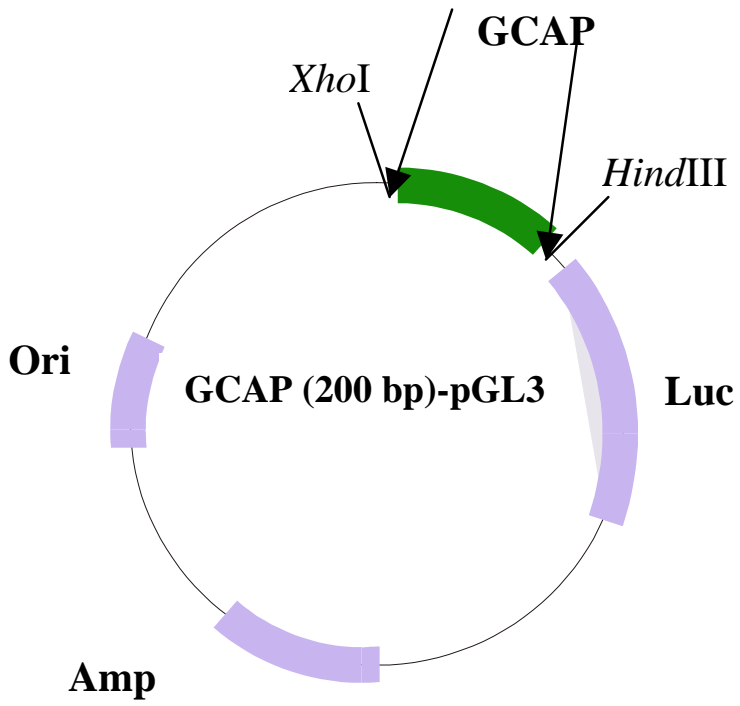

Fig. 4 Schematic diagram of GCAP (200 bp)-pGL3 construct. A 200 bp fragment of the human GCAP promoter was isolated by using a PCR with GCAP-specific primers on GCAP-CAT construct. The generated 200 bp promoter fragment was cloned into the luciferase pGL3-basic vector (Promega) with XhoI and HindIII. The generated construct was termed GCAP (200 bp)-pGL3.

Human embryonic carcinoma (Tera-1), mouse teratocarcinoma (F9) and embryonic mouse fibroblast (NIH3T3) cells were separately transfected with GCAP (200 bp)-pGL3, pGL3basic (negative control) and pGL3-control (positive control) plasmids. The pCMV-BGal plasmid was cotransfected to normalize transfection efficencies. By using luciferase assay, it could be demonstrated that the expression of a $200 \mathrm{bp}$ fragment of GCAP is sufficient to induce a high expression of luciferase in both F9 and Tera-1 cells (Fig. 5), while NIH3T3 cells which were used as a negative control showed no luciferase expression. 
A

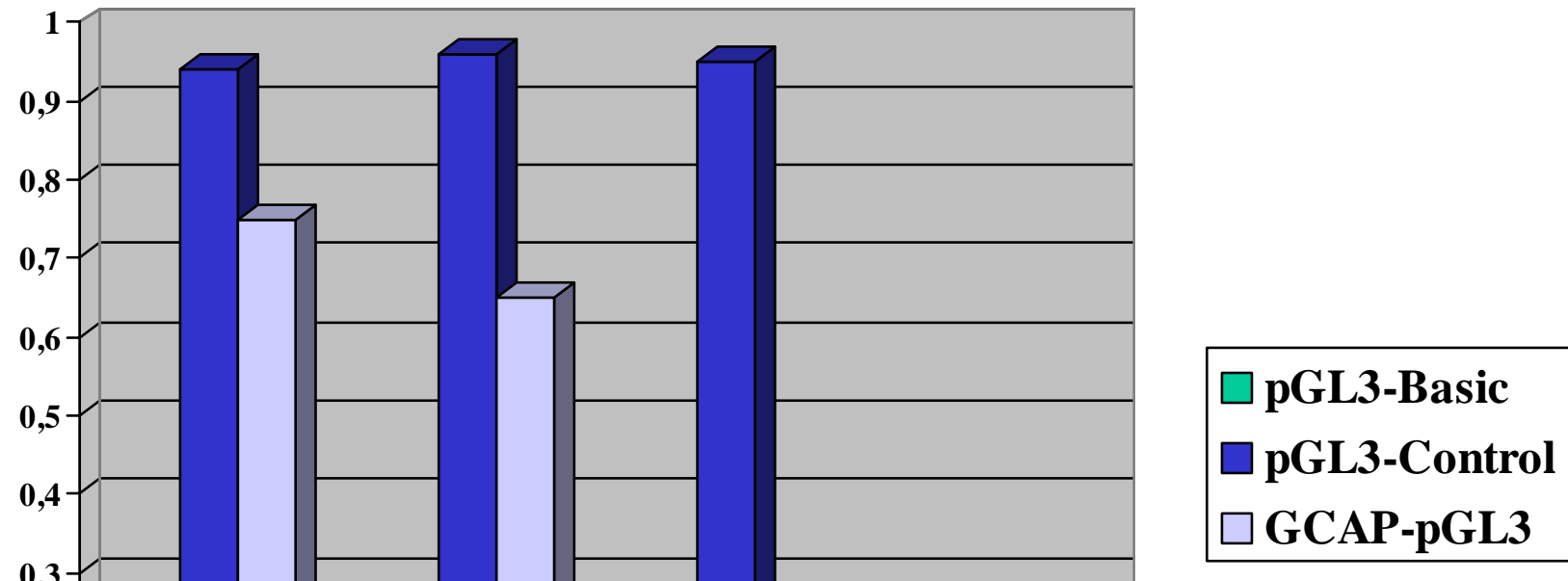

B

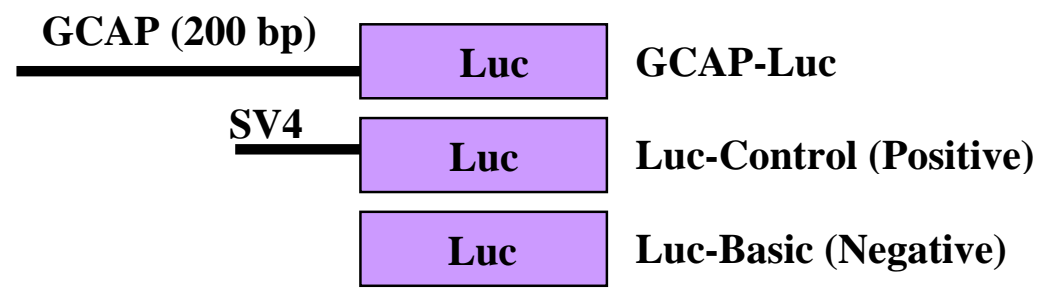

Fig. 5 (A). Expression of the GCAP (200 bp)-pGL3 gene in human embryonic carcinoma (Tera-1), mouse teratocarcinoma (F9) and embryonic mouse fibroblast (NIH3T3) cells. Tera-1, F9 and NIH3T3 cells were transfected with GCAP (200 bp)-pGL3, pGL3-control and pGL3-basic plasmids. By using a luciferase assay, high expression of the GCAP (200 bp)-pGL3 gene could be obtained in both F9 and Tera-1 cells, while no expression was observed in NIH3T3 cells which were used as a negative control. (B). Schematic representation of the constructs used in the luciferase assay. 


\subsubsection{Analysis of a 150-, 100- and 50 bp GCAP promoter fragment in a human embryonic carcinoma cell line (Tera-1)}

The three constructs:GCAP (150 bp)-pGL3, GCAP (100 bp)-pGL3 and GCAP (50 bp)-pGL3 were prepared as the previous construct GCAP (200 bp)-pGL3 by using the appropiate primers. The human embryonic carcinoma cell line (Tera-1) was transfected with GCAP-200, GCAP-150, GCAP-100, GCAP-50 bp-pGL3, pGL3-basic (negative control) and pGL3control (positive control) plasmids, respectively. The pCMV-BGal plasmid was cotransfected to normalize transfection efficencies. In all luciferase assays performed a high expression of all four constructs in Tera-1 cells was observed (Fig. 6).
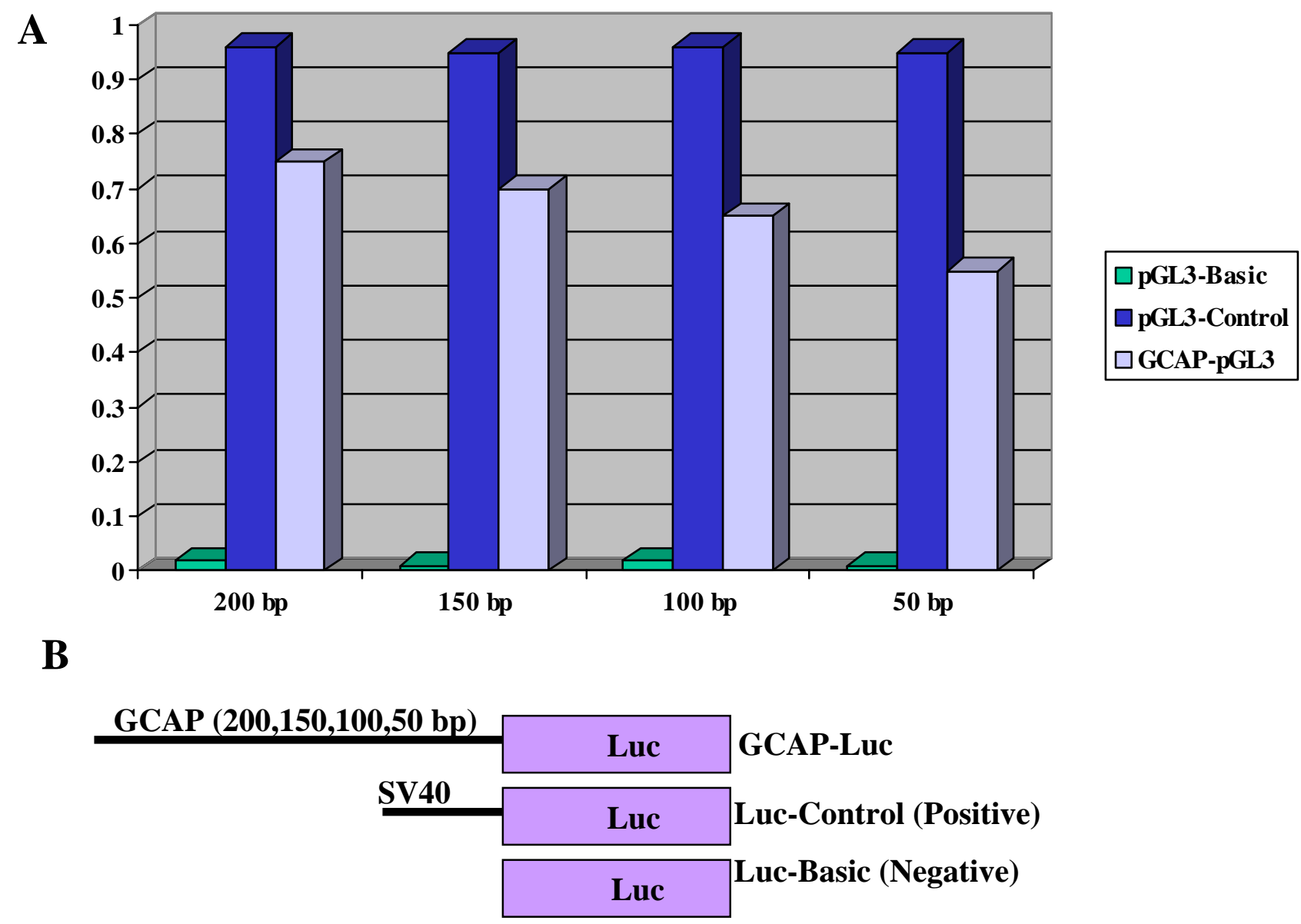

Fig. 6 (A). Expression of GCAP (200, 150, 100, 50 bp)-pGL3 constructs in human embryonic carcinoma (Tera-1) cells. Tera-1 cells were transfected with GCAP (200, 150, 100 and 50 bp)-pGL3 plasmids. By luciferase assay we could shown that the expression of GCAP (200, 150, 100 and 50 bp)-pGL3 constructs is very high in Tera-1 cells. (B). Schematic representation of the constructs used in the luciferase assay. 


\subsubsection{Generation of GCAP-LTA transgenic mice}

\subsubsection{GCAP-LTA construct}

The GCAP promoter was isolated with the restrictions enzymes NotI and HindIII from the tested GCAP-CAT construct (Wada et al., 1993). The isolated $1.7 \mathrm{~kb}$ promoter fragment was cloned into the pBK-CMV phagemid vector (Stratagene) with NotI and HindIII and the $2.7 \mathrm{~kb}$ SV40 large T antigen was cut with EcoRI and isolated from the LTB2T5 plasmid. The isolated LTA-fragment was then cloned into the EcoRI site of the GCAP-pBK-CMV construct. Thus, the subclone GCAP-LTA-pBK-CMV was generated (Fig. 7). From this clone, the construct GCAP-LTA was linearized with KpnI and SalI, the originated $4.4 \mathrm{~kb}$ fragment was isolated and prepared for microinjection into fertilized mouse oocytes. 


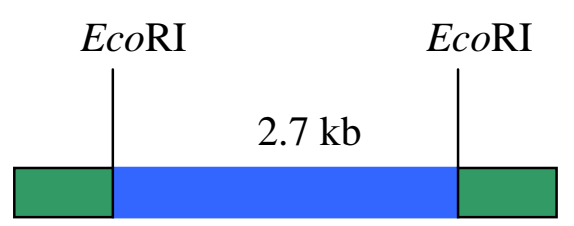

SV40 larg T antigen-LTB2T5
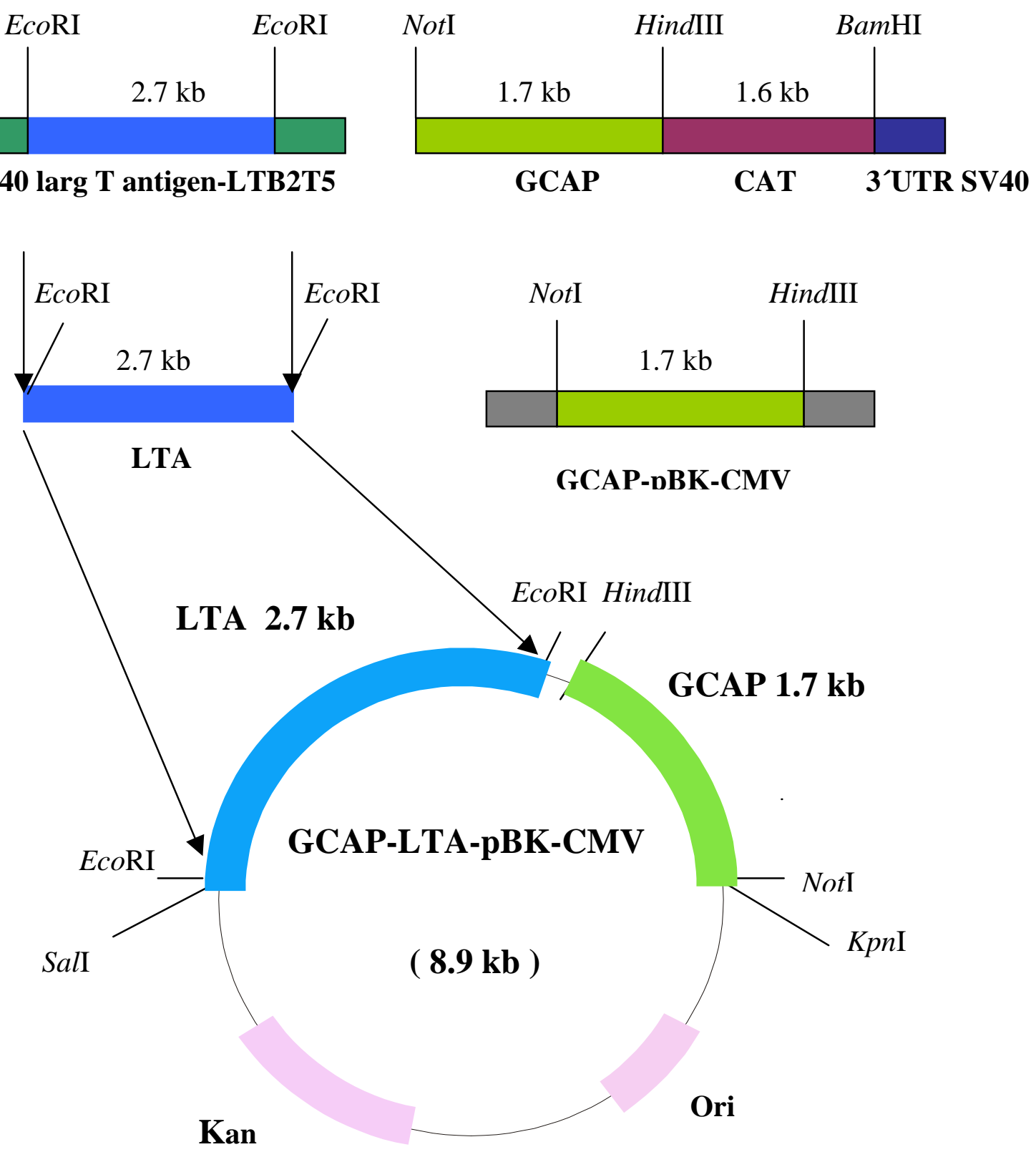

Fig. 7 Schematic representation of the strategy to generate the GCAP-LTA construct for microinjection. The $1.7 \mathrm{~kb}$ sequence of the $5^{\prime}$-flanking region of GCAP was isolated with NotI / HindIII from the GCAP-CAT construct and cloned into the pBK-CMV vector using the same restriction enzymes. The $2.7 \mathrm{~kb}$ LTA fragment was cut out from the LTB2T5 plasmid with EcoRI and cloned into the GCAP-pBK-CMV construct. 


\subsubsection{Generation of transgenic mice}

The previously described GCAP-LTA construct was injected into the larger male pronucleus of fertilized oocytes of FVB-mice. The microinjected oocytes were cultured overnight to form 2-cell embryos. About 140 two-cell stages, which survived after the microinjection, were retransferred into the oviducts of 0.5-day pseudopregnant females and finally about 29 mice were born. From this 29 mice, three lines were identified as founder transgenic mice (F0) that contain one site of DNA integration. The transgenic mice were examined at a postnatal age of 21 days by using Dot-Blot, Southern Blot and PCR experiments, respectively. After 56 days, the three founders were bred with wild type FVB mice. Their offsprings (F1) were bred together again, thus three homozygous lines (F2) (GL50, GL54, GL64) were generated.

\subsubsection{Genomic integration of the transgene}

\subsection{Analysis of transgenic founder mice (F0) generation}

For the identification of positive founder animals carrying the transgenic construct, genomic DNA was isolated from mouse tails and analyzed by Dot-blotting and subsequent hybridization using a radiolabeled $2.7 \mathrm{~kb}$ LTA fragment as a probe. The transgenity of the positive founder animals was also confirmed by Southern Blot experiments. Genomic DNA from F0 animals was digested with EcoRI overnight, separated on a $0.8 \%$ horizontal agarose gel, blotted and finally hybridized with a LTA probe. Out of 29 animals, three were identified as positive founder animals by Dot-blot analysis and the integration of the construct into the genome was verified by Southern blotting (Fig. 8). 


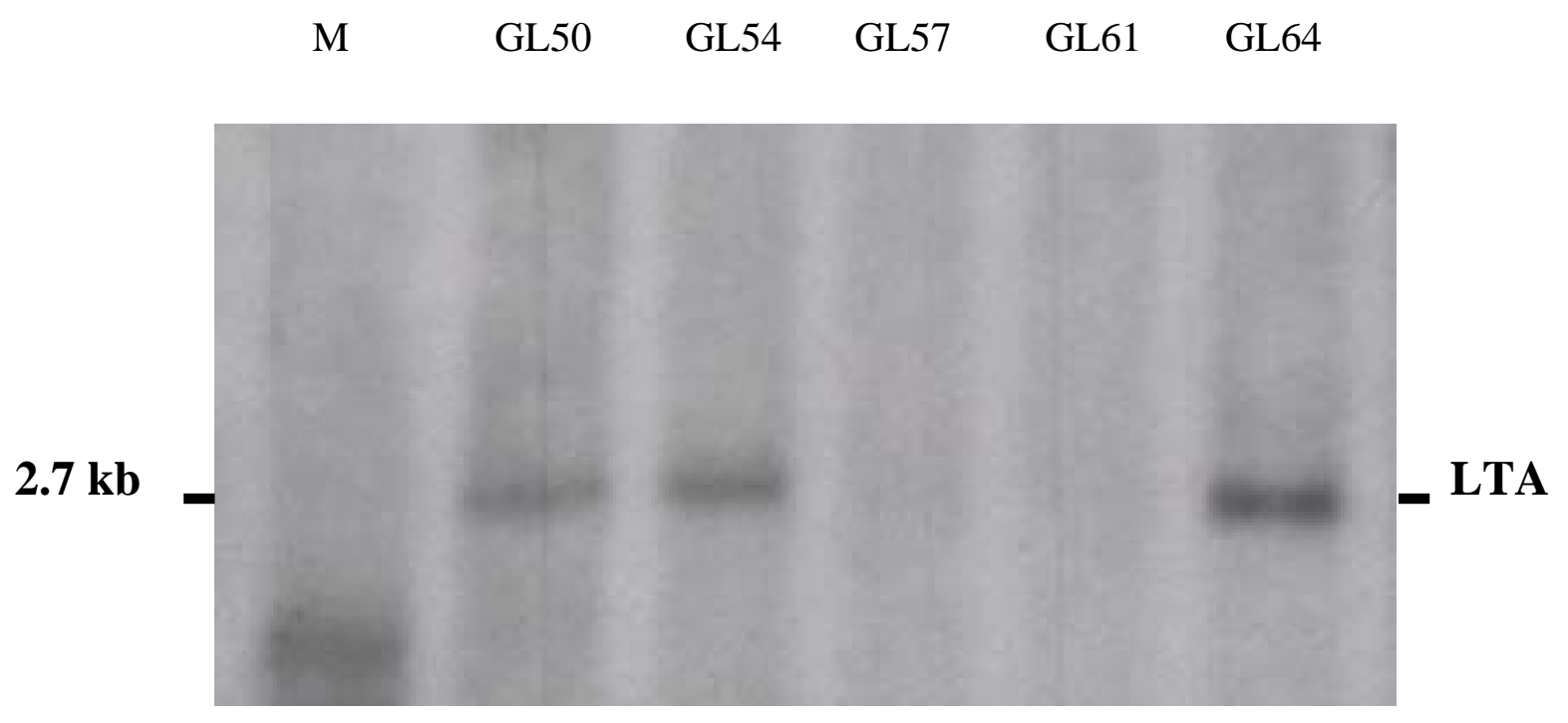

Fig. 8 Southern blot analysis of genomic DNA from five founder transgenic mice (GL50, GL54, GL57, GL61 and GL64). $15 \mu \mathrm{g}$ of genomic DNA from transgenic founder animals (F0) was digested with EcoRI, and hybridized with a LTA probe. The presence of a $2.7 \mathrm{~kb}$ hybridization signal (GL50, GL54 and GL64) confirmed the integration of the construct into the genome of these mice. M: DNA length standard.

\subsection{Analysis of the transgenic F1 generation}

To establish a transgenic line, the positive female founder mouse GL54 (F0) was bred with a male wild type FVB mouse to obtain heterozygous mice (F1). In total, 17 offsprings (12 females, 5 males) were obtained and analyzed by Dot-blotting and hybridization with a LTA probe (Fig. 9). 


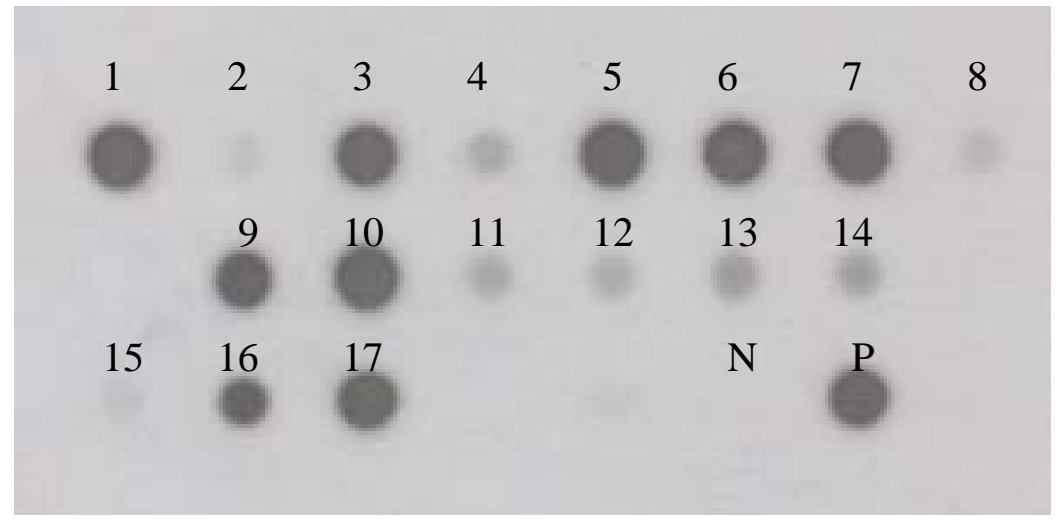

Fig. 9 Dot-blot analysis of genomic DNA from F1 generation animals of the GCAP-LTA transgenic line GL54. Offsprings of the F1 generation from breeding of the positive founder mouse with a wild type mouse were analyzed by Dot-blotting. $10 \mu \mathrm{g}$ of genomic DNA was transferred on a membrane by Dot-blotting, and hybridized with ${ }^{32} \mathrm{P}$ labeled LTA probe. Number $1,3,5,6,7,9,10,16,17$ were identified to be heterozygous. $\mathrm{N}$ represents the negative control (wild type mouse genomic DNA) and $\mathrm{P}$ represents the positive control (transgenic founder mouse genomic DNA).

\subsection{Analysis of the transgenic F2 generation}

To obtain homozygous mice, three heterozygous male mice (F1) were bred with three heterozygous female mice (F1). In total 30 offsprings (F2) were obtained comprising of 17 female and 13 male mice (Fig. 10 A). To identify homozygous F2-mice, all offsprings were bred with wild type FVB mice (Fig. 10 B). Transgeneity of the F2 and F3 generation was confirmed by Dot-blotting and following hybridization as described before. 
A

\section{F2 - generation}

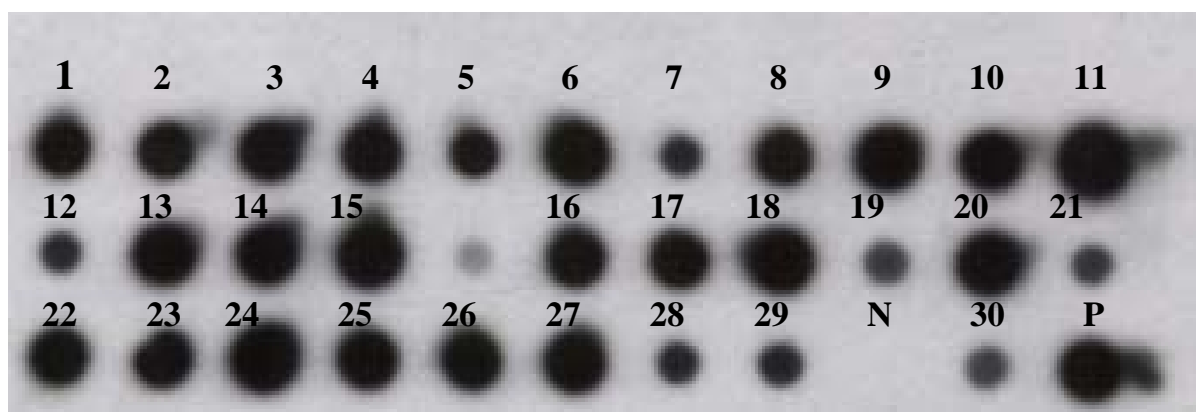

B Breeding of F2 mice with wild type FVB

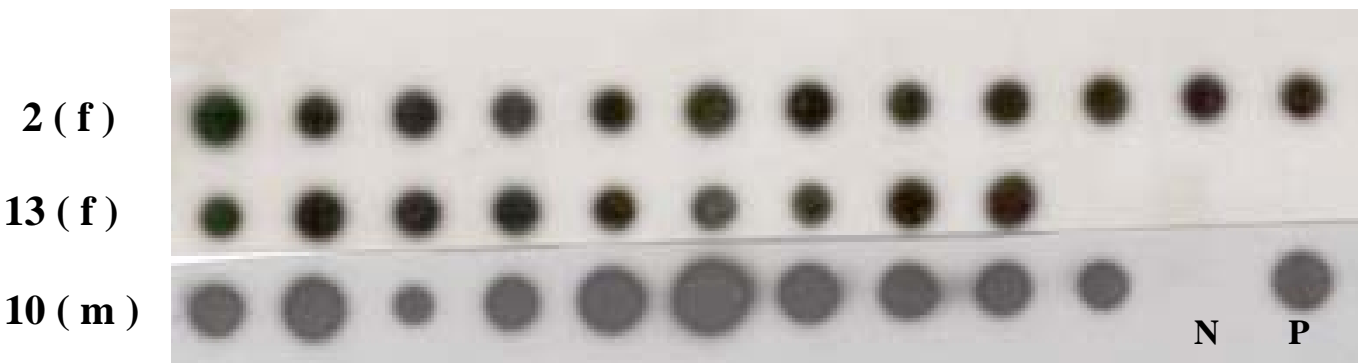

Fig. 10 (A) Dot-blot analysis of genomic DNA from animals of the F2 generation of GCAP-LTA transgenic line. In total, 30 offsprings of the F2 generation from breeding of three heterozygous male mice with three heterozygous female mice (F1) were analyzed by Dot-blotting. (B) The offsprings from breeding of one male from the F2 generation (number 10) and two females from the F2 generation (number 2 and 13) with FVB wild type mice were analyzed by Dot-blotting. All offsprings were found to be transgenic, indicating homozygosity of F2 animals number 2, 10 and 13. N represents the negative control (wild type mouse genomic DNA) and P represents the positive control (transgenic founder mouse genomic DNA).

\subsection{Analysis for homozygosity of the F3 generation}

In order to confirm homozygosity of the F2 generation, the male homozygous mouse F2 was bred with the two female homozygous mice from the F2 generation. All of their offsprings (F3) were found to be transgenic (Fig. 11), confirming the homozygous constitution of their parents. 


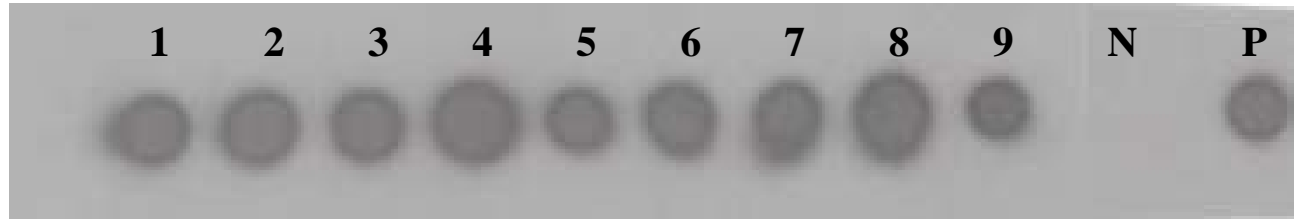

Fig. 11 Dot-blot analysis of genomic DNA from animals of the F3 generation of GCAP-LTA transgenic line. Nine offsprings of the F3 generation from breeding of one homozygous male mice with two homozygous female mice $(\mathrm{F} 2)$ were analyzed by Dot-blotting . N represents the negative control (wild type mouse genomic DNA) and $\mathrm{P}$ represents the positive control (transgenic founder mouse genomic DNA).

\subsubsection{Expression analysis of LTA in transgenic mice}

In the used LTA-sequence spanning $2.7 \mathrm{~kb}$, an intron (which is $345 \mathrm{bp}$ ) is located between the two exons. The first exon is about $271 \mathrm{bp}$ in length containing $25 \mathrm{bp}$ of the $5^{\prime}$-untranslated region (UTR) and 246 bp of the coding sequence including the start codon ATG. The second exon is about 2044 bp in length containing 1884 bp of the coding sequence and an additional 160 bp of the 3'-untranslated region (3'-UTR SV40) (Fig. 12).

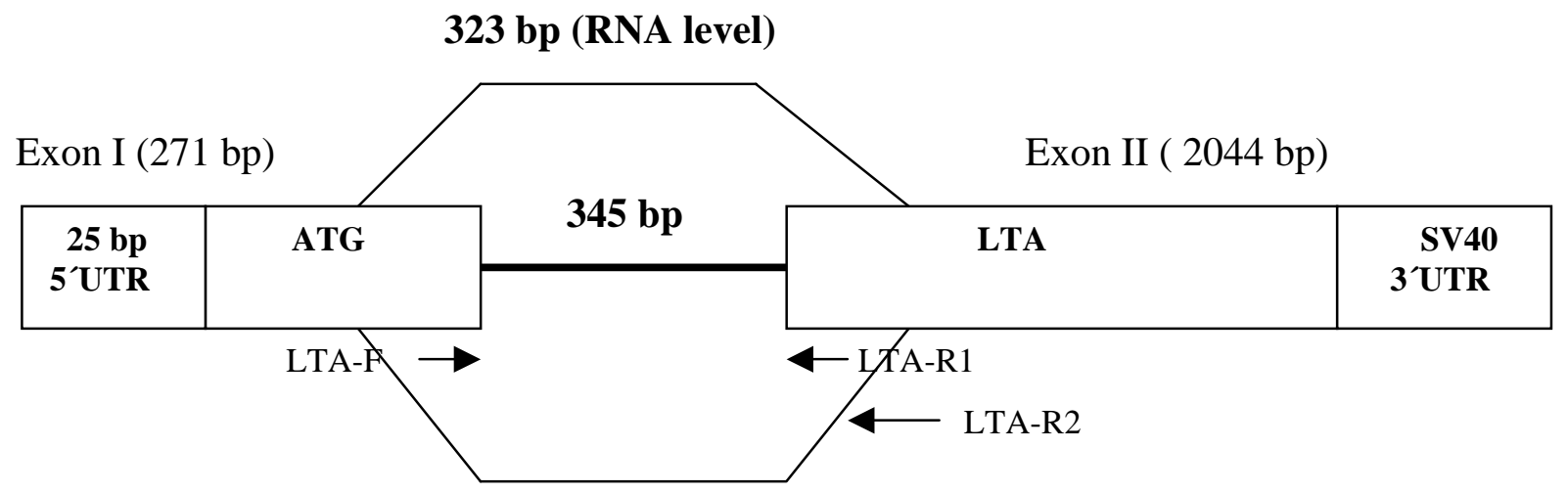

669 bp (genomic level)

Fig. 12 Schematic representation of the genomic structure of SV40 large T antigen. Exon 1 is 271 bp in length including $25 \mathrm{bp}$ of the $5^{\prime}$-UTR and $246 \mathrm{bp}$ of the coding sequence. Exon 2 contains $1884 \mathrm{bp}$ of the coding sequence and $160 \mathrm{bp}$ of the SV40 3'-UTR. There is an intron between the two exons which is $345 \mathrm{bp}$ in length. Primers used in RT-PCR amplifications are shown. At the RNA level a $323 \mathrm{bp}$ fragment was amplified with primers LTA-F and LTA-R2, at the genomic level a 669 bp fragment was amplified. 


\subsubsection{LTA expression in the adult testis of transgenic mice}

After a period of 20 months, no malignant transformation was observed in testes of transgenic mice. In order to determine LTA expression in testes of transgenic mice, total RNA was isolated from the testes of three heterozygous transgenic lines (GL50, GL54, GL64). In addition, Poly $(\mathrm{A})^{+}$RNA was isolated from total RNA of the same tissue. About $20 \mu \mathrm{g}$ of total RNA and $5 \mu \mathrm{g}$ of Poly $(\mathrm{A})^{+}$RNA were transferred on a membrane by Northern blotting and subsequently hybridized with a LTA probe. From this experiment, LTA transcript was observed in the three transgenic lines (Fig. 13 A). An immortalized germ cell line (GC-1spg), previously identified as an intermediate between type B spermatogonia and preleptotene spermatocytes was used as a positive control, testicular wild type-RNA was used as a negative control. The filter was rehybridized with a $\beta$-actin probe to show the integrity of the RNA samples (Fig. 13 B).
A
$\operatorname{Poly}(\mathrm{A})^{+}$RNA
M GL50 GL54 GL64
GC-1 N W
total RNA
GL50 GL54 GL64

$2.7 \mathbf{~ k b}$

- LTA

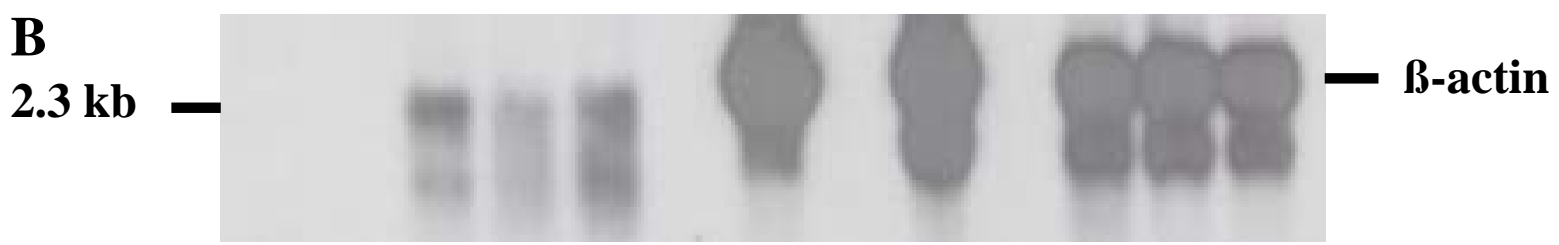

Fig. 13 (A) Northern blot analysis of heterozygous transgenic GCAP-LTA mice. $20 \mu \mathrm{g}$ of total RNA and 5 $\mu \mathrm{g}$ of Poly $(\mathrm{A})^{+}$RNA from the testis of transgenic lines GL50, GL54 and GL64 were used in Northern blot experiments and were hybridized with a LTA probe. There was no LTA transcript detectable on RNA derived from testicular tissues. The spermatogonia cell line (GC-1spg) was used as a positive control. (B) In order to verify the integrity of the RNA samples, the filter was rehybridized with a ß-actin probe. M: DNA length standard. $\mathrm{N}$ represents the negative control $\left(\mathrm{H}_{2} \mathrm{O}\right.$ instead of RNA) and W represents testis RNA from wild type mice. 
In order to further investigate the expression of LTA, RT-PCR analysis was carried out. Poly $(\mathrm{A})^{+}$RNA was obtained from total RNA which was isolated from the testes of both heterozygous and homozygous adult mice of the transgenic line GL54. RT-PCR was performed by using gene-specific primers for LTA (LTA-F and LTA-R2). The presence of a 323 bp LTA product in testis RNA showed expression of the transgene in line GL54 (Fig. 14 A). An immortalized mouse spermatogonia cell line (GC-1spg) known to express LTA was used as a positive control. In order to verify the integrity of the RNA, RT-PCR with genespecific primers for mouse GAPDH was performed (Fig. 14 B).

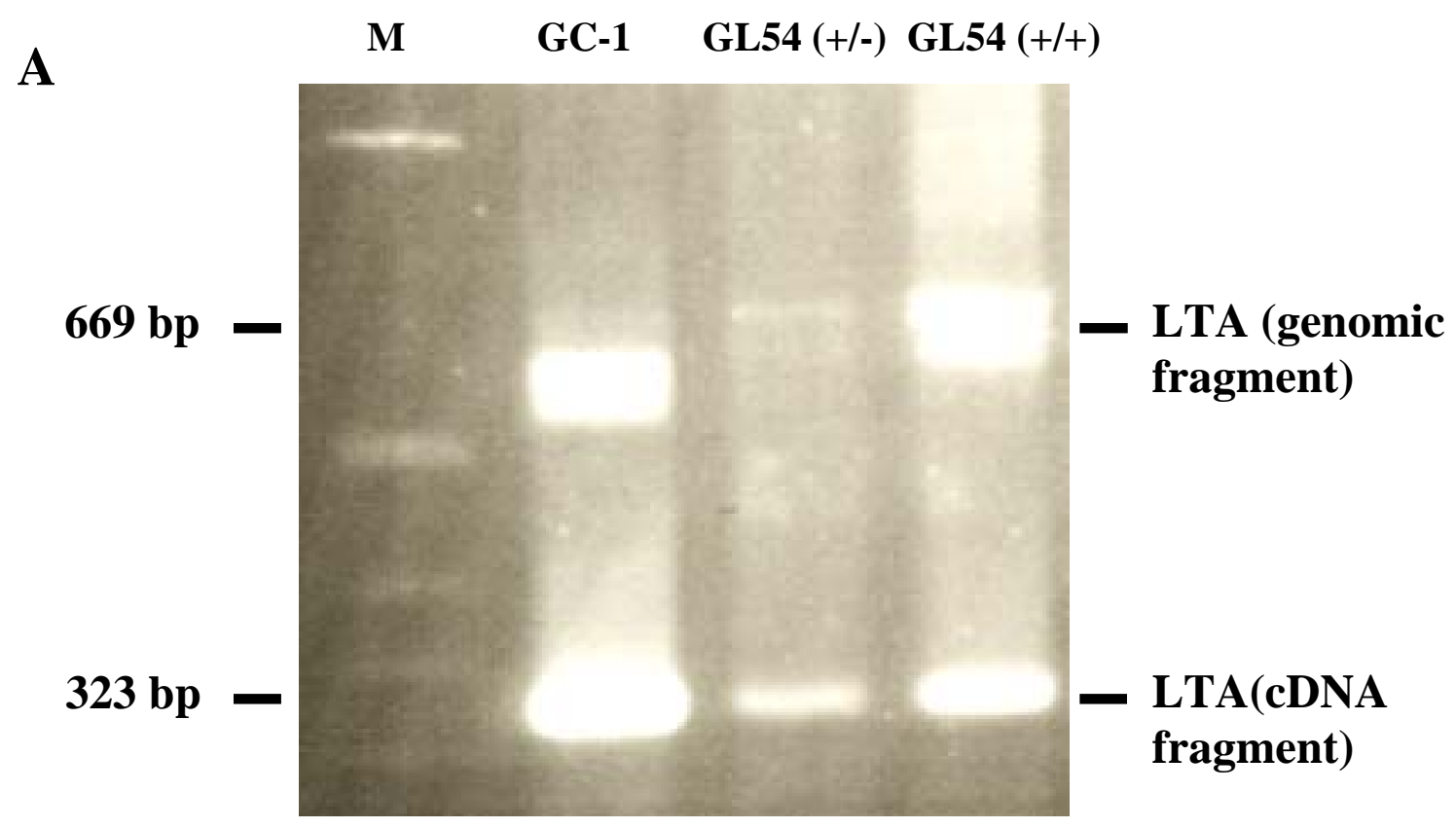

B

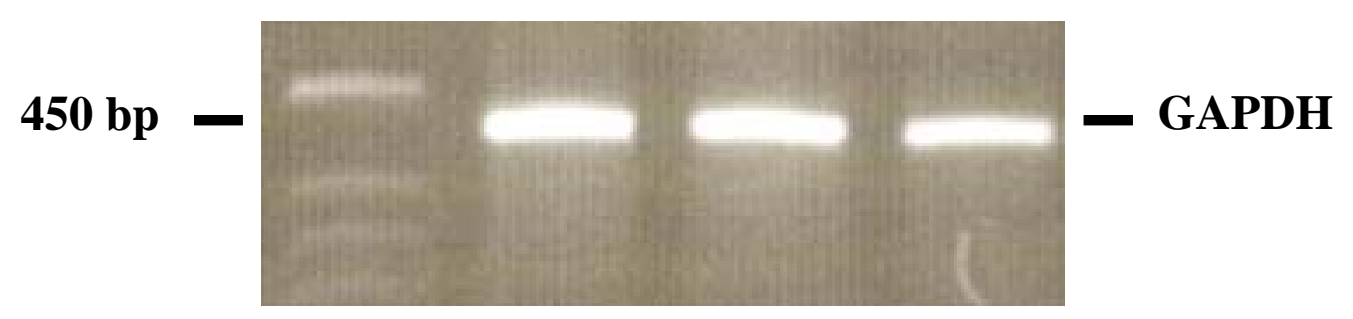

Fig. 14 (A) Expression analysis of LTA in testes of adult heterozygous and homozygous transgenic mice (line GL54) by using RT-PCR. Poly(A) ${ }^{+}$RNA was isolated from the testes of both heterozygous and homozygous transgenic animals. Approximately $1 \mu \mathrm{g}$ Poly $(\mathrm{A})^{+} \mathrm{RNA}$ from testis and 10 pmol primers LTA-F and LTA-R2 were used for RT-PCR. The size of the product was determined to be $323 \mathrm{bp}$ in both heterozygous and homozygous transgenic animals and subsequently confirmed by sequencing. The GC-1spg cell line was used as a positive control. (B) RT-PCR with gene specific primers for mouse GAPDH was performed to show integrity of Poly(A) $)^{+}$RNA samples. M: DNA length standard. 


\subsubsection{LTA-Expression analysis during embryonic development}

The sex of prenatal embryos was determined at different stages of development (8.5-, 10.5and $12.5 \mathrm{dpc}$ ) through PCR by using gene specific primers for mouse ZFY (Zwingman et al., 1993). Total RNA was isolated from whole embryos (males and females) at $8.5 \mathrm{dpc}$. For the developmental stages 10.5 and $12.5 \mathrm{dpc}$ Poly $(\mathrm{A})^{+} \mathrm{RNA}$ was isolated. For the postnatal stages 15.5 and 17.5 day Poly $(\mathrm{A})^{+}$RNA from testis tissues was prepared. $1 \mu \mathrm{g}$ RNA was used for RT-PCR. RNA from GC-1spg cells was used as a positive control. An expression of LTA was observed only in 8.5 dpc male embryos (Fig. 15 A). To show the integrity of the RNA and Poly(A) ${ }^{+}$RNA samples, RT-PCR with gene specific primers for mouse GAPDH was performed (Fig. 15 B).

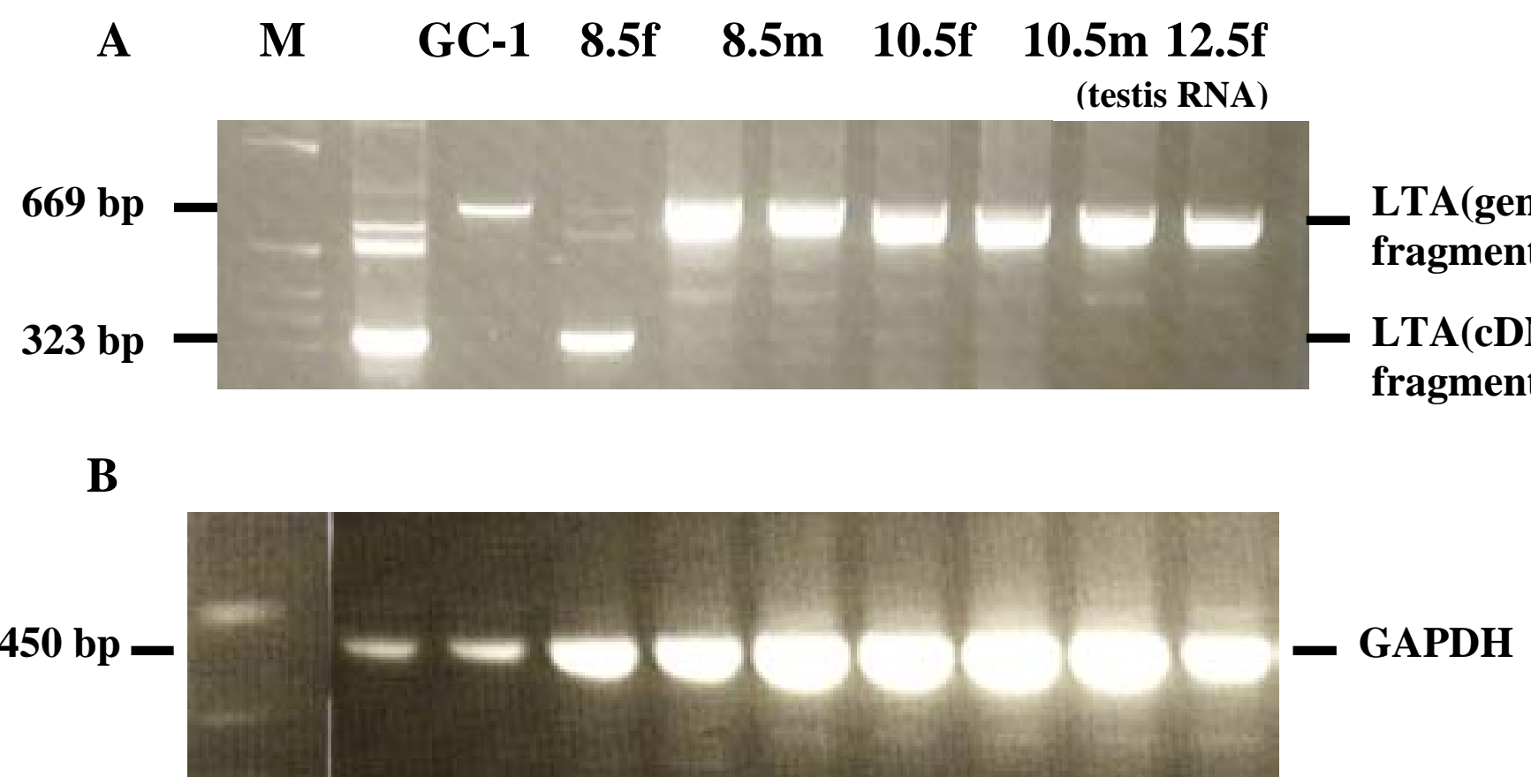

Fig. 15 (A) LTA expression during embryonic development by using RT-PCR. $1 \mu \mathrm{g}$ of total RNA from $8.5 \mathrm{dpc}$ embryos and $1 \mu \mathrm{g}$ of Poly(A) ${ }^{+} \mathrm{RNA}$ from 10.5 and $12.5 \mathrm{dpc}$ embryos as well as $1 \mu \mathrm{g}$ of $\operatorname{Poly}(\mathrm{A})^{+}$RNA of 15.5 and 17.5 day postnatal testis were used for RT-PCR with the primers (10 pmol) LTA-F and LTA-R2. We could detect LTA products of 323 bp only in RNA from 8.5 dpc embryos. RNA from GC-1spg cells was used as a positive control. (B) RT-PCR with gene specific primers for mouse GAPDH was performed in order to verify the integrity of RNA and Poly (A) ${ }^{+}$RNA samples. M: DNA length standard. 


\subsection{Isolation of a cDNA of a new family of PHD-finger-like chromatin proteins ( Pfcp )}

Using a suppression subtractive hybridization ( $\mathrm{SSH}$ ) which was performed on RNAs from the spermatogonia-derived cell line GC-1spg and the spermatocyte-derived cell line GC-4spc a $890 \mathrm{bp}$ cDNA fragment from the 3'UTR of a unknown mouse gene was initially isolated (Tascou et. al., 2000). By using Northern blot experiments it was demonstrated that only one transcript of this clone exists which is approximately $1.2 \mathrm{~kb}$ in size. From the deduced protein sequence a domain was detected known as " PHD-finger " like domain known to be involved in chromatin binding (Schindler et al., 1993). Thus we named the mouse cDNA sequence of this clone " Pfcp " (PHD-finger-like chromatin proteins). The Pfcp cDNA consists of a 5 UTR of $77 \mathrm{bp}$ and an ORF of $330 \mathrm{bp}$ encoding a protein of 110 amino acids. The 3 'UTR consists of $483 \mathrm{bp}$ and contains a putative polyadenylation signal (AATAAA) (Fig. 16).

A

\section{Pfcp cDNA}

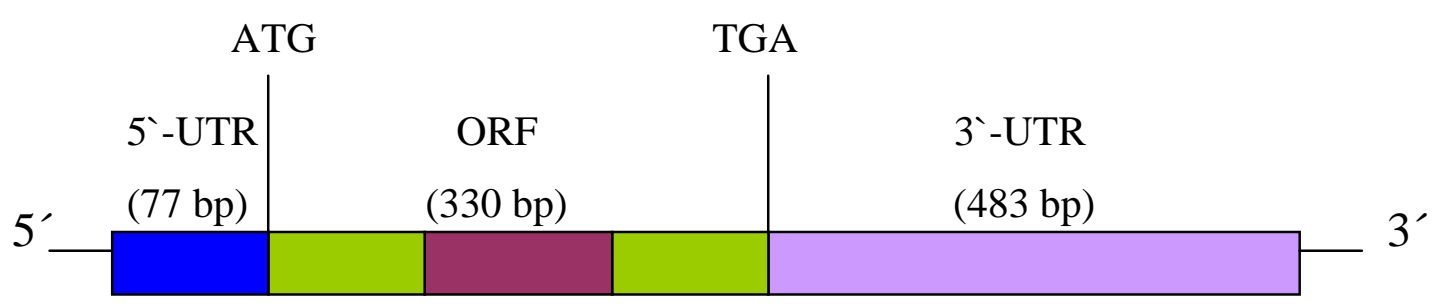

PHD finger domain 
31 gggcggaagttccctaagcttccggctgccggcttggaaaaagagtt

78 ATG GCT AAA CAT CAT CCA GAT TTG ATT TTC TGC CGC $\begin{array}{lllllllllllll}\mathbf{M} & \mathrm{A} & \mathrm{K} & \mathrm{H} & \mathrm{H} & \mathrm{P} & \mathrm{D} & \mathrm{L} & \mathrm{I} & \mathrm{F} & \mathrm{C} & \mathrm{R} & 12\end{array}$

114 AAG CAG GCT GGT GTG GCT ATC GGA AGA CTG TGT GAA $\begin{array}{llllllllllllll}K & Q & A & G & \text { V } & \text { A } & \text { I } & \text { G } & \text { R } & \text { L } & \text { C } & \text { E } & 24\end{array}$

150 AAA TGT GAC GGC AAG TGT GTG ATC TGT GAT TCC TAC $\begin{array}{llllllllllllll}\text { K } & \text { C } & \text { D } & \text { G } & \text { K } & \text { C } & \text { V } & \text { I } & \text { C } & \text { D } & \text { S } & \text { Y } & 36\end{array}$

186 GTG CGT CCC TGC ACC CTG GTC CGC ATA TGT GAT GAG $\begin{array}{lllllllllllll}\mathrm{V} & \mathrm{R} & \mathrm{P} & \mathrm{C} & \mathrm{T} & \mathrm{I} & \mathrm{V} & \mathrm{R} & \mathrm{I} & \mathrm{C} & \mathrm{D} & \mathrm{E} & 48\end{array}$

222 TGT AAC TAT GGA TCT TAC CAG GGC CGG TGT GTA ATC $\begin{array}{llllllllllllll}\text { C } & N & Y & G & S & Y & Q & G & R & C & V & I & 60\end{array}$

258 TGT GGC GGC CCC GGA GTC TCC GAT GCC TAC TAC TGT $\begin{array}{lllllllllllll}\text { C } & \text { G } & \text { G } & \text { P } & \text { G } & \text { V } & \text { S } & \text { D } & \text { A } & \text { Y } & \text { Y } & \text { C } & 72\end{array}$

294 AAA GAG TGC ACC ATT CAG GAG AAg GAT AGA GAT GGT

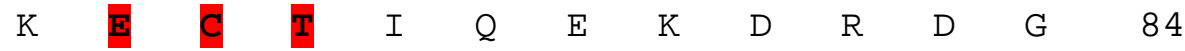

330 TGT CCA AAg ATT GTC AAT TTG GGG AGC TCT AAG ACA $\begin{array}{lllllllllllll}\text { C } & \mathrm{P} & \mathrm{K} & \mathrm{I} & \mathrm{V} & \mathrm{N} & \mathrm{L} & \mathrm{G} & \mathrm{S} & \mathrm{S} & \mathrm{K} & \mathrm{T} & 96\end{array}$

366 GAC CTG TTC TAT GAA CGC AAA AAA TAC GGC TTC AAG $\begin{array}{llllllllllllll}D & \mathrm{~L} & \mathrm{~F} & \mathrm{Y} & \mathrm{E} & \mathrm{R} & \mathrm{K} & \mathrm{K} & \mathrm{Y} & \mathrm{G} & \mathrm{F} & \mathrm{K} & 108\end{array}$

402 AAG AGG TGA tgggtgggtggctccttcctcccccatcaaactgc K R

446 tgcagctgccaatcgcctactaccaccgcctaaagggaacggaget

493 gagtgtcaccagagcagcctgctagtgctagtgtcctggcecctgcc

540 actagcaagtgcccatggagcatctggcagacgggaggagacgttgc

587 tcacttagtccctagttcccttttgttttgagttggaaaagcaagg

534 ctctgttctccacattgatcctttcaactcaaagcctcaaaraag

581 ttggtgtgtgtccttggtaatgaaactgtcccggcagaagtgtggtc

628 ttgcagcagctatgatggggttgtcctgtgaccctcagtgtggccag

675 gtgtgacctgaacagtaatgtgacctgacaatttgtaggtggtgctg

722 ggctcgtgttatttccttgtaagttggaagtttcaattacgctaat

769 aagetggetaccttccccgcc

Fig. 16 (A) Schematic representation of the mouse Pfcp cDNA sequence. (B) The nucleotide and amino acids sequence of mouse Pfcp. The putative polyadenylation signal (AATAAA) is underlined. The start codon "ATG" and the stop codon "TGA" are in bold letters. The conserved amino acids of the PHD finger domain are marked with rot boxes. 


\subsection{Expression analysis of the mouse Pfcp and human PFCP gene}

In order to determine in which mouse tissues and cell lines mouse Pfcp is expressed, Northern blot analysis was carried out. Total RNA was isolated from a range of adult mouse tissues (testis, liver, spleen, brain, kidney, lung, heart, ovary, eye and skeletal muscle), from developmental stages of testis, from testes of mutant mice (olt/olt, ley1l, tfm, qk/qk, w/w and cell lines (GC-1spg, GC-4spc, F9, ES cells, (MA-10) Leydig cells , (15 P1) Sertoli cells), separated on a $1 \%$ horizontal agarose gel, transferred onto a nitrocellulose filter and radioactively hybridized with the 890 bp cDNA of mouse Pfcp probe. The strongest expression of Pfcp was detected in GC-1spg, GC-4spc, F9, ES cells, (MA-10) Leydig cells, (15 P1) Sertoli cells, adult testis, developmental stages of testis, spleen, and mutant mice like $\mathrm{w} / \mathrm{w}^{\mathrm{v}}, \mathrm{tfm}$, ley1l, olt/olt and less stronger expression in kidney, lung, ovary, eye, and skeletal muscle. The size of the transcript was determined as approximately $1.2 \mathrm{~kb}$ by comparison with a RNA size marker (Gibco/BRL) running on the same gel. Integrity and quantification of RNA samples was confirmed by subsequent hybridization of the Northern blot with a $B$-actin probe (Fig. 17). 
A

\section{$\begin{array}{lllllllllll}M & \text { T } & \text { Li } & \text { S } & \text { B } & \text { K } & \text { Lu } & \text { H } & \text { O } & \text { E } & \text { Sm GC-1 GC-4 F9 ES }\end{array}$}

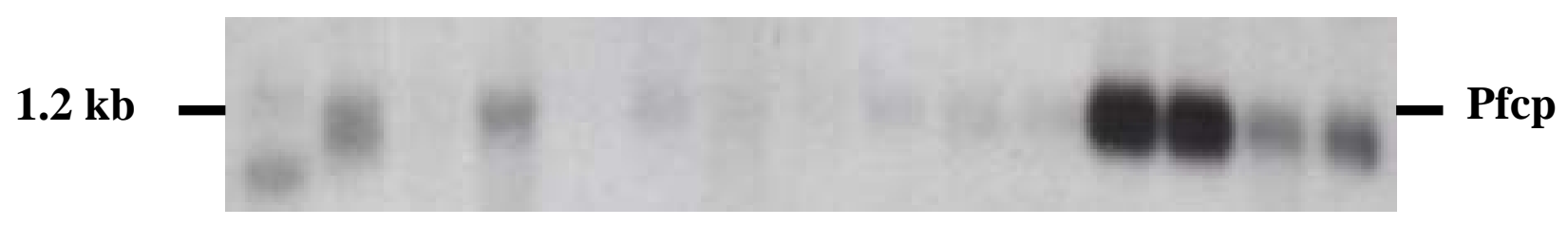

B

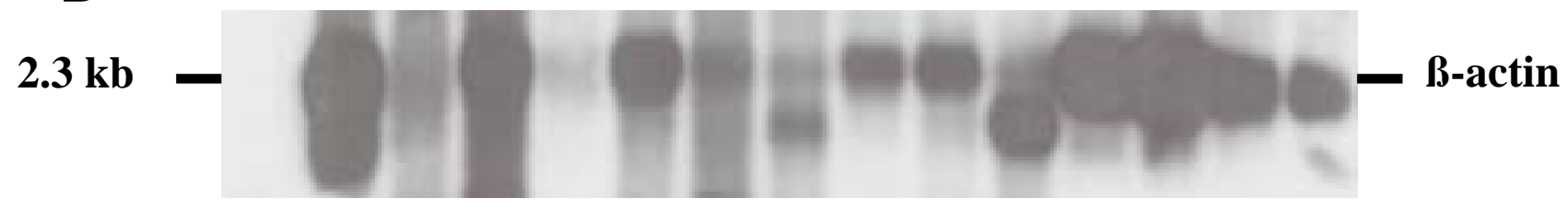

C M olt/olt leyll tfm qk/qk w/w wA-10 $^{v}$ P1 $\quad$ 10d $17 d$ 20d $25 d$ 30d $40 d$

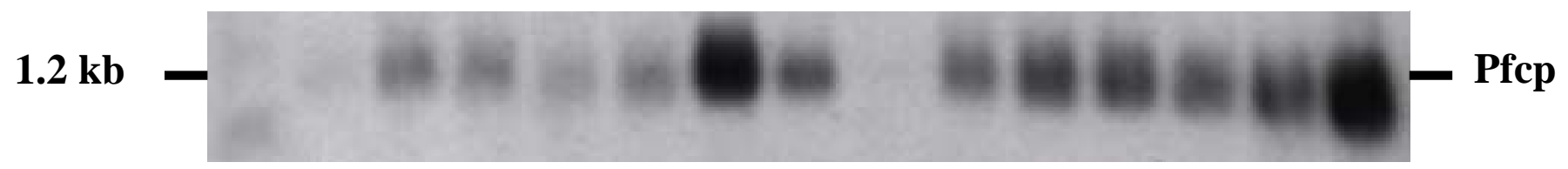

D

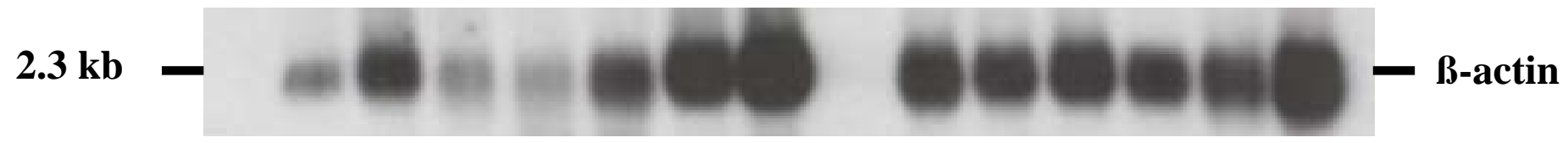

Fig. 17 (A and C) Northern blot analysis of mouse Pfcp. $20 \mu \mathrm{g}$ RNA from different adult mouse tissues (T:testis, Li:liver, SP:spleen, B:brain, K:kidney, Lu:lung, H:heart, O:ovary, E:eye, Sm:skeletal muscle), from different cell lines (GC-1spg, GC-4spc, F9, ES cells, MA-10 (Leydig cells), 15 P1 (Sertoli cells)) and from testes of different mutant mice (olt/olt, ley1l, tfm, qk/qk, $\mathrm{w} / \mathrm{w}^{\mathrm{v}}$ ) and from developmental stages of testes ranging from postnatal day 10 to day 40 were separated by electrophoresis, blotted and hybridized with a 890 bp Pfcp cDNA probe. A transcript of approximately $1.2 \mathrm{~kb}$ was detected. Note strongest expression in GC-1spg, GC-4spc, F9, ES cells, (MA-10) Leydig cells, (15 P1) Sertoli cells, adult testis, developmental stages of testis, spleen and mutant mice $\left(\mathrm{w} / \mathrm{w}^{\mathrm{v}}, \mathrm{tfm}\right.$, ley1l, olt/olt) and less strong expression in kidney, lung, ovary, eye and skeletal muscle. (B and D) Result of rehybridization with a $\beta$-actin probe as control for loading and integrity of RNA. M: DNA length standard. 
To obtain an accurate information about the expression pattern of the human PFCP gene across 76 human tissues, Multiple Tissue Expression $\left(\mathrm{MTE}^{\mathrm{TM}}\right)$ Array analysis was carried out. The MTE Array is a positively charged nylon membrane to which Poly $(\mathrm{A})^{+} \mathrm{RNAs}$ from different human tissues and cancer cell lines have been normalized and immobilized in separate dots, along with several controls. The membrane was hybridized with a $600 \mathrm{bp}$ 5 cDNA ${ }^{32}$ P-labeled PFCP probe. Strong expression of the human PFCP gene was observed in all human tissues and cell lines (Fig. 18 A). As a control for loading and integrity of Poly $(\mathrm{A})^{+}$RNA the filter was rehybridized with an ubiquitin probe (Fig. 18 B).

\section{A Expression pattern of PFCP}

\section{$\begin{array}{lllllllllll}1 & 2 & 3 & 4 & 5 & 6 & 7 & 8 & 9 & 10 & 11\end{array}$}

A

B

C

D

$\mathbf{E}$

$\mathbf{F}$

G

H

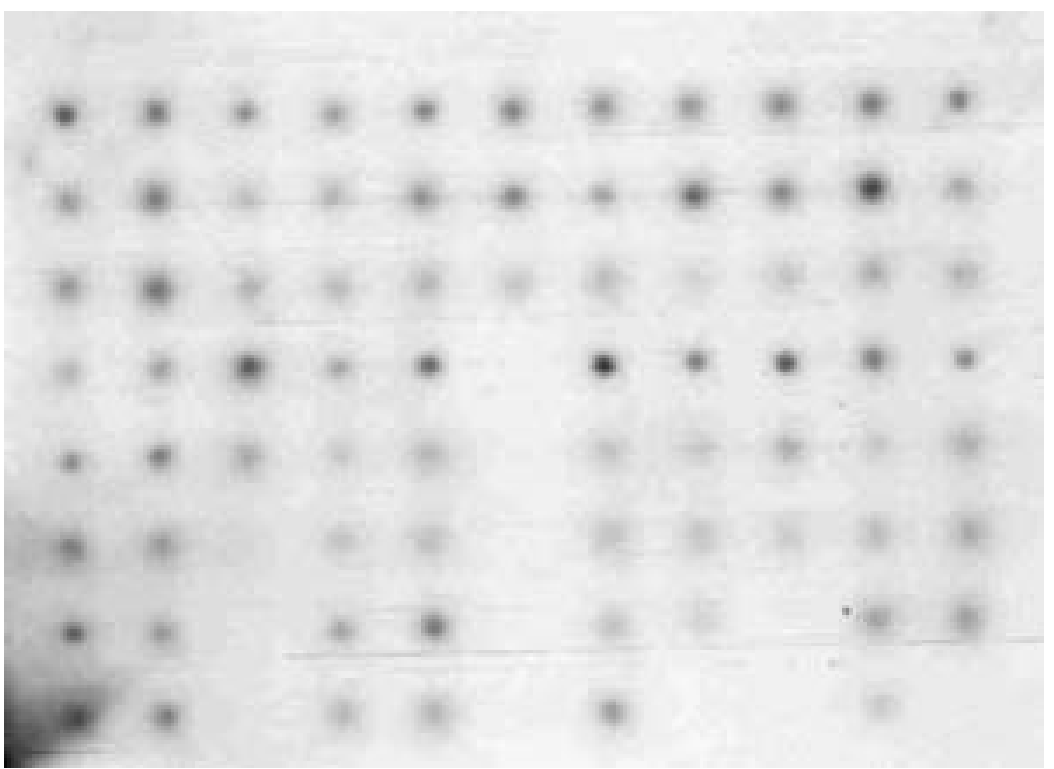


B Expression pattern of ubiquitin

\section{$\begin{array}{lllllllllll}1 & 2 & 3 & 4 & 5 & 6 & 7 & 8 & 9 & 10 & 11\end{array}$}

A

B

C

D

$\mathbf{E}$

F

G

$\mathbf{H}$

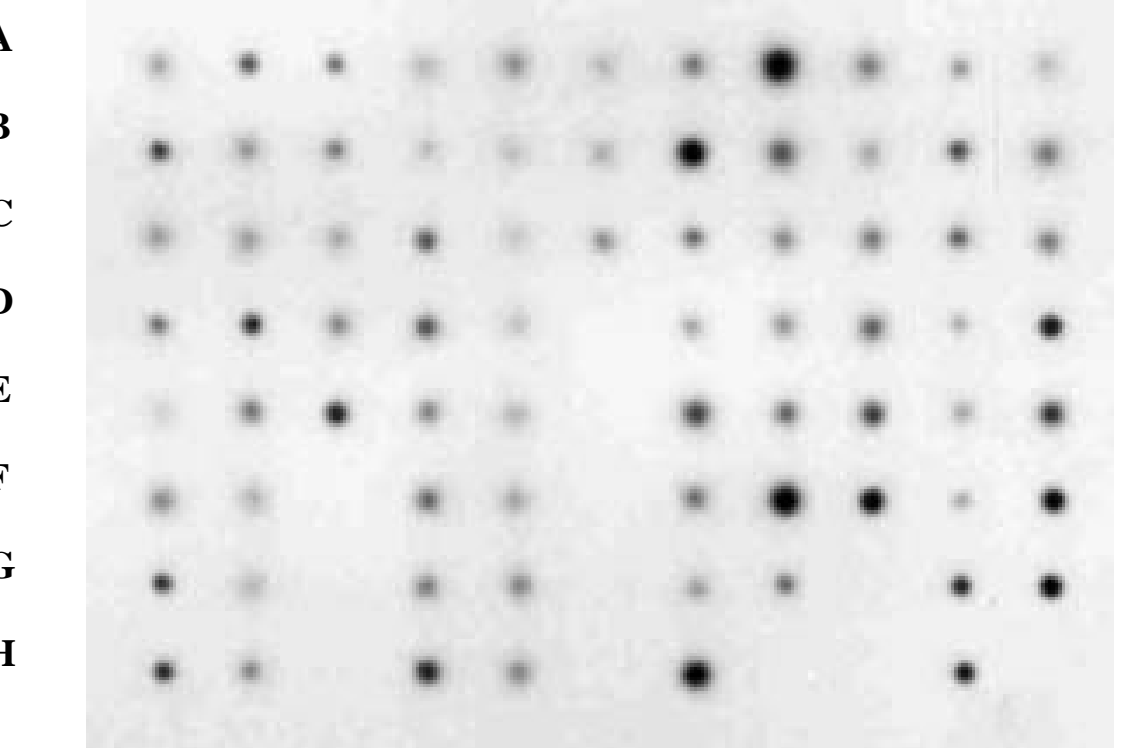

Fig. 18 (A) Expression analysis of the human PFCP gene by using a MTE Array. The prepared membrane which contained Poly $(\mathrm{A})^{+} \mathrm{RNAs}$ from different human tissues and cancer cell lines was hybridized with a $600 \mathrm{bp}$ long 5 probe of the human PFCP gene. Expression of the human PFCP gene was detected in all tissues and cell lines. (B) Result of rehybridization with ubiquitin as a control for loading and integrity of Poly(A) ${ }^{+} \mathrm{RNA}$.

\subsection{Genomic structure and chromosomal localization of mouse Pfcp genes}

By screening a mouse cosmid library from the Resource Center of the German Human Genome Project (RZPD) with a 490 bp long 5 cDNA probe of the mouse Pfcp gene (includes the whole coding region), we obtained approximately 30 cosmid clones. Out of these clones we isolated 12 non-identical genomic cosmid clones containing the entire sequence of four different murine Pfcp genes (cosmids numbers 3, 6, 8 and 10).

By Southern blot analysis $(15 \mu \mathrm{g}$ of mouse genomic DNA was digested with several restriction enzymes, separated on $0.8 \%$ horizontal agarose gel, blotted and hybridized with $490 \mathrm{bp} 5$ 'cDNA probe of mouse Pfcp) several hybridizing restriction fragments were obtained (Fig. 19 ), indicating that the mouse Pfcp gene belongs to a gene family. 


\section{$\begin{array}{llllllllll}M & H & P & X & S t & S f & S s & B & E & A\end{array}$}

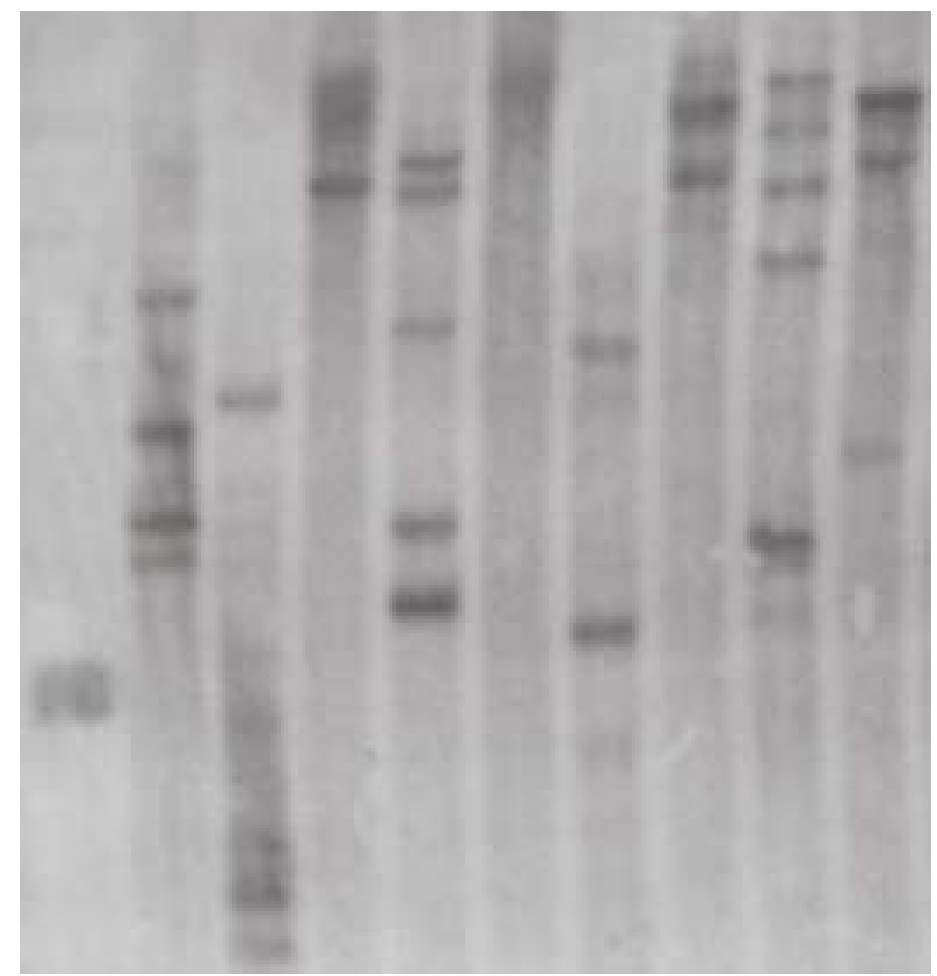

Fig. 19 Southern blot analysis of mouse genomic DNA. $15 \mu \mathrm{g}$ of genomic DNA was digested with several restriction enzymes (H:HindIII, P:PstI, X;XhoI, St:StuI, Sf:SfiI, Ss:SstI, B:BamHI, E:EcoRI and A:ApaI) and hybridized with $490 \mathrm{bp}$ long 5'probe of Pfcp. The observed hybridization pattern is concordant to that of a gene family. M: DNA length standard.

Fluorescence in situ hybridization with four genomic cosmid clones of mouse Pfcp to WMP-1 metaphase chromosomes revealed chromosomal localization of cosmid 8 to chromosome 15, region $\mathrm{F}$, cosmid 10 to chromosome 12, region A-B and both cosmid 3 and 6 to chromosome 13, region D-tel (Fig. 20). 

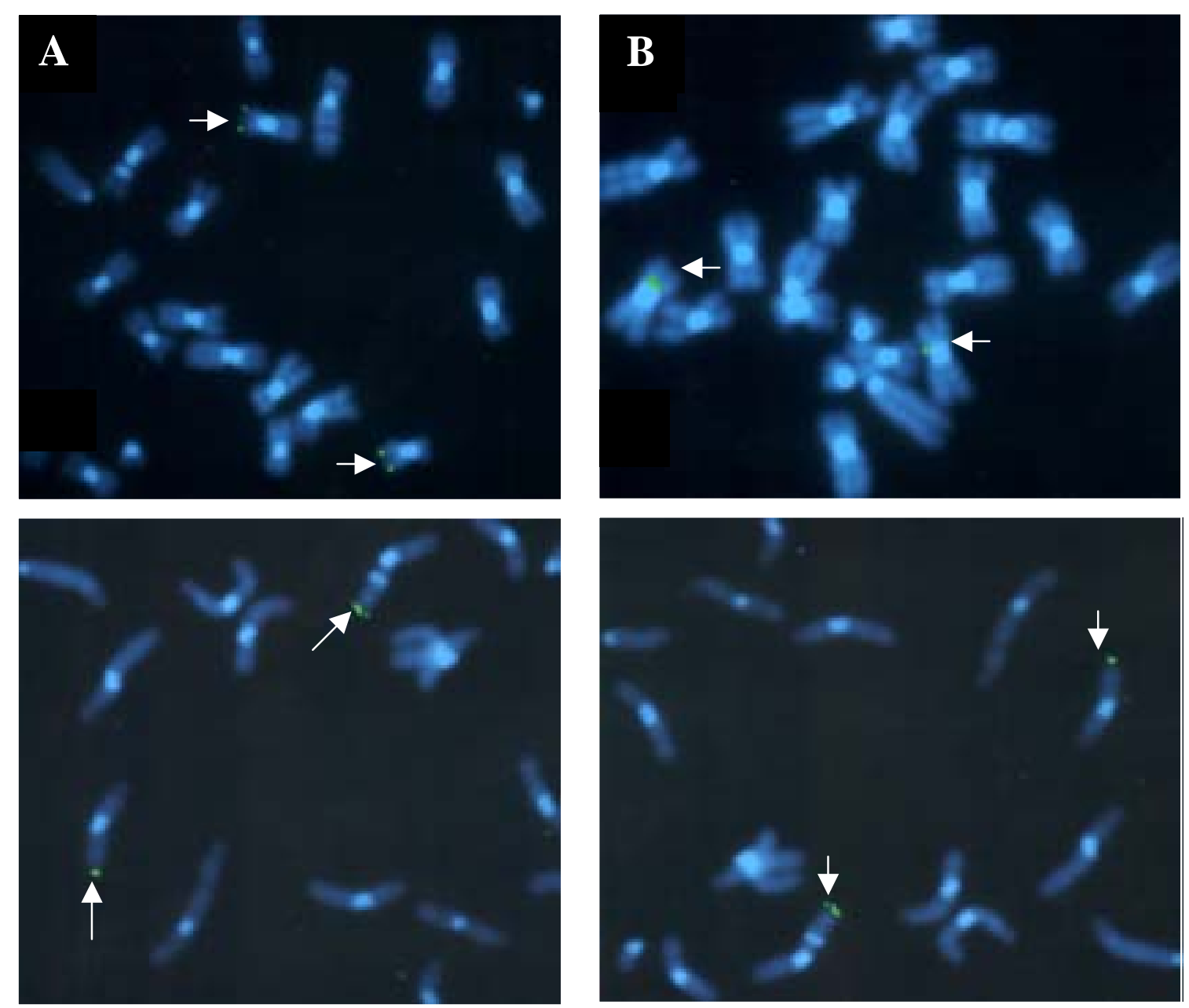

Fig. 20 Chromosomal localization of four different cosmid clones of mouse Pfcp using fluorescence in situ hybridization (FISH) on metaphase chromosomes from WMP-1 murine cells. The arrows point to the specific signals of:(A) cosmid 8 on chromosome 15, region F, (B) cosmid 10 on chromosome 12, region A-B, (C) cosmid 6 on chromosome 13, region D-tel, (D) cosmid 3 on chromosome 13, region D-tel . 


\subsection{Analysis of genomic structures of Pfcp genes}

\subsubsection{Genomic structure of Pfcp.1}

The mouse cosmid clone 8 (localized on chromosome $15 \mathrm{~F}$ ) was digested with different enzymes and hybridized with a 5'cDNA probe of Pfcp including the coding region. The hybridized fragments (subclones pRT6 and pRT11) were isolated and subcloned into pBluescript. Positive clones were sequenced from both sides with vector-specific primers and Pfcp-specific primers. Sequencing results showed that Pfcp.1 (3202 bp) consists of four exons and three introns (Fig. 21).

\section{ATG}

TGA
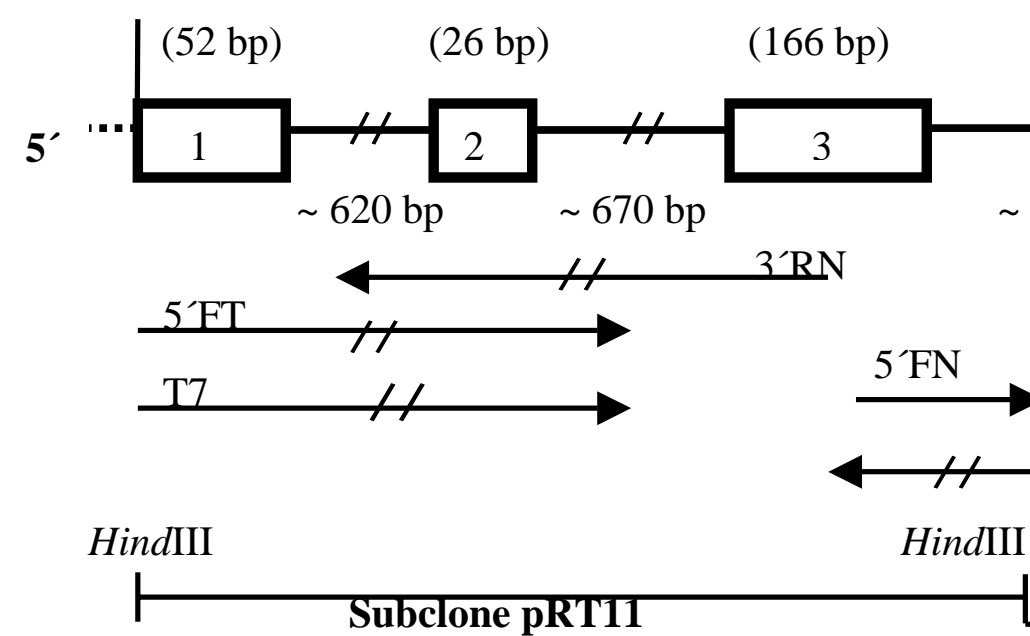

HindIII

Subclone pRT11
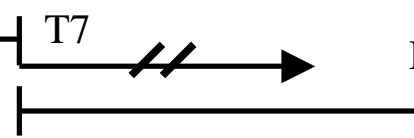

HindIII

Subclone pRT6

Fig. 21 Schematic diagram of the genomic structure of mouse Pfcp.1. The Pfcp.1 gene consists of four exons and three introns. Exons are described as squares and introns as lines. The size of exons and introns are indicated by numbers. The positions of start codon and stop codon are shown. Arrows indicate direction and length of sequencing. pRT 11 and pRT 6 represent organization of positive subclones. 


\subsubsection{Genomic structure of Pfcp.2}

The cosmid clone 10 (localized on chromosome 12 A-B) was digested with different enzymes and hybridized with a 5'probe of Pfcp including the coding region. The hybridizing fragments (subclones pRT8, pRT9 and pRT13) were isolated and subcloned into pBluescript. Positive clones were sequenced from both sides with vector primers and Pfcp-specific primers. Sequencing results showed that Pfcp.2 (760 bp) consists of two exons and one intron (Fig. 22).
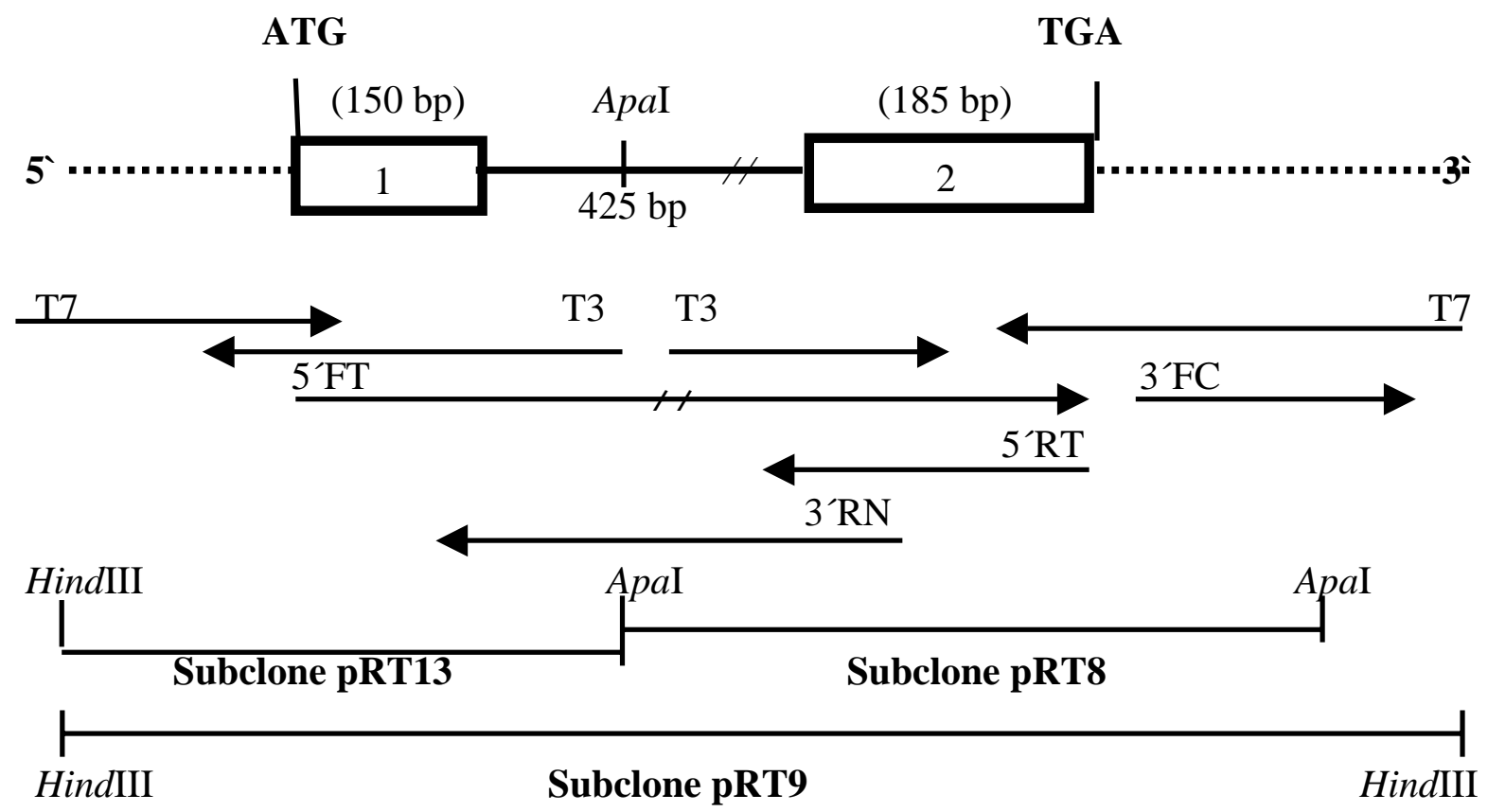

Fig.22 Schematic diagram of the genomic structure of mouse Pfcp.2. The Pfcp.2 gene consists of two exons and one intron. Exons are described as squares and introns as lines. The size of exons and introns are shown by numbers. The positions of the start codon and stop codon are shown. Arrows indicate direction and length of sequencing. pRT 8, pRT 9 and pRT 13 represent organization of positive subclones . 


\subsubsection{Genomic structure of Pfcp.3 and Pfcp.4}

Analyses of the genomic structure for these genes (both localized on chromosome $13 \mathrm{D}$-tel) was performed by PCR using the primers $5^{\prime}$-F.T and $3^{\prime}-\mathrm{R}, 3^{\prime}-\mathrm{R} . \mathrm{N}$ and $5^{\prime}$-R.T on genomic DNA of cosmid clones 3 and 6, respectively. In both genes no intronic sequences were obtained (Fig. 23).

A

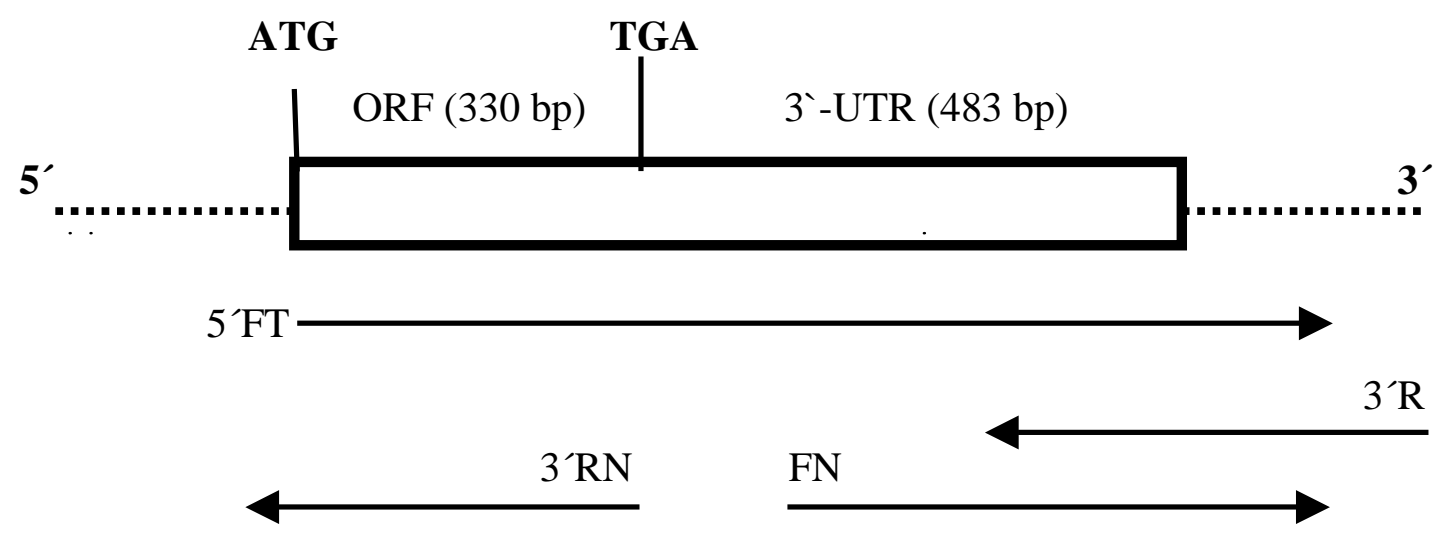

B

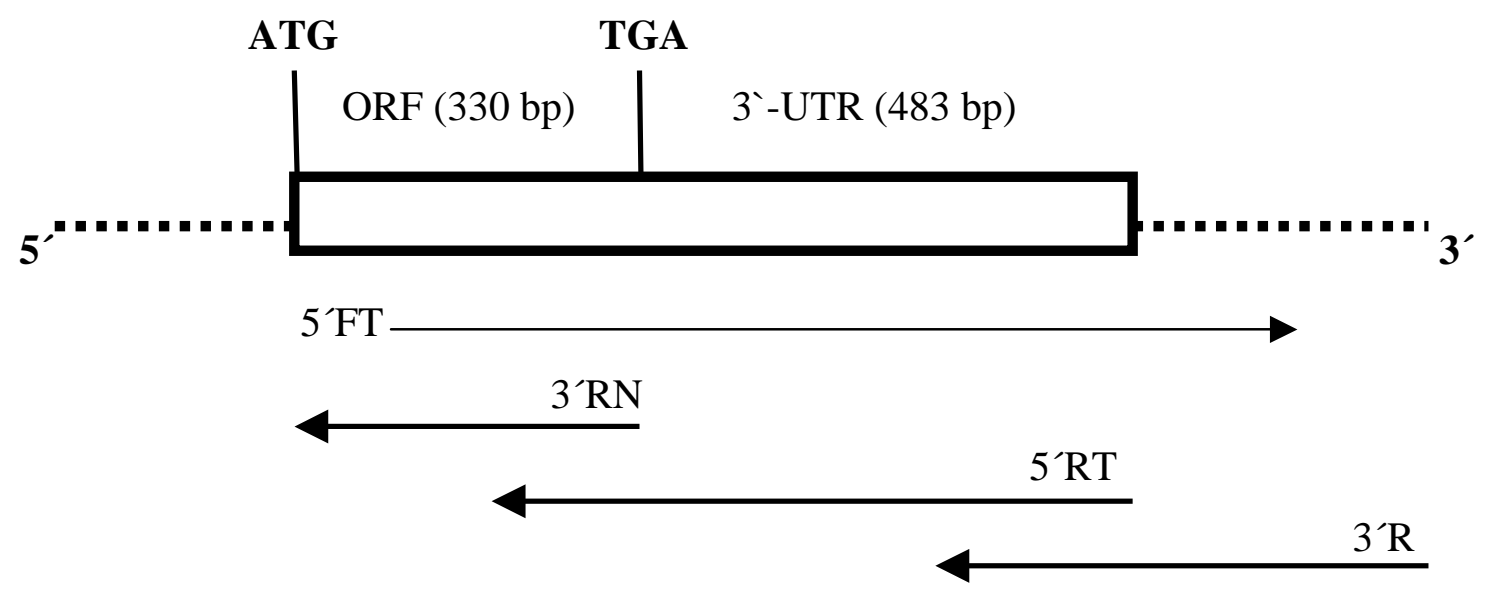

Fig.23 Schematic diagram of the genomic structure of : (A) mouse Pfcp.3. (B) mouse Pfcp.4. There is no intron in both genes. The positions of both the start codon and stop codon are indicated. Arrows indicate direction and length of sequencing.

The sequence of genes Pfcp.1, Pfcp.3 and Pfcp.4 differ from each other respectively by exchange of some amino acids, while the Pfcp. 2 gene shows characteristics of a pseudogene, i.e. in frame stop-codons and frame shifts in exon 1 and 2. 


\subsection{Genomic structure and chromosomal localization of human PFCP genes}

Data base alignment (http://www.ncbi.nlm.nih.gov/blast) with the mouse Pfcp.1 cDNA showed $89 \%$ homology between the cDNA sequence of mouse Pfcp.1 and a human genomic sequence of a BAC clone located on chromosome 22q12.3-13.2 (clone HS223H9, accession No. AL008582). This human PFCP gene consists of four exons and three introns. The complete human PFCP gene spans approximately $5.3 \mathrm{~kb}$ of genomic sequence (Fig. 24).

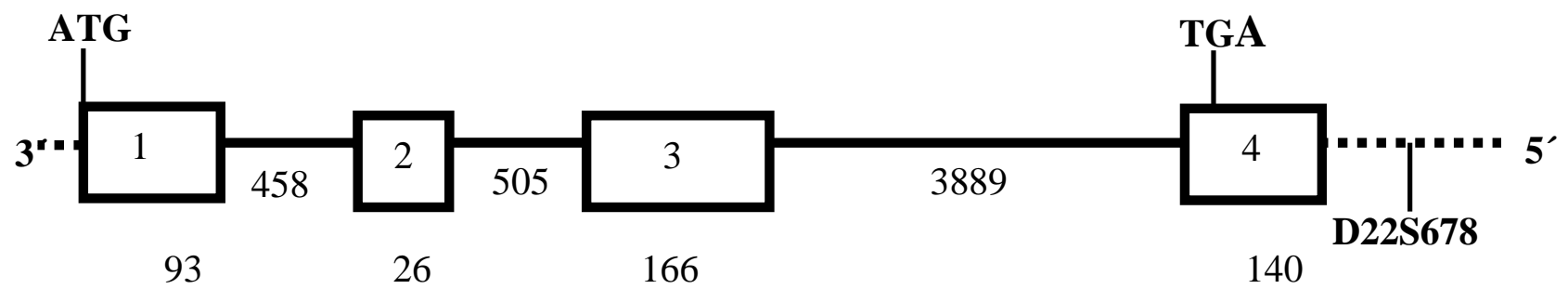

Fig. 24 Schematic diagram of the genomic structure of human PFCP.1. Exons are described as squares and introns as lines. The size in bp of exons and introns are give as numbers. The position of translation-start codon and-stop codon as well as the position of a STS (sequence tagged site)-markers are shown. The human PFCP.1 gene consists of four exons and the complete gene includes approximately $5.3 \mathrm{~kb}$ of genomic sequence.

By using the data base program "electronic PCR" (http://www.ncbi.nlm.nih.gov/genome/sts/ epcr.cgi), we compared this human genomic sequence with known STS (sequence tagged sites) and found the marker D22S678 in the human genomic clone HS223H9. The chromosomal localization of this marker is on chromosome 22q12.3-13.2. All known human EST clones show $100 \%$ homology to the mRNA sequence derived from this gene. Further intronless human PFCP genes were identified on chromosome 2q22.1-q24.2, chromosome 3q23-q24,q13.2, chromosome 19p12-p13.2, chromosome Xq24, chromosome 15q26.2-q26.3 by using a blast search. All these genes show in frame stop-codon-mutations and frame shift mutations. Accordingly, no homologous EST clones were found in the human EST data base encoded by these genes. 


\subsection{Expression analysis for the murine genes Pfcp.1, Pfcp.3 and Pfcp.4}

In order to determine the expression of mouse Pfcp genes in different mouse tissues and cell lines seperately, RT-PCR was carried out. Total RNA was isolated from a range of adult mouse tissues (testis, brain, spleen, liver, kidney, lung, heart, ovary, skeletal muscle and eye) and cell lines GC-1spg, GC-4spc). $1 \mu \mathrm{g}$ RNA from each tissue and cell line and 10 pmol of primers 5'-F and 5'-R.T were used for RT-PCR. We obtained strong expression in all tissues and cell lines (Fig. 25). The size of the product was determined as $330 \mathrm{bp}$ which represents the complete coding region.

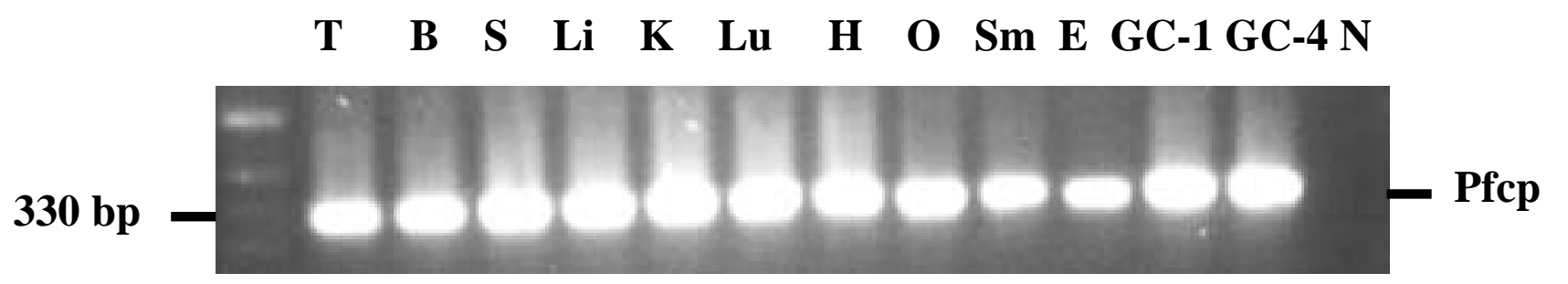

Fig. 25 Expression analysis of mouse Pfcp genes by RT-PCR. RNA was extracted from several adult mouse tissues (T:testis, B:brain, S:spleen, Li:liver, K:kidney, Lu:lung, H:heart, O:ovary, Sm:skeletal muscle and E:eye) and cell lines and assayed for expression of Pfcp by RT-PCR using the primers $5^{\prime}-\mathrm{F} . \mathrm{T}$ and $5^{\prime}$-R.T. N is the negative control $\left(\mathrm{H}_{2} \mathrm{O}\right.$ instead of RNA). There was a strong expression of Pfcp in all mouse tissues and cell lines. The size of the determined product was $330 \mathrm{bp}$ as expected.

In order to differentiate between the expression of different Pfcp genes, the products of adult mouse tissues obtained by RT-PCR were isolated and subcloned into the pGEM-T Easy vector. For each product several subclones were sequenced from both sides with vector specific primers. Sequencing showed a high expression of the Pfcp.1 gene in all mouse tissues analyzed, an expression of the Pfcp. 3 gene in both heart and skeletal muscle, while the expression of the Pfcp.4 gene was found only in lung, kidney, heart and eye (Fig. 26). 


\begin{tabular}{|lclll|}
\hline $\begin{array}{l}\text { Analyzed } \\
\text { tissue }\end{array}$ & $\begin{array}{l}\text { Number } \\
\text { of sequen. } \\
\text { subclones }\end{array}$ & $\begin{array}{l}\text { cDNAs } \\
\text { coding for } \\
\text { Pfcp.1 }\end{array}$ & $\begin{array}{l}\text { cDNAs } \\
\text { coding for } \\
\text { Pfcp.3 }\end{array}$ & $\begin{array}{l}\text { cDNAs } \\
\text { coding for } \\
\text { Pfcp.4 }\end{array}$ \\
Testis & 6 & 6 & - & - \\
Spleen & 6 & 6 & - & - \\
Brain & 8 & 8 & - & - \\
Lung & 7 & 6 & - & 1 \\
Liver & 7 & 7 & - & - \\
Kidney & 7 & 6 & - & 1 \\
Heart & 7 & 5 & 1 & 1 \\
Ovary & 6 & 6 & - & - \\
Muscle & 7 & 6 & 1 & - \\
Eye & 5 & 4 & - & 1 \\
& & & & \\
\hline
\end{tabular}

Fig. 26 Expression analysis of the genes Pfcp.1, Pfcp.3 and Pfcp.4. RT-PCR Products of adult mouse tissues were subcloned and several subclones for each product were sequenced. Sequencing showed an expression of Pfcp. 1 gene in all mouse tissues and expression of the Pfcp.3 gene in heart and skeletal muscle while the expression of Pfcp.4 gene was only found in lung, kidney, heart and eye.

\subsection{Cellular localization of a mouse Pfcp.1-GFP fusion protein in mammalian cells}

Mouse NIH3T3 cells were transiently transfected with a fusion construct containing the complete open reading frame of mouse Pfcp.1 which was coupled to the N-terminus of GFP (green fluorescent protein). After observation under a fluorescence microscope, mouse Pfcp.1 was detected exclusively in the nucleus (Fig. 27). This is in agreement with the results obtained by the computer program PSORT II which predicted the localization of mouse Pfcp. 1 in the nucleus. 

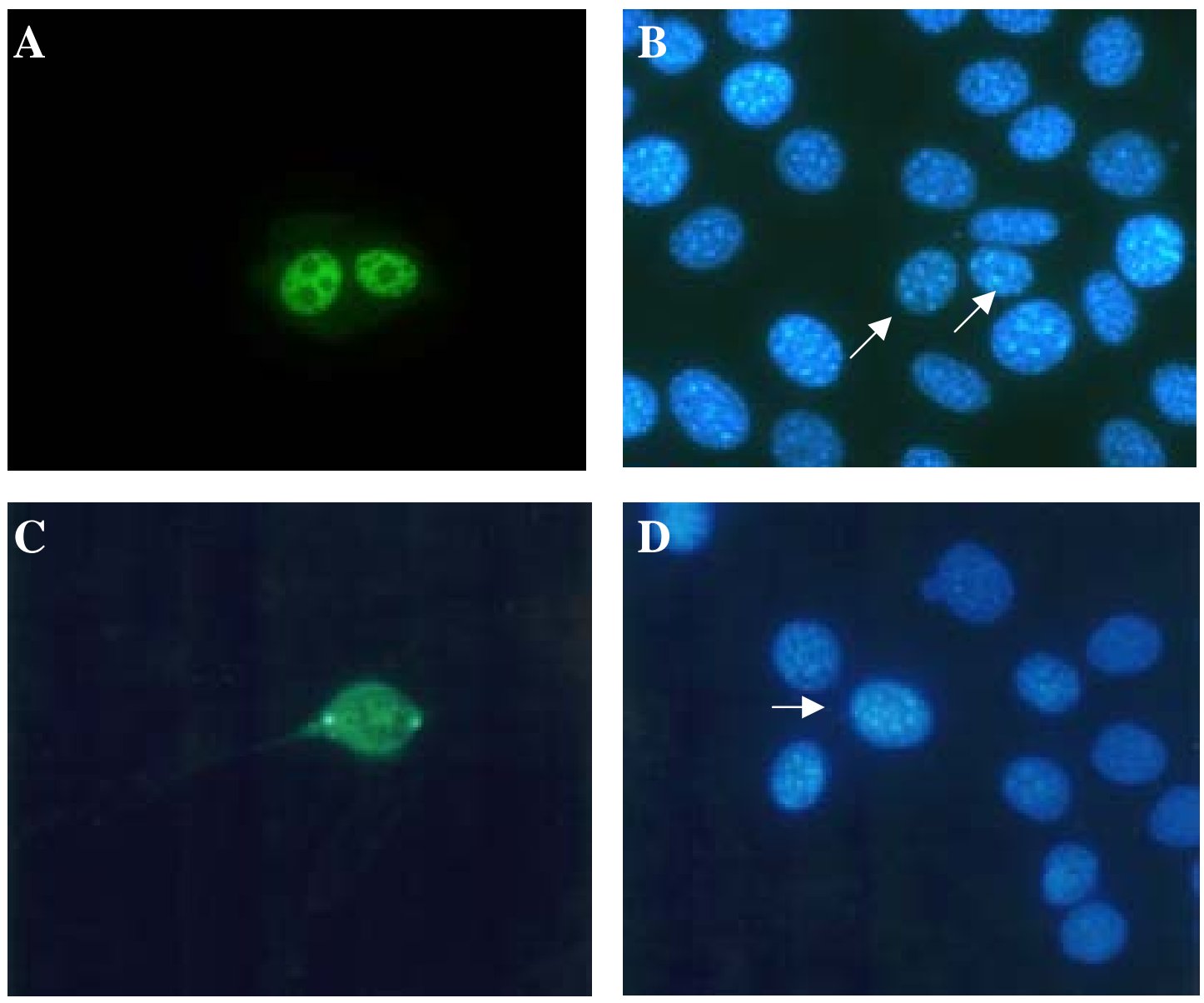

Fig. 27 Localization of Pfcp.1 in mammalian cells. Mouse NIH3T3 cells were transiently transfected with a fusion construct containing the complete ORF of mouse Pfcp.1 and GFP (green fluorescent protein). (A) Irradiation with fluorescent light disclosed a cellular localization of Pfcp.1 in the nucleus. (B) Cell nuclei were counterstained with 4',6'-diamidino-2' phenylindole dihydrochloride (DAPI). (C) As a control mouse NIH3T3 cells were transiently transfected with a plasmid containing GFP only. (D) DAPI-stained nuclei of controltransfected cells. Arrows point to the nuclei of transfected cells.

\subsection{Metaphase arrest}

PHD-finger domains are known to be involved in chromatin binding (Schindler et al., 1993) and were suggested to participate in chromatin mediated transcriptional regulation (Aasland et al., TIBS 1995, 56-59). As the Pfcp.1 protein was shown to be localized in the nucleus of NIH3T3 cells (chapter 3.8) we tried to determine the subcellular localization of the protein and its possible chromatin binding capacity. For this purpose NIH3T3 cells were seed on cell culture slide flask and were transiently transfected with the Pfcp.1-GFP-fusion construct as described. Afterwards the cells were cultured for 24 hours to allow appropiate protein synthesis of the Pfcp.1-GFP-fusion protein and were then treated for further 24 hours with 
low concentrations of colcemid to arrest cells in the metaphase of the cell cycle. After a fixation step DAPI staining was performed to analyse the efficency of the metaphase arresting procedure and all metaphase arrested NIH3T3 cells were analyzed for the presence of GFPfluorescence. Typically 10-20\% of the NIH3T3 were at metaphase after 24 hours of colcemid treatment. Extension of the colcemid coincubation time or the colcemid concentration lead to an excessive cell death and was therefore inappropiate for an enlargment of the percentage amount of metaphase arrested cells. While about only $5 \%$ to $10 \%$ of the NIH3T3 cells were successfully transfected with the Pfcp.1-GFP DNA-plasmids only up to $1 \%$ of all cells were positive for both criteria. In these cells (as shown in Fig. 28) the GFP-fluorescence signal matches the signal derived by DAPI staining, giving evidence of the localization of Pfcp.1 to chromatin structures.
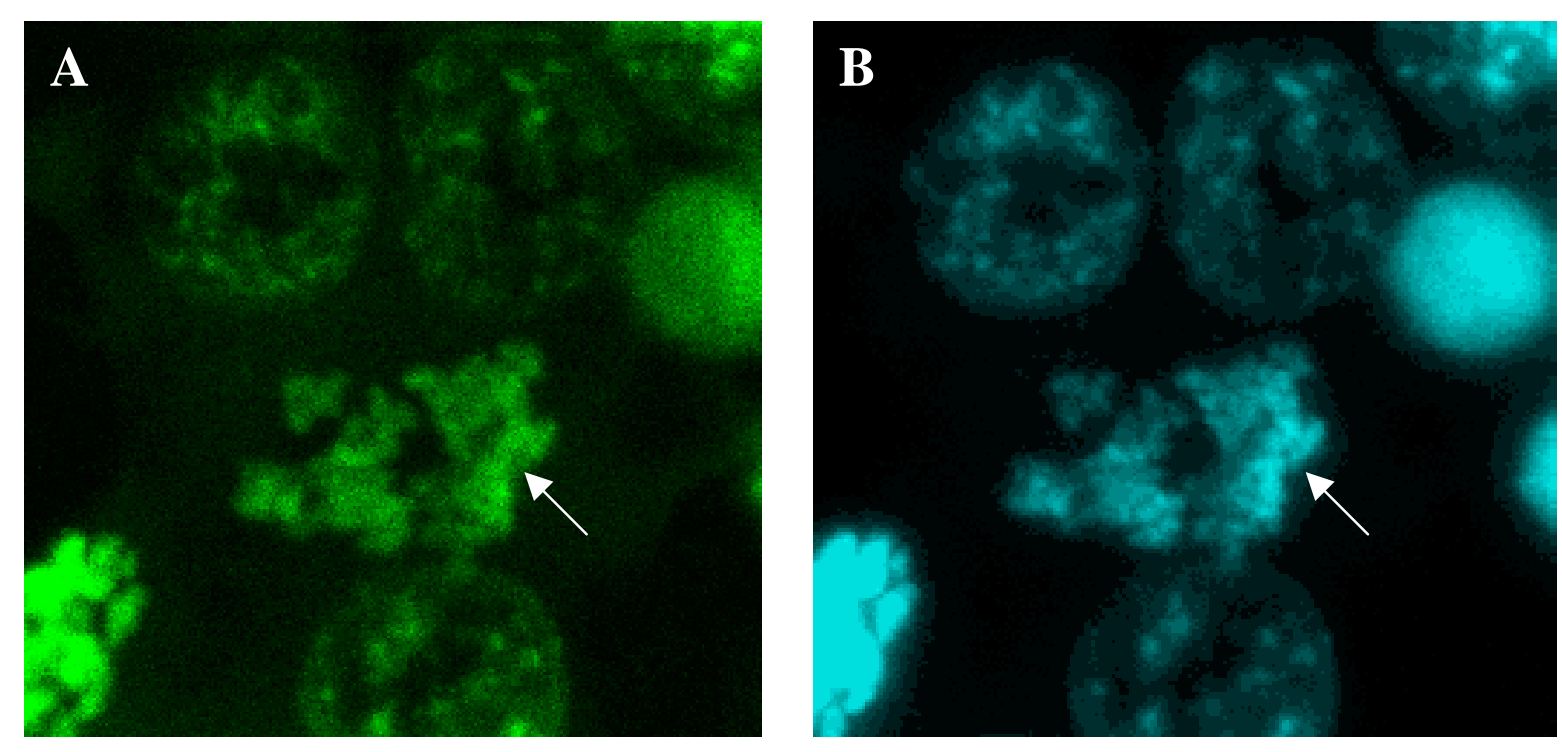

Fig.28 Localization of Pfcp in mammalian cells. Mouse NIH3T3 cells were transfected with a fusion construct containing the complete ORF of mouse Pfcp.1 and GFP. (A) Cellular localization of Pfcp.1 in the chromatids. (B) DNA counterstaind with DAPI. 


\section{DISCUSSION}

\subsection{Summary of the results}

Cell-type specific tumorigenesis can be induced in transgenic mice by the directed expression of simian virus 40 (SV40) large tumour antigen (LTA). In an attempt to determine the susceptibility of primordial germ cells (PGCs) to neoplastic transformation, transgenic mice were generated which harboured the oncogene SV40 large T antigen fused to the $1.7 \mathrm{~kb}$ 5 flanking sequences of the human GCAP gene as a promoter. Three independent transgenic lines were generated. RT-PCR analysis showed testis specific expression of LTA in the adults of both heterozygous and homozygous transgenic mice of at least one transgenic line. Furthermore, we could detect LTA mRNA in 8.5 dpc prenatal embryos of transgenic mice. However, even after a period of about 20 months, no tumor was observed in any organ of these mice.

Using an "in vitro" approach of analysing differentially expressed genes in GC-1spg cells through suppression subtractive hybridization ( $\mathrm{SSH}$ ), a so far unknown gene was found to be highly expressed in invasive GC-1spg cells. We named this gene Pfcp (PHD-finger-like chromatin proteins) as the deduced protein sequence shows a domain known as "PHD-finger" like domain, known to be involved in chromatin binding. The cDNA sequence of mouse Pfcp was isolated and analyzed as well as its genomic structure. The expression pattern of mouse Pfcp and its cellular and subcellular location were determined.

\subsection{The susceptibility of primordial germ cells to malignant transformation}

It has been shown that transgenic mice bearing various sequences of the simian virus 40 LTA offer a model system to study the multi-stage process of neoplasia. In conjunction with a variety of cell type-specific transcriptional regulatory elements, directed expression of LTA in transgenic mice often leads to tissue-specific neoplasia (Brinster et al., 1984; Thomas et al., 1996; Bosse et al., 1997; Wikenheiser et al., 1997).

Understanding the mechanisms of male germ cell tumor development has considerable relevance for understanding normal germ cell development, mechanisms of germ cell transformation, as well as the regulation of embryonic differentiation pathways in mammals. 
It has been shown that human and murine germ cell tumors share certain features reflecting their germ cell origin,i.e., pluripotentiality, expression of wild-type p53 and sensitivity to DNA-damaging agents. These features make murine models an attractive system for the analysis of these phenomena. Up to now two models for human germ cell tumors have been described by Stevens (1970) and Meng et al., (2001). Stevens discovered that testicular teratomas can be experimentally produced from primordial germ cells in mice of strain 129/sv and their F1 hybrids by grafting 12- and 13-day fetal genital ridges into histocompatible adult testes. Meng et al. showed that targeted overexpression of the glial cell line-derived neurotrophic factor (GDNF) in undifferentiated spermatogonia promotes malignant testicular tumors in transgenic mice.

To study the susceptibility of PGCs to malignant transformation we developed a further transgenic mouse model. In our model we used the oncogenic activity of SV40 large T antigen. Using the specific promoter activity of human germ cell alkaline phosphatase (GCAP) in PGCs, we directed SV40 LTA expression to PGCs and early spermatogonia. Three transgenic mice were generated. RT-PCR analysis from testis of transgenic mice revealed LTA expression in testicular tissues. Expression analysis of transgenic animals during prenatal development has shown LTA expression as early as $8.5 \mathrm{dpc}$ indicating LTA expression during germ cell development.

Human germ cell alkaline phosphatase (GCAP) is normally produced in primordial germ cells during embryogenesis and in trace amounts in adult testis and thymus. The equivalent mouse isozyme, embryonic alkaline phosphatase (EAP), is similarly expressed in the testis and thymus but also from the 2-cell to blastocyst stage of preimplantation development. This expression pattern resembles that found for the human GCAP isoenzyme. Therefore, similar functions have been proposed for EAP and GCAP in the testis. EAP has been found to be transiently expressed in M-phase spermatogenic cells in the mouse testis. These alkaline phosphatase isozymes serve as markers of germ cell differentiation and in the management of germ cell tumors. GCAP is overexpressed in carcinoma-in-situ and seminoma where serum GCAP levels are often elevated (Hofmann et al., 1993; Hofmann et al., 1989).

Germ cell tumors are a rather heterogeneous group of neoplasms. They account for more than $90 \%$ of testicular tumors (Damjanov, 1991) and are the most frequent form of cancer in males between 15 and 34 years of age. While $\alpha$-fetoprotein and human chorionic gonadotropin are well-established markers for the nonseminomatous germ cell tumors (Koshida et al., 1991), there is to date no tumor marker suited for the diagnosis and follow-up of seminomas, which account for approximately $40 \%$ of testicular germ cell tumors (Koshida et al., 1990). 
Numerous associations have been reported between the expression of GCAP and malignancy, particularly in testicular seminoma, cancer of the ovary, and the uterus. The aberrant expression of GCAP genes in cancer cells has led to the suggestion that GCAP is a oncofetal protein and thus could be involved in tumorigenesis (Millan et al., 1995 ; Millan, 1992). Enhanced GCAP expression is not only found in seminoma but also in the precancerous stage common to all germ cell tumors. Germ cell tumors, with the only exception of spermatocytic seminoma, are preceded by a noninvasive form of neoplasia, known as CIS. Progression from CIS to invasive cancer was observed in $70 \%$ of the cases within 7 years of observation, and it is believed that all cases of CIS will develop to invasive cancer. Regression of CIS has not been observed in testes of men.

Wada et al., (1993) showed a comprehensive analysis of the cis-acting regulatory sequences in the 5 'flanking region of the GCAP gene which are responsible for its expression in human choriocarcinoma cells. They show that the -156 to -1 - bp region upstream of the transcription initiation site of the GCAP gene contains activation elements essential for its expression. Furthermore, there are transcription factors present in choriocarcinoma cells that bind to the GCAP promoter elements. Mutagenesis studies delineate the core DNA sequence essential for the expression of GCAP in human choriocarcinoma cells.

Up to now, no tumor was detected in any organ of GCAP-LTA transgenic mice. This may be due to the following reasons: 1) The transcription level of LTA is not sufficient to induce tumor development from PGCs. As we couldn't detect a LTA transcript by Northern blot analysis it may be that the used $1.7 \mathrm{~kb}$ fragment of the human germ cell alkaline phosphatase (GCAP) promoter is not sufficient to direct a strong expression of large T antigen in vivo. A further possibility for a low expression level is the integration of transgene in an inactive chromatin region. 2) Proliferation of PGCs are under strong control due to the cell-cell interaction and hormonal and molecular regulations. It is therefore possible that large $\mathrm{T}$ antigen protein is inactive in this cell type. In some cell types, proliferation and differentiation could be incompatible for mechanistic reasons, for instance, the loss of elements essential for cell division in differentiated cells. However, in most cases evidence is accumulating in favour of a controlled switch between both processes. The regulatory interactions which lead to the choice between cell division and differentiation are only beginning to become unraveled. Expression of many genes included those which are necessary for SV40 LTA immortalizing and transforming activities may be downregulated. 
Stevens (1970) demonstrated that teratomas can be experimentally produced easily in the testes of strain $\mathrm{A} / \mathrm{He}$ and in $129 \mathrm{X} \mathrm{A} / \mathrm{He}$ hybrids. When genital ridges of 12- and 13-day strain $\mathrm{A} / \mathrm{He}$ fetuses were grafted to the testes of adults, the male grafts developed into testes and many had teratomatous foci. The incidence of teratomas in hybrids was higher when the mother was of strain 129, indicating a maternal influence on teratocarcinogenesis. Preliminary results indicate that some, e.g., $\mathrm{A} / \mathrm{He}$ and 129, have a high susceptibility, some have a low susceptibility, and some are resistant to experimental teratocarcinogenesis. These strain differences indicate that a strong genetic component is involved.

Glial cell line-Derived Neurotrophic Factor (GDNF) is a distant member of the transforming growth factor- $\beta$ superfamily (Lin et al., 1993). GDNF is expressed in the testis by Sertoli cells, the paracrine regulators of spermatogenesis, whereas the GDNF receptors are being expressed by undifferentiated spermatogonia (Meng et al., 2000). Meng et al. (2001) showed that targeted overexpression of GDNF in undifferentiated spermatogonia of transgenic mice promotes malignant testicular tumors, which express germ cell markers. The tumors are invasive and contain aneuploid cells, but no distant metastases have been found. By several histological, molecular and histochemical characteristics, the GDNF-induced tumors mimic classic seminomas in men, representing a useful experimental model for testicular germ cell tumors. The data also show that a deregulated stimulation of a normal proto-oncogene by its ligand can be an initiative event in carcinogenesis.

Spontaneous seminomas are extremely rare in animals (Mitsumori et al., 1988). Although seminomatous tumors have been reported in mice, dogs, rams, bucks, rabbits and possibly bulls, almost invariably these tumors have been characterized as spermatocytic seminomas (Veeramachaneni et al., 1999). In contrast, the morphology, histochemical and molecular characteristics and aneuploidy of the GDNF-induced tumors are similar to human classical seminomas. Thus, these mice represent the first transgenic animal model for this tumor type that is the most common TGCT in men. It was shown recently that GDNF and its receptors are expressed by human seminomas (Viglietto et al., 2000), but their role in the pathogenesis of the human testicular tumors remains to be established.

\subsection{Characterization and functional examination of mouse Pfcp, overexpressed in GC-1spg cells}

In recent years several murine male germ cell lines at a defined stage of spermatogenesis have been established using the 'immortalizing' properties of the SV40 large T antigen. One of 
these immortalized germ cell lines, GC-1spg, was characterized as a germ cell line that could be identified as intermediate between type B spermatogonia and preleptotene spermatocyte, based on its characteristics in phase contrast and electron microscopy. This cell line expresses the testicular cytochrome $c_{t}$ and lactate dehydrogenase- $C_{4}$ isozyme (Hofmann et al., 1992). The immortalized GC-1spg germ cells are weakly positive cytochemically for AP, whereas normal spermatogonia and preleptotene spermatocytes in the prepuberal testis are usually AP negative except for the transitional presence of EAP in M-phase spermatocytes (Narisawa et al., 1992). In agreement, RT-PCR analysis of GC-1spg revealed the predominant presence of EAP mRNA in this line. Thus, the analysis of expression of AP isozymes in immortalized testicular cell lines confirm the observations made on freshly isolated germ cell tumors: the enhanced production of APs and particularly the ectopic expression of tissue specific alkaline phosphatase (TSAP) genes accompanying a transformed status. A second immortalized germ cell line termed GC-4spc has been characterized as a germ cell line arrested between the preleptotene spermatocyte and the early pachytene spermatocyte (Tascou et al., 2000). It is generally assumed that the process of immortalization by large $\mathrm{T}$ antigen represents a first step toward cell transformation (Hamburger et al., 1977). In an attempt to elucidate the potential of premeiotic male germ cells to malignant transformation, we compared the spermatogonia (GC-1spg) and spermatocyte (GC-4spc) cell lines of the mouse in an in vitro martigel assay Tascou et al. (2001). We found out that only the spermatogonia cell line showed a remarkable invasive potential in this assay. Furthermore, using RT-PCR analysis, we demonstrated that the expression of endogenous embryonic alkaline phosphatase is upregulated in the invasive spermatogonia cell line. These results indicate that the transformation potential of premeiotic germ cells in vitro depends on the degree of differentiation and that the expression level of tumor marker germ cell alkaline phosphatase is associated with stage of transformation. In a SCID mouse model we demonstrated that immortalized spermatogonia and immortalized spermatocytes show different tumorigenesis pattern. The cell lines GC-1spg and GC-4spc may be considered as precancerous and represent a valuable model to study the molecular origin of testicular germ cell tumors in vitro. In order to compare the expression level of both cell lines and to isolate differentially expressed genes, a suppression subtractive hybridization ( $\mathrm{SSH}$ ) between the two cell lines was performed. Several clones were isolated and further analyzed.

One of these differentially expressed genes, termed Pfcp was found to be highly expressed in the spermatogonia-derived cell line GC-1spg as compared to the expression in the 
spermatocyte-derived cell line GC-4spc. Pfcp therefore is a putative candidate gene which might be involved in the process of transformation of GC-1spg cell line (Tascou et al., 2001). The initial 890 bp cDNA fragment from the 3'-UTR of mouse Pfcp was isolated through SSH. The Pfcp cDNA consists of a 5' UTR of 77 bp and an ORF of 330 bp encoding a protein of 110 amino acids. The 3' UTR consists of $483 \mathrm{bp}$ and contains a putative polyadenylation signal (AATAAA). Northern blot analysis showed one transcript at approximately $1.2 \mathrm{~kb}$. Screening a mouse cosmid library and a genomic Southern blot using a $490 \mathrm{bp}$ long 5'probe of Pfcp showed the typical pattern of a gene family which consists of four different murine Pfcp genes (family of PHD finger).

\subsection{The PHD finger}

The family of PHD fingers may recognize a set of similar nuclear targets related to chromatin structure and chromatin regulation, such as the differentially modified tails of the nucleosomal histones (Aasland et al., 1995). The PHD motifs are contained within Cys-rich regions that were, in some cases (such as trx), suggested to be classical DNA-binding zinc fingers (Mazo et al., 1990). Schindler et al. (1993) noted this Cys-rich motif in two closely related plant homeodomain proteins, HAT3.1 and HOX1A, and called it the PHD finger (plant homeodomain-finger). Homeodomain proteins have been shown to play a major role in the development of various organisms (Schindler et al., 1993). One of the best characterized DNA binding domains is the homeodomain found in many key regulatory proteins of Drosophila, mouse, humans and various other organisms (Laughon, 1991; Scott et al., 1989). This DNA binding domain is encoded by an approximately $180 \mathrm{bp}$ region termed the homeobox. Detailed structural studies of two homeodomain-DNA complexes revealed that the homeodomain is composed of three $\alpha$-helical regions (helix 1, 2 and 3). Based on amino acid sequence similarities, homeodomains can be classified into individual families (Laughon, 1991; Scott et al., 1989). Some of these families are characterized by additional conserved protein motifs that facilitate DNA binding and/or protein-protein interactions (Freyd et al., 1990; Ingraham et al., 1990; Karlsson et al., 1990; Treisman et al., 1991; Voss et al., 1991). Schindler et al. (1993) suggested that the N-terminal cysteine-rich domain represents a novel protein motif strongly conserved in plant homeodomain proteins. The regular spacing of the cysteine and histidine residues implies that this motif could function as a metal binding domain (Berg, 1990; Luisi, 1992). 
DNA binding studies with Drosophila proteins demonstrated that single homeodomains interact with a variety of DNA sequences in vitro and rather different homeodomains were able to bind the same DNA motif (Desplan et al., 1988; Hoey and Levine, 1988a, 1988b). Similarly, the affinity by which homeodomains interact in vitro with their cognate recognition sequence is often relatively low which may be a consequence of the fact that homeodomain proteins usually bind as monomers to their cognate recognition sequence (Affolter et al., 1990). However, homeodomain proteins in vivo often act synergistically and the in vivo DNA binding site requirements may be more stringent than the ones observed in vitro (Han et al., 1989; Jiang et al., 1991; Stern et al., 1989; Vincent et al., 1990).

Two PHD fingers are encoded by the human X-linked gene XE169 (and by its mouse homologues, Smcx and Smcy), a gene that escapes X inactivation (Agulnik et al., 1994; Wu et al., 1994). Br140, a nuclear protein with a bromodomain (Thompson et al., 1994), also contains one PHD finger. PHD fingers were detected in several other putative transcription factors as well as in a number of poorly characterized sequences, including several expressed sequence tags (ESTs).

\subsection{The homology between protein sequences of Pfcp in different species}

Data base alignment showed the strongest protein homology of mouse Pfcp to human bk223H9.2 (ortholog of A.thaliana F23F1.8) (Accession No. AL008582) with 100\% amino acid identity and homology to Drosophila CG9548 gene product (Accession No. AE003613) with 95\% amino acid identity. Other homologous proteins from the flowers are the hypothetical protein F23F1.8 (Arabidopsis thaliana) (Accession No. AC004680) with 92\% amino acid identity. Proteins from yeast like the hypothetical protein SPAC23H3.02c from Schizosaccharomyces pombe (Accession No. Z99163) show 70\% amino acid identity, the hypothetical protein YPR094w from Saccharomyces cerevisiae (Accession No. US1033) shows 56\% amino acid identity to mouse Pfcp (Fig. 29).

\footnotetext{
Ar.th. MAKHHPDLIMCRKQPGIAIGRLCEKCDGKCVICDSYVRPCTLVRICDECNYGSFQGRCVI 60 mouse MAKHHPDLIFCRKQAGVAIGRLCEKCDGKCVICDSYVRPCTLVRICDECNYGSYQGRCVI 60 Human MAKHHPDLIFCRKQAGVAIGRLCEKCDGKCVICDSYVRPCTLVRICDECNYGSYQGRCVI 60 Drosophila MAKHHPDLIFCRKQPGVAIGRLCEKDDGKCVICDSYVRPCTLVRICDECNYGSYQGRCVI 60 Fis.yeast MSKHHPDLVLCRRQPGITVGKLCERCDEKCPICDSHVRPTTLVRICDECAFGSSQDRCII 60 Yeast MSRHQFDLIMCLKQPGVQTGLLCEKCDGKCP ICDSYVRPKRKVRVCENCSFGKQAKNCII 


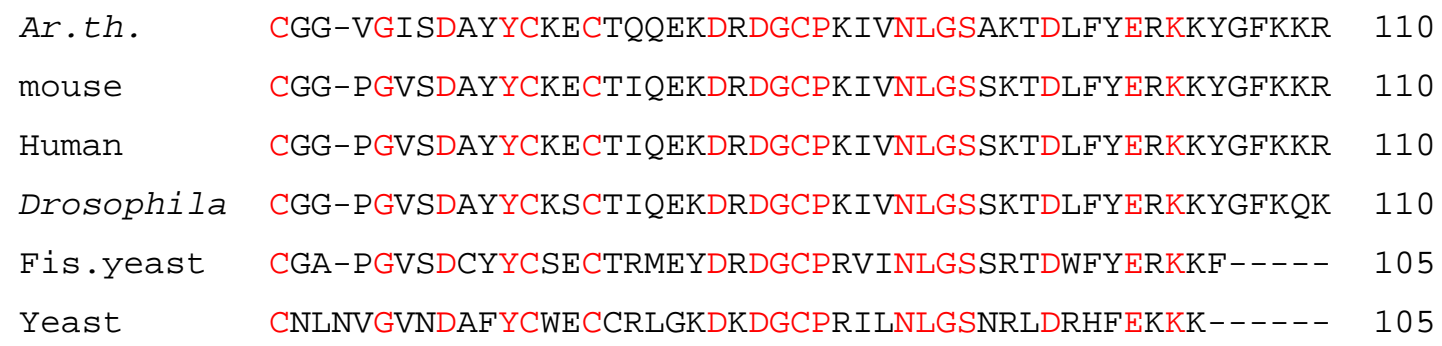

Fig. 29 Multiple amino acid sequence alignment of mouse Pfcp and different species with homologous proteins, e.g. human bk223H9.2 (Accession No. AL008582), Drosophila CG9548 (Accession No. AE003613), hypothetical protein F23F1.8 (Accession No. AC004680), fission yeast SPAC23H3.02c (Accession No. Z99163) and yeast YPR094w (Accession No. US1033). The identical amino acids are given in red.

\subsection{Expression analysis of the mouse Pfcp and human PFCP}

Northern blot analysis of the mouse Pfcp with RNA from different mouse cell lines showed strongest expression in the GC-1spg cell line. The ubiquitous expression of Pfcp could be detected in different mouse tissues by using Northern blot analysis. RT-PCR analysis with RNA from multiple postnatal mouse tissues and different cell lines confirmed an overall expression of Pfcp. However, we could detect an expression of Pfcp gene in embryonic stem cell and also in different developmental stages of testes ranging from postnatal day 10 to day 40. Furthermore, we could detect an expression in different mutant mice, so we showed an expression in both Leydig and Sertoli cells.

In order to differentiate between the expression of different Pfcp genes, RT-PCR was carried out. We could detected an expression of the Pfcp.1 gene in all mouse tissues and an expression of the Pfcp.3 gene in two mouse tissues (heart and skeletal muscle) while the expression of the Pfcp.4 gene was found in four mouse tissues (lung, kidney, heart and eye). The expression analysis of human PFCP using a MTE Array detected PFCP expression in all human tissues and all analyzed cancer cell lines.

From this ubiquitous expression pattern of the Pfcp genes, we suggest a fundamental function of this genes in all cell types. A suggestion that is further underlined by the fact of an enormous evolutionary conservation of these genes.

\subsection{Cellular localization of Pfcp}

Through GFP, the cellular localization of mouse Pfcp.1 was detected in the nucleus. The results obtained by the computer program PSORT II confirmed this result which predicted the 
localization of mouse Pfcp.1 in the nucleus. We also determined the subcellular localization of the protein and its possible chromatin binding capacity. Pfcp.1 colocalizes to the chromatin.

All of the proteins associated with chromatin can be divided into two categories: histones and nonhistone chromosomal proteins. The distinction is by no means an arbitrary one, for the histones represent a well characterized group of proteins with quite unique compositions, sequence characteristics and functions. Their relative amounts and stoichiometry with respect to DNA are nearly constant throughout the eukaryotic kingdom. The nonhistone chromosomal proteins might be operationally defined as all of the other proteins isolated with chromatin. The histones are found in the somatic cells of all eukaryotic organisms, with the exception of some dinoflagellates. The common element of chromatin structure in eukaryotic somatic cells is the nucleosome and this requires a set of histones that will interact so as to form a core on which DNA can be wrapped. This kind of organization seems to be synonymous with the existence of recognizable histones. But it should be noted that not all cells, even in the higher organisms, exhibit such chromatin organization.

All histones are basic proteins, containing relatively large amounts of lysine and arginine. There is a sufficient excess of basic over acidic residues to give histones a substantial positive net charge at physiological $\mathrm{pH}$. The positive charge is distributed quite unevenly in the histone sequences. In all cases, the N-terminal region contains a high concentration of basic residues; in $\mathrm{H} 2 \mathrm{~A}$ and $\mathrm{H} 3$, there are similar domains near the $\mathrm{C}$ terminus. The lysine-rich histones (H1 and its many variants) have a very long, positively charged C-terminal domain in addition to a lysine-rich $\mathrm{N}$-terminal region. It is probable that each of these domains has both structural and functional significance. The histones have been generally conserved in evolution. The existence of multiple copies of histone genes in a given organism suggests the possibility of nonallelic variation (this may also be possible to Pfcp).

The histone variation in mouse is probably the most thoroughly studied of that in any higher organism. The mouse histone variants presently recognized fall into two main classes: those present in somatic cells, and a special set of "testes" histones found only in developing spermatocytes (Seyedin and Kistler, 1979; Zweidler, 1980; Meistrich et al., 1985).

It seems probable that the $\mathrm{N}$-terminal domains of histones play some special role in chromatin organization. If so, nuclear reactions that modify histones in these regions could be of great significance to chromatin function. As many authors have noted, maximal acetylation of these sites would markedly reduce the net positive charge and therefore DNA-binding strength of 
the N-terminal domains. That the precise location of these modifications may be important to their role in chromatin function is suggested by the fact that these lysine residues, in otherwise evolutionarily unstable domains, are highly conserved (Isenberg, 1979; Yoshioka et al., 2001). Soon after the discovery of histone acetylation, Allfrey, (1966) suggested that this modification might promote the transcription of chromatin. A great deal of evidence has come up in the following years to support this hypothesis (Loyola et al., 2001).

The specific phosphorylations of different sites in $\mathrm{H} 1$ probably play important roles in the regulation of cellular processes.

It has been argued that the histones determine the fundamental structural features of chromatin. However, it must be emphasized that chromatin is a dynamic structure, constantly changing during transcription, replication, mitosis, meiosis and DNA repair. The histones themselves undergo both partial replacement and major modification during the cell cycle. All of these processes must require the participation of innumerable other proteins in the nuclear milieu. It has long been recognized that the histones represent only a part of the protein component of chromatin. The remaining "nonhistone" proteins might be defined as those proteins other than histones that are associated with chromatin in vivo.

Therefore, researchers tend to fall back on more operational definitions, such as: "Nonhistone chromosomal proteins (NHCPs) are those, other than histones, attached to isolated chromatin." The nucleus is bounded by an envelope, which consists of three layers: an outer membrane, an inner membrane, and a proteinaceous, fibrous lamina. The envelope is pierced at many points by nuclear pores. These are large enough to allow small protein molecules to pass through, a fact taken advantage of in studies where chromatin is digested by nucleases diffused into intact nuclei. Therefore, the nucleus is to some extent open to the cytoplasm, and some proteins can presumably exchange between these compartments in vivo.

Many believe that the nucleus contains a fibrillar protein structure called the nuclear matrix. This is said to contain 10 to $20 \%$ of the total nuclear protein (Berezney and Coffey, 1975; Long et al., 1979; Lepock et al., 2001). Although the exact composition is difficult to fix, most matrix preparations seem to include some components of the lamina (the lamins) as well as specialized proteins such as topoisomerases. There is evidence that the chromatin fibers are themselves attached to both the matrix and the lamina. Bathing the chromatin and matrix is presumably a nuclear sap, a concentrated solution of proteins that associate only weakly with other components.

Some proteins will be attached to and isolated with the nucleohistone fiber only at certain stages in the cell cycle. An example is provided by the studies of Adolph (1984) comparing 
the proteins of interphase chromatin and whole metaphase chromosomes of HeLa cells. While $90 \%$ of the antigenic determinants of interphase chromatin could be identified in the metaphase chromosomes, the latter also contained a substantial number of additional proteins. On the other hand, chromatin prepared from the metaphase chromosomes seemed much more similar to that from interphase (Wray et al., 1980).

The chromatin of eukaryotic cells is an exceedingly dynamic material. It is replicated, and portions of it are continually undergoing transcription. Concomitantly, it is modified in a host of ways. Therefore, it is to be expected that among the nonhistone, chromatin-associated proteins will be found many of the enzymes involved in these processes. This is indeed the case, and a large number of such activities have been identified.

For some years, it has been recognized that significant changes in chromatin organization occur within the $5^{\prime}$-flanking (promoter) regions of genes that are activated for transcription. The appearance of nuclease hypersensitive sites (or, more precisely, regions) is a frequent aspect of these changes. More recently, it has been found that a number of such regions bind specific nonhistone proteins. These proteins are necessary co-factors for RNA polymerase II, which seems unable to recognize promoter sites in their absence. The function of these proteins has been reviewed by Dynan and Tijan (1985) and Deleu et al. (2001).

There appear to be at least two classes of "structural" nonhistone proteins associated with chromatin. The first of these is represented by those proteins that remain firmly attached to eukaryotic DNA even after extraction with very high salt, polyelectrolytes, or strong detergents. These are sometimes referred to as chromosomal "scaffold" proteins, or "residual" proteins. A second and more problematic class includes contractile and structural proteins similar to those found elsewhere in cells and tissues; i.e., actin, myosin and tubulin. The role of these latter as nonhistone proteins or even their presence in nuclei of living cells has been a matter of considerable controversy (Chan et al., 2001).

The detailed function of Pfcp in the chromatin needs to be analysed but the presence of a PHD-finger domain argues for a function in chromatin mediated transcriptional regulation. A possible step towards unravel its function may be the identification of Pfcp interacting proteins by yeast-two-hybrid analysis or fractionated isolation of different parts of the chromatin and identification of the Pfcp protein in these preparations by specific antibodies. These experiments are currently under way. 


\section{SUMMARY}

In this study, we examined the susceptibility of primordial germ cells (PGCs) to malignant transformation using a transgenic mouse model. In this model we used the simian virus 40 (SV40) large tumor antigen (LTA) fused to the promoter of germ cell alkaline phosphatase (GCAP) to specifically direct the oncogenic activity of SV40-LTA to PGCs. Human GCAP is developmentally expressed in primordial germ cells and also from the 2-cell to blastocyst stage of preimplantation development and reappears in trace amounts in the adult testis. Furthermore, GCAP is reexpressed in precancerous stages of testicular germ cell tumors (carcinoma in situ) and also in more differentiated tumors. We analyzed the regulatory sequences in the 5'-flanking region of human GCAP gene which are responsible for its expression in different testicular germ cell tumors to determine the minimal promoter region sufficient for a high and tissue specific expression of GCAP. Three independent transgenic lines were generated using a fragment of $1.7 \mathrm{~kb} 5$ 'flanking of the GCAP gene as a promoter. RT-PCR analysis showed testis specific expression of LTA in the adults of heterozygous and homozygous transgenic mice in trace amounts. Furthermore, we could detect LTA mRNA in $8.5 \mathrm{dpc}$ prenatal transgenic embryos. However, even after a period of about 20 months, no tumor was observed in any organ of these mice.

Using an "in vitro" approach of analysing differentially expressed genes in GC-1spg cells through suppression subtractive hybridization (SSH), a so far unknown gene which was found to be highly expressed in invasive GC-1spg cells was identified, we named this gene Pfcp (PHD-finger-like chromatin proteins) as the deduced protein sequence shows a domain known as "PHD-finger" like domain, known to be involved in chromatin binding. The cDNA sequence of mouse Pfcp was isolated and analyzed as well as its genomic structure. The expression pattern of mouse Pfcp and its cellular and subcellular location was determined: screening a mouse cosmid library and a genomic Southern blot showed the pattern of a gene family which consists of about four different murine Pfcp genes. Northern blot analysis showed one transcript at approximately $1.2 \mathrm{~kb}$. The expression of Pfcp in different mouse tissues is ubiquitous. The expression analysis of human PFCP showed an ubiquitous expression as well. Pfcp is localized in the nucleus and binds to chromatin structures in interphase and metaphase of the cell cycle. 


\section{REFERENCES}

Aasland, R., Gibson, T. J. and Stewart, A. F. (1995). The PHD finger: implications for chromatin-mediated transcriptional regulation. Trends Biochem. Sci. 20 (2): 56-9.

Abramczuk, J., Pan, S., Maul, G. and Knowles, B. B. (1984). Tumor induction by simian virus 40 in mice is controlled by long-term persistence of the viral genome and the immune response of the host. J. Virol. 49 (2): 540-548.

Adolph, K. W. (1984). Conservation of interphase chromatin nonhistone antigens as components of metaphase chromosomes. FEBS Lett. 165 (2): 211-215.

Affolter, M., Percival-Smith, A., Müller, M., Leupin, W. and Gehring, W. J. (1990). DNA binding properties of the purified Antennapedia homeodomain. Proc. Natl. Acad. Sci. USA. 87: 4093-4097.

Agulnik, A. I., Mitchell, M. J., Mattei, M., Borsani, G., Avner, P. A., Lerner, J. L. and Bishop, C. E. (1994). A novel X gene with a widely transcribed Y-linked homologue escapes X-inactivation in mouse and human. Hum. Mol. Genet. 3: 879-884.

Allfrey, V. G. (1966). Structural modifications of histones and their possible role in the regulation of ribonucleic acid synthesis. Proc. Can. Cancer Conf. 6: 313-35.

Atkin, N. and Baker, M. (1987). Abnormal chromosomes including small metacentrics in 14 ovarian cancers. Cancer Genet. Cytogenet. 26: 355-361.

Ausubel, F. M. (1992). Current protocols in molecular biology. Wiley \& Sons Inc, New York.

Behringer, R. R., Peschon, J. J., Messing, A., Gartside, C. L., Hauschka, S. D., Palmiter, R. D. and Brinster, R. L. (1988). Heart and bone tumors in transgenic mice. Proc. Natl. Acad. Sci. USA. $85: 2648-2652$.

Berezney, R. and Coffey, D. S. (1975). In advances in enzyme regulation (Weber, G.). 14: 63100. Pergamon Press, Oxford. 
Berg, J. M. (1990). Zinc fingers and other metal-binding domains. J. Biol. Chem. 265: 65136516.

Bergstrom, R., Adami, H. O., Mohner, M., Zatonski, W., Storm, H., Ekbom, A., Treth, S., Teppo, L., Akre, O. and Hakulinen, T. (1996). Increase in testicular cancer in six european countries: a birth cohort phenomenon. J. Natl. Cancer Inst. 88: 727-733.

Bosl, G. J., Ilson, D. H., Rodriguez, E., Motzer, R. J., Reuter, V. E. and Chaganti, R. S. (1994). Clinical relevance of the i(12p) marker chromosome in germ cell tumors. J. Natl. Cancer Inst. 86 (5): 349-355.

Bosse, P., Bernex, F., De Sepulveda, P., Salaun, P. and Panthier, J. J. (1997). Multiple neuroendocrine tumors in transgenic mice induced by c-kit-SV40 T antigen fusion genes. Oncogene, 14: 2661-2670.

Brinster, P., Chen, H. Y., Messing, A., Van Dyke, T., Levine, A. J. and Palmiter, R. D. (1984). Transgenic mice harboring SV40 T-antigen genes develop characteristic brain tumors. Cell, 37: 367-379.

Chaganti, R. S. K., Murty, V. V. V. S. and Bosl, G. J. (1996). Molecular genetics of male germ cell tumors. In: N. J. Vogelzang, W. U. Shipley, P. T. Scardino and D. S. Coffey. Comprehensive Textbook of Genitourinary Oncology, 932-940. Williams and Wilkins, Baltimore.

Chaganti, R. S. K. and Houldsworth, J. (1998). The cytogenetic theory of the pathogenesis of human adult male germ cell tumors. Acta Pathol. Microbiol. Immunol. Scand. 106: 80-84.

Chaganti, R. S. K. and Houldsworth, J. (2000). Genetics and biology of adult human male germ cell tumors. Cancer Res. 60: 1475-148.

Chan, H. M. and La Thangue, N. B. (2001). p300/CBP proteins: HATs for transcriptional bridges and scaffolds. J. Cell Sci. 114(Pt 13): 2363-73. 
Clarke, A. R., Purdie, C. A., Harrison, D. J., Morris, R. G., Bird, C. C., Hooper, M. L. and Wyllie, A. H. (1993). Thymocyte apoptosis induced by p53-dependent and independent pathways. Nature, 362: 849-852.

Cresta, C. M., Masters, J. R. W. and Hickman, J. A. (1996). Hypersensitivity of human testicular tumours to etoposide-induced apoptosis is associated with functional p53 and a high Bax: Bcl-2 ratio. Cancer Res. 56: 1834-1841.

Damjanov, I. (1991). Pathobiology of human germ cell neoplasia. 123: 1-19, Springer-Verlag, Berlin.

Deleu, L., Pujol, A., Nuesch, J. P. and Rommelaere, J. (2001). Inhibition of transcriptionregulating properties of nonstructural protein 1 (NS1) of parvovirus minute virus of mice by a dominant-negative mutant form of NS1. J. Gen. Virol. 82(Pt 8): 1929-34.

Desplan, C., Theis, J. and O'Farrell, P. H. (1988). The sequence specificity of homeodomainDNA interaction. Cell, 54: 1081-1090.

Dynan, W. S. and Tijan, R. (1985). Control of eukaryotic messenger RNA synthesis by sequence-specific DNA-binding proteins. Nature, 316 (6031): 774-778.

Einhorn, L. H. (1990). Treatment of testicular cancer: a new and improved model. J. Clin. Oncol. 8: 1777-1781.

Feinberg, A. P. and Vogelstein, B. (1983). A technique for radiolabelling DNA restriction endonuclease fragments of high specific activity. Anal. Biochem. 137: 266-267.

Fisher, D. E. (1994). Apoptosis in cancer therapy: crossing the threshold. Cell. 78: 539-542.

Freyd, G., Kim, S. K. and Horvitz, H. R. (1990). Novel cysteine-rich motif and homeodomain in the product of the Caenorhabditis elegans cell lineage gene lin-ll. Nature, 344: 876-879. 
Hahnel, A. C., Rappolee, D. A., Millan, J. L., Manes, T., Ziomek, C. A., Theodosiou, N. G., Werb, Z., Pedersen, R. A., Schultz, G. A. (1990) : Two alkaline phosphatase genes are expressed during early development in the mouse embryo. Development, 110: 555-564.

Hamburger, A. W. (1977). Primary bioassay of human tumor stem cells. Science, 197: 461463.

Han, K., Levine, M. S. and Manley, J. (1989). Synergistic activation and repression of transcription by Drosophila homeobox proteins. Cell, 6: 573-583.

Hanahan, D. (1985). Heritable formation of pancreatic beta-cell tumours in transgenic mice expressing recombinant insulin/simian virus 40 oncogenes. Nature, 315: 115-22.

Hargis, B. J. and Malkiel, S. J. (1979). Nat. Cancer Inst. 63: 965-967.

Harris, C. C. (1996). Structure and function of the p53 tumour suppressor gene: clues for rational cancer therapeutic strategies. J. Natl. Cancer Inst. 88: 1442-1452.

Heimdal, K., Lothe, L. A., Lystad, S., Holm, R., Fossa, S. D. and Borresen, A. L. (1993). No germline TP53 mutations detected in familial and bilateral testicular cancer. Genes Chromosomes Cancer, 6: 92-97.

Hoey, T. and Levin, M. (1988). Divergent homeobox proteins recognize similar DNA sequences in Drosophila. Nature, 332: 858-861.

Hoey, T. and Levine, M. (1988). Homeobox proteins as sequence specific transcription factors. Cell, 55: 537-540.

Hofmann, M. C., Jeltsch, W., Brescher, J. and Walt, H. (1989). Alkaline phosphatase isoenzymes in human testicular germ cell tumors, three related cell lines and their precancerous stage. Cancer Res. 49: 4696-4700.

Hofmann, M. C., Narisawa, S., Hess, R. A. and Millan, J. L. (1992). Immortalization of germ cells and somatic testicular cells using the SV40 large T antigen. Exp. Cell Res. 201: 417-435. 
Hofmann, M. C. and Millan, J. L. (1993). Developmental expression of alkaline phosphatase genes; reexpression in germ cell tumours and in vitro immortalized germ cells. Eur. Urol. 23: 38-45.

Houldsworth, J., Reuter, V., Bosl, G. and Chaganti, R. (1997). Aberrant expression of cyclin D2 is an early event in human male germ cell tumorigenesis. Cell Growth Differ. 8: 293-299.

Huddart, R. A, Titley, J., Robertson, D., Williams, G. T., Horwich, A. and Cooper, C. S. (1995). Programmed cell death in response to chematherapeutic agents in human germ cell tumour lines. Eur. J. Cancer, 31A: 739-746.

Ingraham, H. A., Flynn, S. E., Voss, J. W., Albert, V. R., Kapiloff, M. S., Wilson, L. and Rosenfeld, M. G. (1990). The POU-specific domain of Pit-1 is essential for sequence-specific, high affinity DNA binding and DNA-dependent Pit-1-Pit-1 interactions. Cell, 61: 1021-1033.

Isenberg, I. (1979). Histones. Ann. Rev. Biochem. 48: 159-191.

Jain, V. K. and Magrath, I. T. (1991). A chemiluminescent assay for quantitation of betagalactosidase in the femtogram range: application to quantitation of beta-galactosidase in lacZ-transfected cells. Anal Biochem. 199 (1): 119-24.

Jiang, J., Hoey, T. and Levine, M. (1991). Autoregulation of a segmentation gene in Drosophila: combinatorial interaction of the even-skipped homeobox protein with a distal enhancer element. Genes Devel. 5: 265-277.

Karlsson, O., Thor, S., Norberg, T., Ohlsson, H. and Edlund, T. (1990). Insulin gene enhancer binding protein 1sl-1 is a member of a novel class of proteins containing both a homeo-and a Cys-His domain. Nature, 344: 879-882.

Kogan, S. C., Doherty, M. and Gitschier, J. (1987). An improved method for prenatal diagnosis of genetic diseases by analysis of amplified DNA sequences. New England J. Med. 317: 985-990. 
Koshida, K. and Wahren, B. (1990). Placental-like alkaline phosphatase in seminoma. Urol. Res. 18: 87-92.

Koshida, K., Nishino, A., Yamamoto, H., Uchibayashi, T., Naito, K., Hisazumi, H., Hirano, K., Hayashi, Y., Wahren, B. and Andersson, L. (1991). The role of alkaline phosphatase isoenzymes as tumor markers for testicular germ cell tumors. Urol. 146: 57-60.

Laird, P. W., Zijderwald, A., Linders, K., Rudnicki, M. A., Jaenisch, R. and Berns, A. (1991). Simplified mammalian DNA isolation procedure. Nucleic Acids Res. 19: 4293.

Laughon, A. (1991). DNA binding specificity of homeodomains. Biochemistry, 30: 1135711367.

Lepock, J. R., Frey, H. E., Heynen, M. L., Senisterra, G. A. and Warters, R. L. (2001). The nuclear matrix is a thermolabile cellular structure. Cell Stress Chaperones, 6 (2): 136-47.

Lewis, A. M. and Look, J. L. (1985). Science. 227: 15-20.

Lichter, P., Cremer, T., Borden, J., Manuelidis, L., Ward, D. C. (1988) : Delineation of individual human chromosomes in metaphase and interphase cells by in situ suppression hybridization using recombinant DNA libraries. Hum. Genet. 80: 224-234.

Lin, L. F., Doherty, D. H., Lile, J. D., Bektesh, S. and Collins, F. (1993). GDNF: a glial cell line-derived neurotrophic factor for midbrain dopaminergic neurons. Science, 260: 11301132.

Long, B. H., Huang, C. Y. and Pogo, A. U. (1979). Cell, 18: 1079-1090.

Loveland, K. L. and Schlatt, S. (1997). Stem cell factor and c-kit in the mammalian testis: lessons originating from Mother Nature's gene knockouts. J. Endocrinol. 153: 337-344.

Lowe, S. W., Ruley, H. E., Jacks, T. and Housman, D. E. (1993). p53-Dependent apoptosis modulates the cytotoxicity of anticancer agents. Cell, 74: 957-967. 
Lowry, O. H., Rosebrough, N. J., Farr, A. L. and Randall, R. J. (1951) : Protein measurement with folin phenol reagent. J. Biol. Chem. 193: 265-275.

Loyola, A., Le Roy, G., Wang, Y. H. and Reinlerg, D. (2001). Reconstitution of recombinant chromatin establishes a requirement for histone-tail modifications during chromatin assembly and transcription. Genes Dev. 15 (21): 2837-51.

Luisi, B. (1992). Zinc standard for economy. Nature, 356: 379-380.

Mann, K. (1990). Tumormarker beim Hodenkarzinom. Urol. Ausg. A. 29: 77-86.

Masters, J. R. W., Osborne, E. J., Walker, M. C. and Parris, C. N. (1993). Hypersensitivity of human testis tumour cell lines to chemotherapeutic drugs. Int. J. Cancer, 53: 340-346.

Mazo, A. M., Huang, D., Mozer, B. A. and Dawid, I. B. (1990). The trithorax gene, a transacting regulator of the bithorax complex in Drosophila, encodes a protein with zinc-binding domains. Proc. Natl. Acad. Sci. USA. 87: 2112-2116.

Meistrich, M. L., Bucci, L. R., Trrostle-Weige, P. K. and Broch, W. A. (1985). Develop. Biol. 112: $230-240$.

Meng, X., Lindahl, M., Hyvönen, M., Parvinen, M., De Rooij, D. G., Michael, W. H., Raatikainen-Ahokas, A., Sainio, K., Rauvala, H., Lakso, M., Pichel, J., Westphal, H., Saarma, M., and Sariola, H. (2000). Regulation of cell fate decision of undifferentiated spermatogonia by GDNF. Science, 287: 148-149.

Meng, X., De Rooij, D. G., Westerdahl, K., Saarma, M. and Sariola, H. (2001). Promotion of seminomatous tumors by targeted overexpression of glial cell line-derived neurotrophic factor in mouse testis. Cancer Research, 61: 3267-3271.

Millan, J. L. (1992). Alkaline phosphatase as a reporter of cancerous transformation. Clin. Chim. Acta. 209: 123-129. 
Millan, J. L. and Fishman, W. H. (1995). Biology of human alkaline phosphatase with special reference to cancer. Clin. Lab. Sci. 32: 1-39.

Mitsumori, K., and Elwell, M. R. (1988). Proliferative lesions in the male reproductive system of F344 rats and B6C3F1 mice: incidence and classification. Environ. Health Perspect. 77: $11-21$.

Motzer, R. J., Amsterdam, A., Prieto, V., Murty, V. V. V. S., Mazumadar, M., Sheinfeld, J., Bosl, D. F., Chaganti, R. S. K. and Reuter, V. E. (1998). Teratoma with malignant transformation: diverse malignant histologies arising in men with germ cell tumors. J. Urol. 159: 133-138.

Nakayama, H., Nishiyama, H., Higuchi, T., Kaneko, Y., Fukumoto, M. and Fujita, J. (1996). Change in cyclin D2 mRNA expression during murine testis development detected by fragmented cDNA subtraction method. Dev. Growth Differ. 38: 141-151.

Narisawa, S., Hofmann, M. C., Ziomek, C. A. and Millan, J. L. (1992). Embryonic alkaline phosphatase is expressed at M-phase in spermatogenic lineage of the mouse. Development, 116: $159-165$.

Nayernia, K., Abbas, A., Klaproth, S. and Engel, W. (1998). Haploid male germ cells show no susceptibility to transformation by simian virus large tumor antigen in transgenic mice. Cell Biol. Int. 22: 437-43.

Peng, H. Q., Hogg, D., Malkin, D., Bailey, D., Gallie, B. L., Bulbul, M., Jewett, M., Buchanan, J. and Goss, P. E. (1993). Mutations of the p53 gene do not occur in testis cancer. Cancer Res. 53 (15): 3574-3578.

Porsch, P., Merkelbach, S., Gehlen, J. and Fladung, M. (1993). The nonradioactive chloramphenicol acetyltransferase-enzyme-linked immunoabsorbent assay test is suited for promoter activity studies in plant protoplasts. Anal. Biochem. 211: 113-116. 
Said, K., Jaqart, T., Montgelard, C., Sonjaya, H., Helal, A. N. and Britton-Davidian, J. (1986) Robertsonian house mouse population in Tunisia : a karyological and biochemical study. Genetica. 68: 151-156.

Saiki, R. K., Scharf, S., Faloon, F., Mullis, K. B., Horn, G. T., Ehrlich, H. A. and Arnheim, N. (1985). Enzymatic amplification of beta-globin genomic sequences and restriction site analysis for diagnosis sickle cell anemia. Science, 230: 1350-1354.

Sambrook, J., Fritsch, E. F. and Maniatis, T. (1989). In Molecular Cloning : A Laboratory Manual, 2nd ed. Cold Spring Harbor, New York : Cold Spring Harbor Laboratory Press.

Schär, B. K., Otto, V. O. and Hänsler, E. (1997). Cancer Res. 57: 3841-3846.

Schindler, U., Beckmann, H. and Cashmore, A. R. (1993). HAT3.1, a novel Arabidopsis homeodomain protein containing a conserved cysteine-rich region. Plant, 4: 137-150.

Schwartz, D., Goldfinger, N., Kam, Z. and Rotter, V. (1999). p53 controls low DNA damagedependent premeiotic checkpoint and facilitates DNA repair during spermatogenesis. Cell Growth Differ. 10: 665-675.

Scott, M. P., Tamkun, J. W. and Hartzell 11l, G. W. (1989). The structure and function of the homeodomain. Biochem. Biophys. Acta. 989: 25-48.

Seyedin, S. M. and Kistler, W. S. (1979). Biochemistry, 18: 1376-1379.

Skakkebaek, N. (1972). Possible carcinoma in situ in the testis. Lancet. 2: 516-517.

Skakkebaek, N., Berthelsen, J., Giwercman, A. and Müller, J. (1987). Carcinoma in situ of the testis and possible origin from gonocytes and precurser of all types of germ cell tumours except spermatocytoma. Int. J. Andr. 10: 19-28.

Skakkebaek, N. E., Rajpert-de Meyts, E., Jorgensen, N., Carlsen, E., Meidahl Petersen, P., Giwercman, A., Andersen, A-G., Kold Jensen, T., Andersson, A-M. and Müller, J. (1998). Germ cell cancer and disorders of spermatogenesis: an environmental connection? Acta Pathol. Microbiol. Immunol. Scand. 106: 3-12. 
Southern, E. M. (1975). Detection of specific sequences among DNA fragments separated by gel electrophoresis. J. Mol. Biol. 98: 503-517.

Stern, S. A., Tanaka, M. and Herr, W. (1989). The Oct-1 homeodomain directs formation of a multiprotein-DNA complex with the HSV transactivator VP16. Nature, 341: 624-630.

Stevens, L. C. (1970). Experimental production of testicular teratomas in mice of strains 129, A/He, and their F1 Hybrids. Nat. Cancer Inst. 44: 923-929.

Strohmeyer, T., Reissmann, P., Cordon-Cardo, C., Hartmann, M., Ackermann, R. and Slamon, D. (1991). Correlation between retinoblastoma gene expression and differentiation in human testicular tumors. Proc. Natl. Acad. Sci. USA. 88 (15): 6662-6666.

Tascou, S., Nayernia, K., Samani, A., Schmidtke, J., Vogel, T., Engel, W. and Burfeind, P. (2000). Immortalization of murine male germ cells at a discrete stage of differentiation by a novel promoter-based selection strategy. Biol. Reprod. 63: 1555-1561.

Tascou, S., Nayernia, K., Uedelhoven, J., Böhm, D., Jalal, R., Ahmed, M., Engel, W. and Burfeind, P. (2001). Isolation and characterization of differentially expressed genes in invasive and non-invasive immortalized murine male germ cells in vitro. Int. J. Oncol. 18: $567-574$.

Thomas, H., Hanby, A. M., Smith, R. A., Hagger, P., Patel, K., Raikunalia, B., Camplejohn, R. S. and Balkwill, F. R. (1996). An inbred colony of oncogene transgenic mice: diversity of tumors and potential as a therapeutic models. Br. J. Cancer, 73: 65-72.

Thompson, K. A., Wang, B., Argraves, W. S., Giancotti, F. G., Schranck, D. P. and Ruoslahti, E. (1994). BR140, A novel zinc-finger protein with homology to the TAF250 subunit of TFIID. Biochem. Biophys. Res. Commun. 198: 1143-1152.

Tollerud, D. J., Blattner, W. A., Fraser, M. C., Brown, L. M., Pottern, L., Shapiro, E., Kirkemo, A., Shawker, T. H., Javadpour, N. and O'Connell, K. (1985). Familial testicular cancer and urogenital developmental abnormalities. Cancer, 55: 1849-1854. 
Tooze, J. (1981). Molecular Biology of Tumor Viruses Pt2 Cold Spring Harbor Laboratory, New York.

Treisman, J., Harris, E. and Desplan, C. (1991). The paired box encodes a second DNAbinding domain in the paired homeodomain protein. Genes Devel. 5: 594-604.

Ulbright, T. M. (1993). Germ cell neoplasms of the testis. Am. J. Surg. Pathol. 17: 10751091.

Van Hoof, V. O. and De Broe, M. E. (1994). Interpretation and clinical significance of alkaline phosphatase isoenzyme patterns. Clin. Lab. Sci. 31: 197-293.

Veeramachaneni, D. N. R., and Vandewoude, S. (1999). Interstitial-cell tumour and germ-cell tumour with carcinoma in situ in rabbit testes. Int. J. Androl., 22: 97-101.

Viglietto, G., Dolci, S., Bruni, P., Baldassarre, G., Chiariotti, L., Melillo, R. M., Salvatore, G., Chiappetta, G., Sferratore, F., Fusco, A., and Santoro, M. (2000). Glial cell line-derived neurotrophic factor and neurturin can act as paracrine growth factors stimulating DNA synthesis of Ret-expressing spermatogonia. Int. J. Oncol. 16: 689-694.

Vincent, J.-P., Kassis, J. A. and O'Farrell, P. H. (1990). A synthetic homeodomain binding site acts as a cell type specific, promoters specific enhancer in, Drosophila embryos. EMBO J. 9: 2573-2578.

Vos, A. M., Oosterhuis, J. W., de Jong, B., Buist, J. and Koops, H. S. (1990). Cytogenetics of carcinoma in situ of the testis. Cancer Genet. Cytogenet. 46: 75-81.

Voss, J. W., Wilson, L. and Rosenfeld, M. G. (1991). POU- domain proteins Pit-1 and Oct-1 interact to form a heteromeric complex and can cooperate to induce expression of the prolactin promoter. Genes Devel. 5: 1309-1320.

Wada, N. and Yang Chou, J. (1993). Characterization of upstream activation elements essential for the expression of germ cell alkaline phosphatase in human choriocarcinoma cells. Biol. Chem. 268: 14003-14010. 
Weinberg, R. A. (1995). The retinoblastoma protein and cell cycle control. Cell. 81: 323-330.

Wikenheiser, K. A. and Whitesett, J. A. (1997). Tumor progression and cellular differentiation of pulmonary adenocarcinomas in SV40 large T antigen transgenic mice. Am. J. Respir Cell Mol. Biol. 16: 713-723.

Wray, V. P., Elgin, S. C. R. and Wray, W. (1980). Nucleic Acids Res. 8: 4155-4163.

Wu, J., Ellison, J., Salido, E., Yen, P., Mohandas, T. and Shapiro, L. J. (1994). Isolation and characterization of XE169, a novel human gene that escapes X-inactivation. Hum. Mol. Genet. 3: 153-160.

Yoshioka, H., Shirayoshi, Y. and Oshimura, M. (2001). A novel in vitro system for analyzing parental allele-specific histone acetylation in genomic imprinting. J. Hum. Genet. 46 (11): 626-32.

Zörnig, M., Klett, C., Loav, H., Hameister, H. and Winking H. (1995). Establishment of permanent wild-mouse cell lines with readily identifiable marker chromosomes. Cytogenet. Cell Genet. 74: 37-40.

Zweidler, A. (1980). Develop. Biochem. 15: 47-56.

Zwingman, T., Erickson, R. P., Boyer, T. and Ao, A. (1993). Transcription of the sexdetermining region genes Sry and Zfy in the mouse preimplantation embryo. Proc. Natl. Acad. Sci. USA. 90 (3): 814-7. 


\section{PUBLICATIONS}

Zahran, W. M., El-shahawy, G. A., Gabry, M. S. and Ahmed, M. (1995). Histological changes induced by the trematode cynodiplostomum azimi on the lymph organs of the albino rat (rattus norvegicus). Proceeding of the first international scientific conference (Science and Development) Cairo. 707-729.

El-Shahawi, G. A., Zahran, W. M., Gabry, M. S. and Ahmed, M. (1995). Haematological changes in the infected white rat (rattus norvegicus) by the trematode cynodiplostomum azimi. J. Egypt. Ger. Soc. Zool. (Invertebrate Zoology and Parasitology). 18: 1-18.

Tascou, S., Nayernia, K., Uedelhoven, J., Böhm, D., Jalal, R., Ahmed, M., Engel, W. and Burfeind, P. (2001). Isolation and characterization of differentially expressed genes in invasive and non-invasive immortalized murine male germ cells in vitro. International Journal of Oncology. 18: 567-574. 


\section{ACKNOWLEDGEMENT}

I would like to express my gratitude to my thesis advisor Prof. Dr. W. Engel for his excellent scientific supervision and encouragement.

I also wish to express my thanks to Dr. R. Trappe for his great help throughout this study.

I would like to thank Dr. P. Burfeind for his help during my study.

I would like to thank Dr. K. Nayernia, Dr. M. Kämper, Dr. S. Tascou and D. Boinska.

I thank all my colleagues at the Institut of Human Genetics.

I also wish to express my great thanks to my parents, my husband and my country for all what they have done for me. 


\section{CURRICULUM VITAE}

Manal Bayomi Mahmoud Ahmed, born on 12.02.1966 in El-Minia, Egypt

1983-1987 Department of Zoology, Faculty of Science,

El-Minia University, El-Minia, Egypt

1987

B. Sc. in Zoology

1994

M. Sc in Zoology

1995-1996

Department of Zoology,

El-Minia University

$1997-2001$

Ph. D study at Institute of Human Genetics,

Georg-August-University, Göttingen, Germany 